In cooperation with the California State Water Resources Control Board A product of the California Groundwater Ambient Monitoring and Assessment (GAMA) Program

\title{
Status and Understanding of Groundwater Quality in the Northern San Joaquin Basin, 2005: California GAMA Priority Basin Project
}

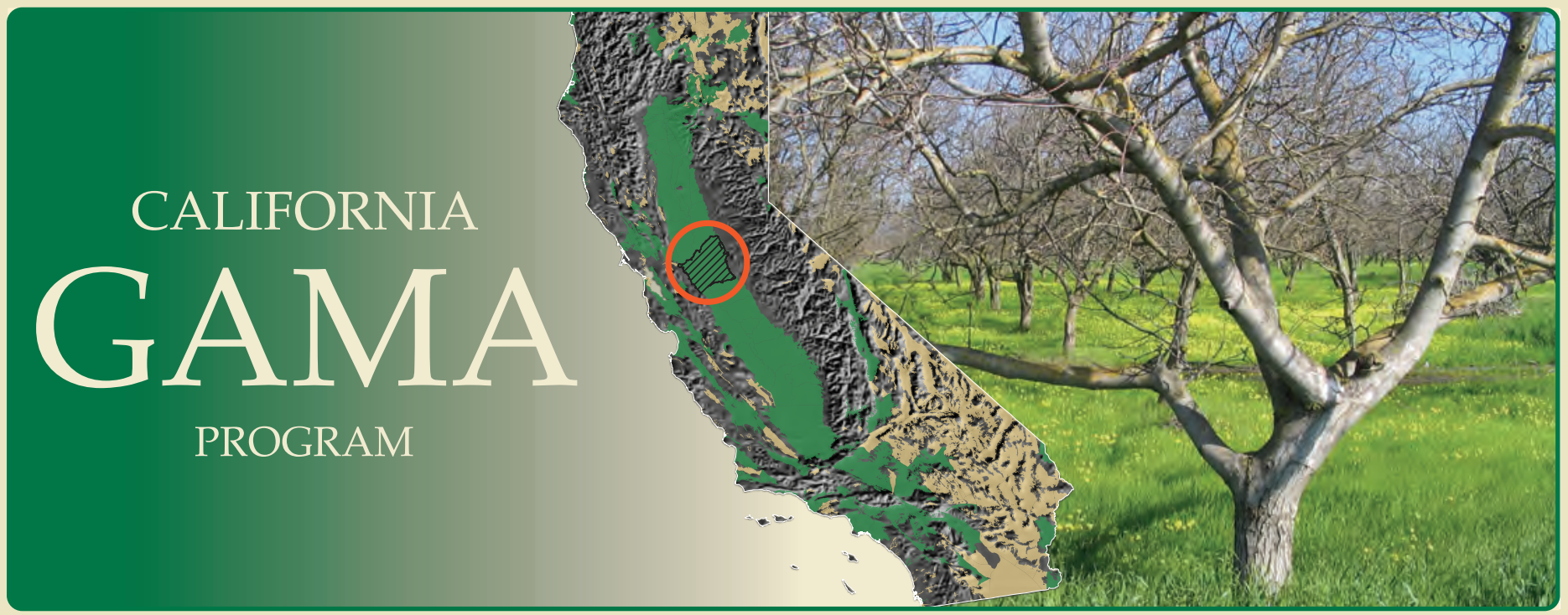

Scientific Investigations Report 2010-5175 
Front Cover Map: Groundwater basins categorized by sampling priority. Location of groundwater basin boundaries from California Department of Water Resources (DWR, 2003).

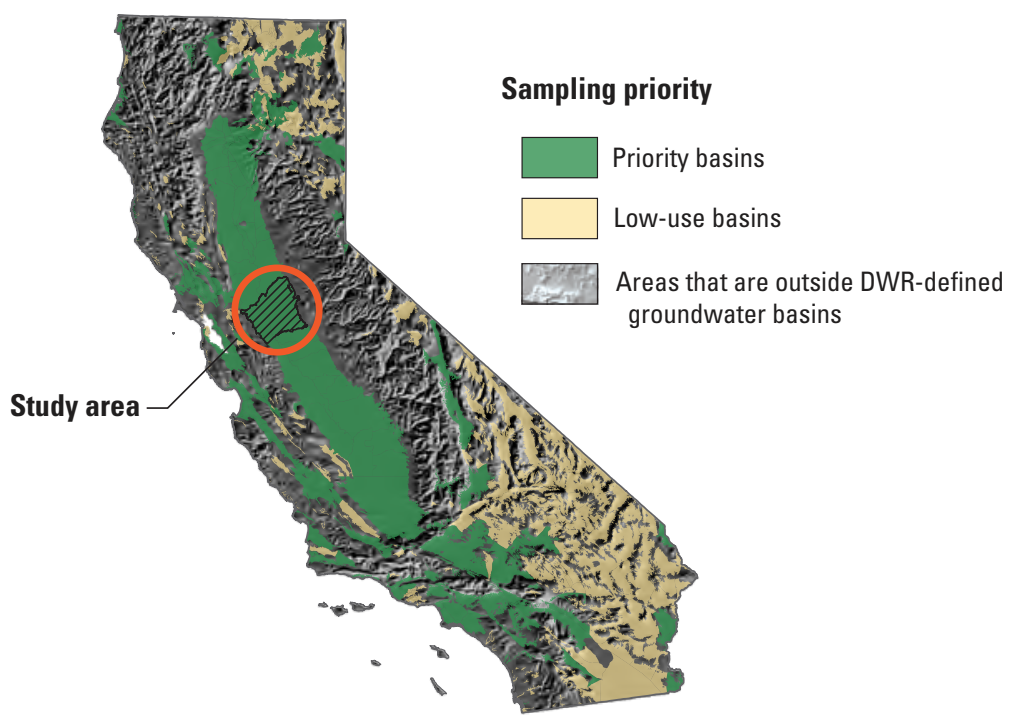

\section{Cover photographs:}

Front cover: Almond orchard in San Joaquin County, California. (Photograph taken by Cathy Munday, U.S. Geological Survey)

Back cover: Preparing to sample a well in the Tracy study area, San Joaquin County, California. (Photograph taken by Steve Schmitt, U.S. Geological Survey) 


\section{Status and Understanding of Groundwater Quality in the Northern San Joaquin Basin, 2005: California GAMA Priority Basin Project}

By George L. Bennett, V, Miranda S. Fram, Kenneth Belitz, and Bryant C. Jurgens

A product of the California Groundwater Ambient Monitoring and Assessment (GAMA) Program

Scientific Investigations Report 2010-5175 


\title{
U.S. Department of the Interior \\ KEN SALAZAR, Secretary
}

\section{U.S. Geological Survey \\ Marcia K. McNutt, Director}

\section{U.S. Geological Survey, Reston, Virginia: 2010}

\author{
For more information on the USGS - the Federal source for science about the Earth, its natural and living resources, \\ natural hazards, and the environment, visit http://www.usgs.gov or call 1-888-ASK-USGS \\ For an overview of USGS information products, including maps, imagery, and publications, \\ visit http://www.usgs.gov/pubprod \\ To order this and other USGS information products, visit http://store.usgs.gov
}

\begin{abstract}
Any use of trade, product, or firm names is for descriptive purposes only and does not imply endorsement by the U.S. Government.

Although this report is in the public domain, permission must be secured from the individual copyright owners to reproduce any copyrighted materials contained within this report.
\end{abstract}

Suggested citation:

Bennett, G.L., V, Fram, M.S., Belitz, Kenneth, and Jurgens, B.C., 2010, Status and understanding of groundwater quality in the northern San Joaquin Basin, 2005: California GAMA Priority Basin Project: U.S. Geological Survey Scientific Investigations Report 2010-5175, 82 p. 


\section{Contents}

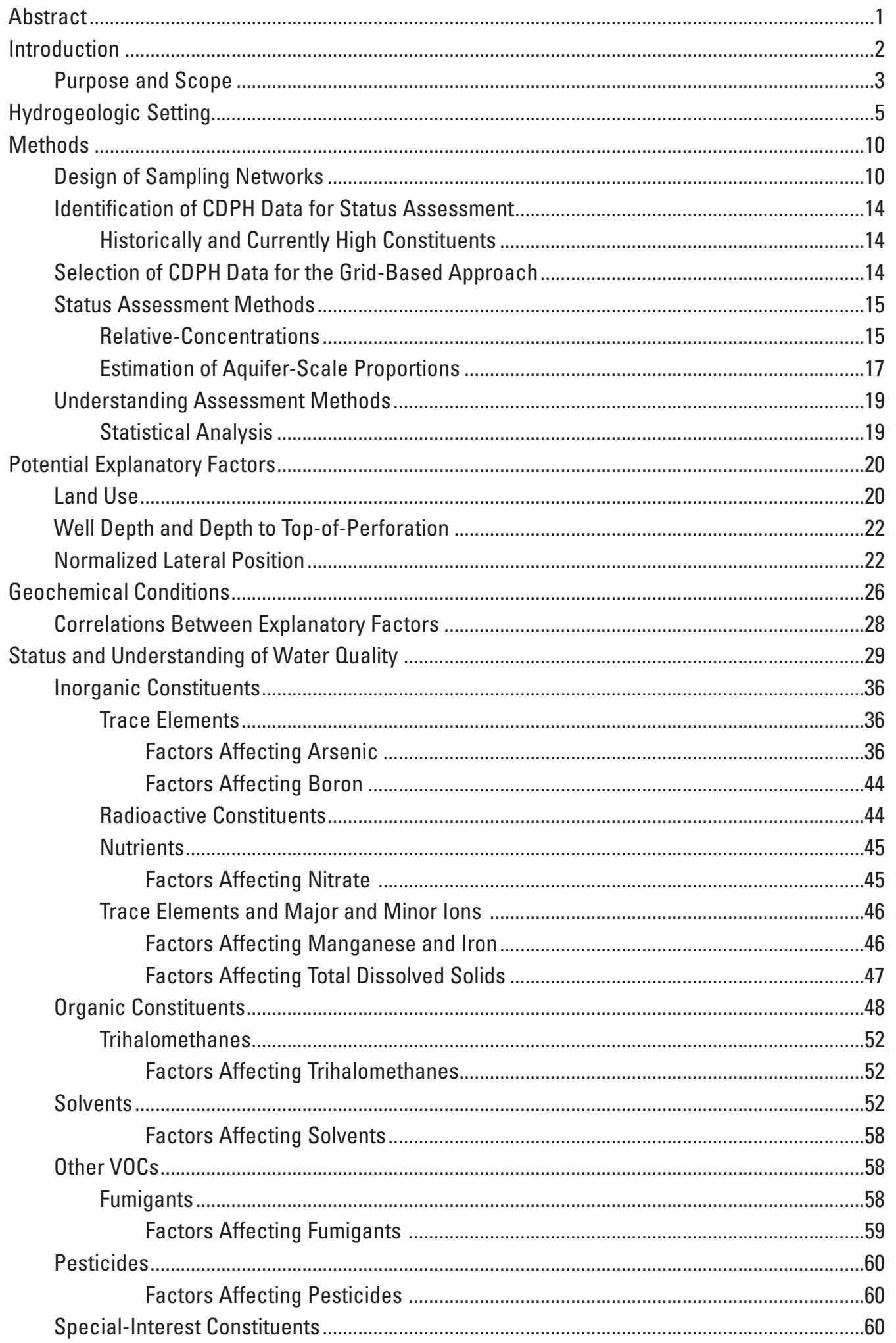




\section{Contents-Continued}

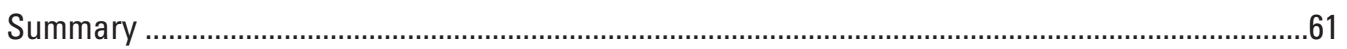

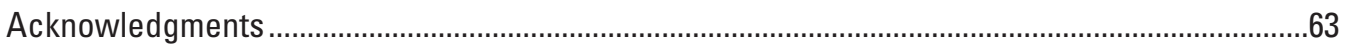

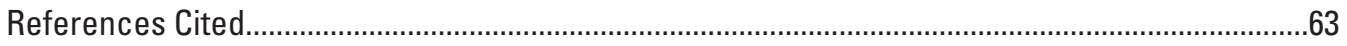

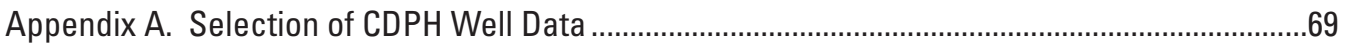

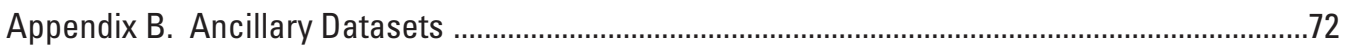

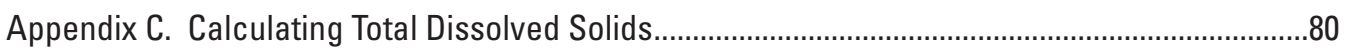

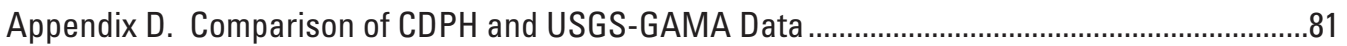

\section{Figures}

Figure 1. Map showing location of Northern San Joaquin Basin Groundwater Ambient Monitoring and Assessment (GAMA) study unit and California hydrogeologic

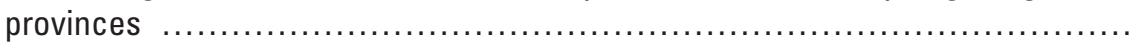

Figure 2. Map showing geographic features and study areas of the Northern San Joaquin Basin Groundwater Ambient Monitoring and Assessment (GAMA) study unit

Figure 3. Map showing geologic formations, and areal distribution of grid and understanding wells, in the Northern San Joaquin Basin Groundwater Ambient Monitoring and Assessment (GAMA) study unit

Figure 4. Conceptual model of the aquifer system for the Northern San Joaquin Basin Groundwater Ambient Monitoring and Assessment (GAMA) study unit

Figure 5. Map showing land use of the Northern San Joaquin Basin Groundwater Ambient Monitoring and Assessment (GAMA) study unit ....

Figure 6. Map showing study area grids, grid and understanding wells sampled, and California Department of Public Health wells used for supplemental data on inorganic constituents, Northern San Joaquin Basin Groundwater Ambient

Monitoring and Assessment (GAMA) study unit

Figure 7. Ternary diagrams showing proportions of urban, agricultural, and natural land use, Northern San Joaquin Groundwater Ambient Monitoring and Assessment (GAMA) study unit

Figure 8. Boxplots showing well depths, depths to top-of-perforation, and perforation lengths for grid and understanding wells, Northern San Joaquin Basin Groundwater Ambient Monitoring and Assessment (GAMA) study unit

Figure 9. Map and graph showing distribution of wells plotted on visualization of normalized lateral positions and across the range of normalized lateral positions, Northern San Joaquin Basin Groundwater Ambient Monitoring and Assessment (GAMA) study unit....

Figure 10. Boxplots of classified groundwater age related to depth to top-of-perforation, well depth, and normalized lateral position, Northern San Joaquin Basin Groundwater Ambient Monitoring and Assessment (GAMA) study unit

Figure 11. Profile showing relation of classified groundwater age to normalized lateral position and depth of perforated interval of wells, Northern San Joaquin Basin Groundwater Ambient Monitoring and Assessment (GAMA) study unit 


\section{Figures-Continued}

Figure 12. Map of redox conditions in grid and understanding wells, Northern San Joaquin Basin Groundwater Ambient Monitoring and Assessment (GAMA)

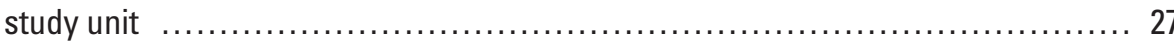

Figure 13. Boxplot of classified redox category to normalized lateral position, Northern San Joaquin Basin Groundwater Ambient Monitoring and Assessment (GAMA) study unit

Figure 14. Graph showing maximum relative-concentration in grid wells for constituents detected by type of constituent, Northern San Joaquin Basin Groundwater Ambient Monitoring and Assessment (GAMA) study unit ...

Figure 15. Graphs showing relative-concentrations of trace elements and nutrients with health-based benchmarks and maximum relative-concentrations greater than 0.5 in grid wells, and major and minor elements with aesthetic benchmarks and maximum relative-concentrations greater than 0.5 in grid wells, Northern San Joaquin Basin Groundwater Ambient Monitoring and Assessment (GAMA) study unit

Figure 16. Maps showing relative-concentrations of selected inorganic constituents for USGS-grid and USGS-understanding wells, and relative-concentrations from the most recent inorganic constituent data point from the "prior period" (January 1, 2001-April 21, 2004) for CDPH wells, Northern San Joaquin Basin

Groundwater Ambient Monitoring and Assessment (GAMA) study unit.

Figure 17. Graphs showing relation of arsenic to well depth and $\mathrm{pH}$ and redox condition, Northern San Joaquin Basin Groundwater Ambient Monitoring and Assessment (GAMA) study unit

Figure 18. Boxplots showing nitrate plus nitrite concentrations grouped by geochemical (redox) conditions, Northern San Joaquin Basin Groundwater Ambient Monitoring and Assessment (GAMA) study unit

Figure 19. Boxplots showing manganese concentrations grouped by geochemical (redox) conditions, Northern San Joaquin Basin Groundwater Ambient Monitoring and Assessment (GAMA) study unit

Figure 20. Graphs showing relation of total dissolved solids concentrations to normalized lateral position within the Cosumnes, Eastern San Joaquin, Upland, and Tracy study areas, Northern San Joaquin Basin Groundwater Ambient Monitoring and Assessment (GAMA) study unit

Figure 21. Graph showing detection frequency and maximum relative-concentration for organic and special-interest constituents detected in grid wells, Northern San Joaquin Basin Groundwater Ambient Monitoring and Assessment (GAMA) study unit

Figure 22. Graphs showing relative-concentrations and detection frequencies of selected VOC and special-interest constituents in grid wells, Northern San Joaquin Basin Groundwater Ambient Monitoring and Assessment (GAMA) study unit

Figure 23. Graphs showing relative-concentrations and detection frequencies of selected fumigant and pesticide constituents in grid wells, Northern San Joaquin Basin Groundwater Ambient Monitoring and Assessment (GAMA) study unit 


\section{Figures-Continued}

Figure 24. Maps showing relative-concentrations of selected organic constituents for USGS-grid and USGS-understanding wells representative of the primary aquifer and from the most recent analysis (January 1, 2001-April 21, 2004) for CDPH wells, Northern San Joaquin Groundwater Ambient Monitoring and Assessment (GAMA) study unit.

Figure 25. Graph showing pesticide, solvent, total trihalomethane (TTHM), and fumigant detection frequencies grouped by groundwater-age classification, Northern San Joaquin Basin Groundwater Ambient Monitoring and Assessment (GAMA) study unit

Figure 26. Graph showing relation between detections of total trihalomethanes (TTHMs) and depth to top-of-perforation and percentage of urban land use in $500-\mathrm{m}$ buffer areas surrounding wells for USGS-grid and USGS-understanding well samples, Northern San Joaquin Basin Groundwater Ambient Monitoring and Assessment (GAMA) study unit. ...

Figure 27. Graph showing relation between detections of solvents and depth to top-of-perforation and percentage of urban land use in 500-m buffer areas surrounding wells for USGS-grid and USGS-understanding well samples, Northern San Joaquin Basin Groundwater Ambient Monitoring and Assessment (GAMA) study unit.

Figure 28. Graph showing relation between detections of fumigants and depth to top-of-perforation and percentage of agricultural land use in 500-meter buffer areas surrounding wells for USGS-grid and USGS-understanding well samples, Northern San Joaquin Basin Groundwater Ambient Monitoring and Assessment (GAMA) study unit....

Figure 29. Graph showing relation between detection of pesticides and depth to top-of-perforation and percentage of agricultural land use in 500-m buffer areas surrounding wells for USGS-grid and USGS-understanding well samples, Northern San Joaquin Basin Groundwater Ambient Monitoring and Assessment (GAMA) study unit

\section{Appendix Figures}

Figure A1. Map showing identifiers and locations of grid and understanding wells sampled during December 2004-February 2005, and grid wells at which data for inorganic constituents from the California Department of Public Health were used, Northern San Joaquin Basin Groundwater Ambient Monitoring and Assessment (GAMA) study unit ....

Figure D1. Graph of paired inorganic concentrations from wells sampled by the Groundwater Ambient Monitoring and Assessment (GAMA) Program between December 2004 and February 2005 and the most recent available analysis in the California Department of Health Services for the same wells, Northern San Joaquin Basin Groundwater Ambient Monitoring and Assessment (GAMA) study unit

Figure D2. Trilinear diagram comparing water types in grid wells with water types in all wells in the California Department of Public Health (CDPH) database that have a charge imbalance of less than 10 percent, Northern San Joaquin Basin Groundwater Ambient Monitoring and Assessment (GAMA) study unit 


\section{Tables}

Table 1. Analytes and numbers of wells sampled for different analytical schedules, Northern San Joaquin Basin Groundwater Ambient Monitoring and Assessment (GAMA) study unit.

Table 2. Comparison of number of compounds and median method detection levels or laboratory reporting levels by type of constituent for data stored in the California Department of Public Health (CDPH) database and data collected by the Northern San Joaquin Basin Groundwater Ambient Monitoring and Assessment (GAMA) study unit.

Table 3. Constituents in California Department of Public Health (CDPH) wells at high concentrations from January 10, 1984-April 21, 2004 (the period of record prior to the 3-year period used in the status assessment), Northern San Joaquin Basin Groundwater Ambient Monitoring and Assessment (GAMA) study unit ..... 15

Table 4. Inorganic constituents (including the special-interest constituent perchlorate), benchmarks, and number of grid wells per constituent, Northern San Joaquin Basin Groundwater Ambient Monitoring and Assessment (GAMA) study unit ..... 16

Table 5. Benchmark type and value for constituents included in the assessment of status of groundwater quality in the Northern San Joaquin Basin Groundwater Ambient Monitoring and Assessment (GAMA) study unit

Table 6. Results of Wilcoxon tests for differences in values of selected water-quality constituents and potential explanatory factors between young and old groundwater-age classification, wells with depths to top-of-perforation less than 200 feet and those equal to or greater than 200 feet, and wells with oxic conditions versus those with anoxic conditions, Northern San Joaquin Basin Groundwater Ambient Monitoring and Assessment (GAMA) study unit

Table 7. Results of non-parametric (Spearman's rho method) analysis of correlations in grid wells between selected potential explanatory factors, Northern San Joaquin Basin Groundwater Ambient Monitoring and Assessment (GAMA) study unit

Table 8. Number of constituents analyzed and detected by health-based benchmark type and constituent type, Northern San Joaquin Basin Groundwater Ambient Monitoring and Assessment (GAMA) study unit

Table 9. Current aquifer-scale proportions computed using raw detection frequency, spatially weighted, and grid-based approaches for constituents detected at concentrations greater than water-quality benchmarks during the period of available data (January 10, 1984-April 21, 2004) from the California Department of Health Services database or detected in greater than 10 percent of the wells sampled, Northern San Joaquin Basin Groundwater Ambient Monitoring and Assessment (GAMA) study unit

Table 10. Aquifer-scale proportions for constituent classes, Northern San Joaquin Basin Groundwater Ambient Monitoring and Assessment (GAMA) study unit

Table 11. Summary of Spearman's rho correlation analysis between selected water-quality constituents and potential explanatory factors, Northern San Joaquin Basin Groundwater Ambient Monitoring and Assessment (GAMA) study unit 


\section{Appendix Tables}

Table A1. Nomenclature for wells sampled by USGS or selected from the CDPH database for the Northern San Joaquin Basin Groundwater Ambient Monitoring and Assessment (GAMA) study unit.

Table B1. Land-use classification for wells sampled by USGS or selected from CDPH database for the Northern San Joaquin Basin Groundwater Ambient Monitoring and Assessment (GAMA) study unit.

Table B2. Well construction and normalized lateral position information for wells sampled by USGS or selected from the CDPH database for the Northern San Joaquin Basin Groundwater Ambient Monitoring and Assessment (GAMA) study unit.

Table B3. Summary of tritium data from samples of unfiltered water and classification of samples into young and old categories, Northern San Joaquin Basin Groundwater Ambient Monitoring and Assessment (GAMA) study unit.

Table B4. Concentrations of constituents used to classify geochemical (redox) conditions in groundwater, Northern San Joaquin Basin Groundwater Ambient

Monitoring and Assessment (GAMA) study unit.

\section{Conversion Factors, Datum, and Abbreviations and Acronyms}

\section{Conversion Factors}

\begin{tabular}{lcl}
\hline \multicolumn{1}{c}{ Multiply } & \multicolumn{1}{c}{ By } & \multicolumn{1}{c}{ To obtain } \\
\hline inch (in.) & 2.54 & centimeter $(\mathrm{cm})$ \\
inch (in.) & 25.4 & millimeter $(\mathrm{mm})$ \\
foot (ft) & 0.3048 & meter $(\mathrm{m})$ \\
mile (mi) & 1.609 & kilometer $(\mathrm{km})$ \\
square mile (mi2) & 2.590 & square kilometer $(\mathrm{km} 2)$ \\
picocurie per liter $(\mathrm{pCi} / \mathrm{L})$ & 0.037 & becquerel per liter $(\mathrm{Bq} / \mathrm{L})$ \\
\hline
\end{tabular}

\section{SI to Inch/Pound}

\begin{tabular}{lccc} 
& Multiply & By & To obtain \\
\hline meter $(\mathrm{m})$ & 3.281 & foot $(\mathrm{ft})$ & \\
\hline
\end{tabular}

Temperature in degrees Celsius $\left({ }^{\circ} \mathrm{C}\right)$ may be converted to degrees Fahrenheit $\left({ }^{\circ} \mathrm{F}\right)$ as follows:

$$
{ }^{\circ} \mathrm{F}=\left(1.8 x^{\circ} \mathrm{C}\right)+32 .
$$

Temperature in degrees Fahrenheit $\left({ }^{\circ} \mathrm{F}\right)$ may be converted to degrees Celsius $\left({ }^{\circ} \mathrm{C}\right)$ as follows:

$$
{ }^{\circ} \mathrm{C}=\left({ }^{\circ} \mathrm{F}-32\right) / 1.8 \text {. }
$$

Specific conductance is given in microsiemens per centimeter at 25 degrees Celsius $(\mu \mathrm{S} / \mathrm{cm}$ at $\left.25^{\circ} \mathrm{C}\right)$.

Concentrations of chemical constituents in water are given either in milligrams per liter (mg/L) or micrograms per liter ( $\mu \mathrm{g} / \mathrm{L})$. One milligram per liter is equivalent to 1 part per million ( $\mathrm{ppm})$; 1 microgram per liter is equivalent to 1 part per billion $(p p b) ; 1$ nanogram per liter $(\mathrm{ng} / \mathrm{L})$ is equivalent to 1 part per trillion (ppt); 1 per mil (\%) is equivalent to 1 part per thousand. 


\section{Conversion Factors and Datum-Continued}

\section{Datum}

Horizontal coordinate information is referenced to the North American Datum of 1983 (NAD 83).

Vertical coordinate information is referenced to the North American Vertical Datum of 1988 (NAVD 88).

\section{Abbreviations and Acronyms}

$\begin{array}{ll}\text { AB } & \text { Assembly Bill (through the California State Assembly) } \\ \text { BLS } & \text { below land surface } \\ \text { AL-US } & \text { U.S. Environmental Protection Agency action level } \\ \text { COS } & \text { Cosumnes study area grid well } \\ \text { DO } & \text { dissolved oxygen } \\ \text { E } & \text { estimated or having a higher degree of uncertainty } \\ \text { ESJ } & \text { Eastern San Joaquin study area grid well } \\ \text { ESJFP } & \text { Eastern San Joaquin study area flow-path well } \\ \text { GAMA } & \text { Groundwater Ambient Monitoring and Assessment Program } \\ \text { HAL-US } & \text { U.S. Environmental Protection Agency lifetime health advisory level } \\ \text { LRL } & \text { laboratory reporting level } \\ \text { MCL-CA } & \text { California Department of Public Health maximum contaminant level } \\ \text { MCL-US } & \text { U.S. Environmental Protection Agency maximum contaminant level } \\ \text { MDL } & \text { method detection limit } \\ \text { NSJ-OPC } & \text { Quaternary/Plio-Pleistocene age semiconsolidated deposits } \\ \text { NL } & \text { notification level } \\ \text { REDOX } & \text { reduction-oxidation } \\ \text { RPD } & \text { relative percent difference } \\ \text { RSD5 } & \text { U.S. Environmental Protection Agency risk-specific dose at a risk factor of } 10^{-5} \\ \text { SMCL } & \text { secondary maximum contaminant level } \\ \text { TEAP } & \text { terminal electron acceptor processes } \\ \text { TRCY } & \text { Tracy study area grid well } \\ \text { TRCYFP } & \text { Tracy study area flow-path well } \\ \text { TU } & \text { tritium unit } \\ \text { US } & \text { United States }\end{array}$




\section{Conversion Factors and Datum-Continued}

\section{Organizations}

$\begin{array}{ll}\text { CDPH } & \begin{array}{l}\text { California Department of Public Health (was California Department of Health } \\ \text { Services prior to July 1, 2007) } \\ \text { CDWR }\end{array} \\ \text { California Department of Water Resources } \\ \text { LLNL } & \text { Lawrence Livermore National Laboratory } \\ \text { NAWQA } & \text { National Water Quality Assessment (USGS) } \\ \text { SWRCB } & \text { State Water Resources Control Board (California) } \\ \text { TDS } & \text { total dissolved solids } \\ \text { USEPA } & \text { U.S. Environmental Protection Agency } \\ \text { USGS } & \text { U.S. Geological Survey }\end{array}$

\section{Selected Chemical Names}

$\begin{array}{ll}\text { DBCP } & \text { 1,2-dibromo-3-chloropropane } \\ \text { EDB } & \text { 1,2-dibromomethane } \\ { }^{3} \mathrm{H} & \text { tritium } \\ \text { HTO } & \text { tritiated water } \\ \text { MTBE } & \text { methyl-tert-butyl-ether } \\ \text { NDMA } & N \text {-nitrosodimethylamine } \\ \text { PCE } & \text { tetrachloroethene } \\ 1,2,3-T C P & 1,2,3 \text {-trichloropropane } \\ \text { TDS } & \text { total dissolved solids } \\ \text { THM } & \text { trihalomethane } \\ \text { TTHM } & \text { total trihalomethanes } \\ \text { VOC } & \text { volatile organic compound }\end{array}$




\title{
Status and Understanding of Groundwater Quality in the Northern San Joaquin Basin, 2005: California GAMA Priority Basin Project
}

\author{
By George L. Bennett V, Miranda S. Fram, Kenneth Belitz, and Bryant C. Jurgens
}

\section{Abstract}

Groundwater quality in the 2,079 square mile Northern San Joaquin Basin (Northern San Joaquin) study unit was investigated from December 2004 through February 2005 as part of the Priority Basin Project of the Groundwater Ambient Monitoring and Assessment (GAMA) Program. The GAMA Priority Basin Project was developed in response to the Groundwater Quality Monitoring Act of 2001 that was passed by the State of California and is being conducted by the California State Water Resources Control Board in collaboration with the U.S. Geological Survey and the Lawrence Livermore National Laboratory.

The Northern San Joaquin study unit was the third study unit to be designed and sampled as part of the Priority Basin Project. Results of the study provide a spatially unbiased assessment of the quality of raw (untreated) groundwater, as well as a statistically consistent basis for comparing water quality throughout California. Samples were collected from 61 wells in parts of Alameda, Amador, Calaveras, Contra Costa, San Joaquin, and Stanislaus Counties; 51 of the wells were selected using a spatially distributed, randomized grid-based approach to provide statistical representation of the study area (grid wells), and 10 of the wells were sampled to increase spatial density and provide additional information for the evaluation of water chemistry in the study unit (understanding/flowpath wells).

The primary aquifer systems (hereinafter, primary aquifers) assessed in this study are defined by the depth intervals of the wells in the California Department of Public Health database for each study unit. The quality of groundwater in shallow or deep water-bearing zones may differ from quality of groundwater in the primary aquifers; shallow groundwater may be more vulnerable to contamination from the surface. Two types of assessments were made: (1) status, assessment of the current quality of the groundwater resource; and (2) understanding, identification of the natural and human factors affecting groundwater quality.

Relative-concentrations (sample concentrations divided by benchmark concentrations) were used for evaluating groundwater quality for those constituents that have Federal or California regulatory or non-regulatory benchmarks for drinking-water quality. Benchmarks used in this study were either health-based (regulatory and non-regulatory) or aesthetic based (non-regulatory). For inorganic constituents, relative-concentrations were classified as high (equal to or greater than 1.0), indicating relative-concentrations greater than benchmarks; moderate (equal to or greater than 0.5 , and less than 1.0); or, low (less than 0.5 ). For organic and specialinterest constituents [1,2,3-trichloropropane (1,2,3-TCP), $\mathrm{N}$-nitrosodimethylamine (NDMA), and perchlorate], relativeconcentrations were classified as high (equal to or greater than 1.0); moderate (equal to or greater than 0.1 and less than 1.0); or, low (less than 0.1).

Aquifer-scale proportion was used as the primary metric in the status assessment for groundwater quality. High aquiferscale proportion is defined as the percentage of the primary aquifer with relative-concentrations greater than 1.0; moderate and low aquifer-scale proportions are defined as the percentage of the primary aquifer with moderate and low relativeconcentrations, respectively. The methods used to calculate aquifer-scale proportions are based on an equal-area grid; thus, the proportions are areal rather than volumetric. Two statistical approaches - grid-based, which used one value per grid cell, and spatially weighted, which used the full datasetwere used to calculate aquifer-scale proportions for individual constituents and classes of constituents. The spatially weighted estimates of high aquifer-scale proportions were within the 90-percent confidence intervals of the grid-based estimates in all cases. The understanding assessment used statistical correlations between constituent relative-concentrations and values of selected explanatory factors to identify those factors potentially affecting constituent relative-concentrations and occurrence. Individual constituents detected at high relative-concentrations or those detected at low relative-concentrations in substantial proportions of the aquifer (greater than 10 percent) were evaluated statistically in relation to selected explanatory factors. Explanatory factors evaluated in this report were land use, well depth, depth to top-of-perforation, lateral and vertical position within the flow system, groundwater age, and geochemical conditions. 
The status assessment for inorganic constituents showed that relative-concentrations (one or more) were high, relative to health-based benchmarks, in 13 percent of the primary aquifer, moderate in 29 percent, and low in 58 percent. High relative-concentrations of inorganic constituents in the primary aquifer reflected high proportions of arsenic (high relative-concentrations in 9.4 percent of the aquifer) and boron (7.6 percent). Inorganic constituents with aesthetic-based benchmarks [non-regulatory secondary maximum contaminant levels (SMCLs)], manganese, iron, total dissolved solids (TDS), chloride, and sulfate, were detected at high relativeconcentrations in $34,11,5.8,3.9$, and 2 percent of the primary aquifer, respectively. SMCLs are benchmarks given to constituents with technical properties that can make drinking water undesirable with respect to taste, staining, or scaling at high relative-concentrations.

The status assessment for organic constituents showed that relative-concentrations (one or more) were high in 2.7 percent, moderate in 6.9 percent, and low in 90 percent of the primary aquifer of the Northern San Joaquin study unit. High relative-concentrations of organic constituents in the primary aquifer reflected high relative-concentrations of the discontinued soil fumigant 1,2-dibromo-3-chloropropane (DBCP, 2.7 percent of the primary aquifer). Maximum relative-concentrations were equal to or greater than 0.1 and (or) a detection frequency greater than 10 percent for five organic constituents: chloroform, DBCP, methyl tert-butyl ether (MTBE), simazine, and tetrachloroethylene (PCE).

The understanding assessment for inorganic constituents showed that groundwater age, normalized lateral position, and redox conditions were the most significant explanatory factors related to inorganic constituent relative-concentrations. Groundwater age was shown to be associated with relative-concentrations of arsenic, gross alpha radioactivity, and total dissolved solid (TDS). High and moderate relativeconcentrations of arsenic, iron, and manganese primarily were associated with geochemical conditions. Relativeconcentrations of arsenic were high in oxygen-rich high-pH waters and in anoxic waters. High relative-concentrations of iron and manganese were most often associated with lowoxygen anoxic waters. Normalized lateral position, a sampled well's position in the Northern San Joaquin study unit relative to the basin center and basin edge, was shown to be associated with arsenic, nitrate, and TDS relative-concentrations. High and moderate relative-concentrations of arsenic and TDS were found more frequently closer to the valley trough (basin center), where relative-concentrations of nitrate tended to decrease, than in wells near the valley margins (basin edges).

The understanding assessment for organic constituents showed that groundwater age, well depth, and land use within 500 meters of the sampled well were the most significant factors affecting organic constituent relative-concentrations. Trihalomethanes, fumigants, pesticides, and solvents were all shown to have higher relative-concentrations in young groundwater than in old groundwater. Fumigant and pesticide relative-concentrations were related to well perforation depth, with wells with shallow depths to top-of-perforation having higher constituent relative-concentrations than those with deeper depths to top-of-perforation. Detections of trihalomethanes and solvents were positively associated with urban land use and negatively associated with agricultural land use. Fumigant detections were strongly correlated with a specific agricultural land use-orchards and vineyards.

\section{Introduction}

Groundwater comprises nearly one-half of the water used for public supply in California (Hutson and others, 2004). To assess the quality of ambient groundwater in aquifers used for public and domestic drinking-water supply and to establish a baseline groundwater quality-monitoring program, the State Water Resources Control Board (SWRCB), in collaboration with the U.S. Geological Survey (USGS) and Lawrence Livermore National Laboratory (LLNL), implemented the Groundwater Ambient Monitoring and Assessment (GAMA) Program (http://www.waterboards.ca.gov/gama). The GAMA Program currently consists of three projects: GAMA Priority Basin Project, conducted by the USGS (http://ca.water.usgs. gov/gama/); GAMA Domestic Well Project, conducted by the SWRCB; and GAMA Special Studies, conducted by LLNL. On a statewide basis, the Priority Basins Project focused primarily on the deep portion of the groundwater resource and the SWRCB Domestic Well Project generally focused on the shallow aquifer systems.

The SWRCB initiated the GAMA Program in response to Legislative mandates (Supplemental Report of the 1999 Budget Act 1999-00 Fiscal Year; and the GAMA Priority Basin project in response to the Groundwater Quality Monitoring Act of 2001 \{Sections 10780-10782.3 of the California Water Code, Assembly Bill 599\}. The GAMA Priority Basin Project is a comprehensive assessment of statewide groundwater quality designed to help better understand and identify risks to groundwater resources and to increase the availability of information about groundwater quality to the public. For the Priority Basin Project, the USGS, in collaboration with the SWRCB, developed a monitoring plan to assess groundwater basins through the direct sampling of groundwater and other statistically reliable sampling approaches (Belitz and others, 2003; California State Water Resources Control Board, 2003). Additional partners in the Priority Basin Assessment include the California Department of Public Health (CDPH), California Department of Pesticide Regulation (CDPR), California Department of Water Resources (CDWR), and local water agencies and well owners. 
The range of hydrologic, geologic, and climatic conditions that exist in California must be considered in an assessment of groundwater quality. Belitz and others (2003) partitioned the State into 10 hydrogeologic provinces, each with distinctive hydrologic, geologic, and climatic characteristics (fig. 1). All these hydrogeologic provinces include groundwater basins and subbasins designated by the CDWR (California Department of Water Resources, 2003). Groundwater basins generally consist of relatively permeable, unconsolidated deposits of alluvial or volcanic origin. Eighty percent of California's approximately 16,000 active and standby drinking water wells listed in the statewide database maintained by the $\mathrm{CDPH}$ (hereinafter referred to as CDPH wells) are located in designated groundwater basins within these hydrologic provinces. Groundwater basins and subbasins were prioritized for sampling on the basis of the number of drinking-water wells, with secondary consideration given to municipal groundwater use, agricultural pumping, the number of historic leaking underground fuel tanks, and registered pesticide applications (Belitz, and others, 2003). The 116 priority basins, plus additional areas outside defined groundwater basins, include about 95 percent of drinking-water wells in California.

\section{Purpose and Scope}

The GAMA Priority Basins Project is comprised of three types of water-quality assessments in each study unit-(1) Status: assessment of the current quality of the groundwater resource, (2) Understanding: identification of the natural and human factors affecting groundwater quality, and (3) Trends: detection of changes in groundwater quality (Kulongoski and Belitz, 2004). The purpose of the GAMA status assessments is to provide a statistically robust characterization of raw (untreated) groundwater quality in the part of the aquifer system used for drinking-water supply (Belitz and others, 2003). The statistically robust design also allows for comparison between basins and for synthesis of results at regional and statewide scales.

The purpose of this report is to present results of the status and understanding assessments done in the Northern San Joaquin Basin study unit. This report is one in a series of published and planned USGS Scientific Investigation Reports presenting the status and understanding of current waterquality conditions in GAMA study units. Tabulated USGS data from the initial USGS-GAMA groundwater sampling efforts in the Northern San Joaquin Basin study unit are available in Bennett and others, 2006. Tabulated USGS data from several other GAMA study units and are available as USGS Data Series Reports. Planned subsequent reports will address changes or trends in water-quality across time.
The status assessment in this report includes interpretation of water-quality data from 51 wells in the Northern San Joaquin Basin selected for sampling by USGS within spatially distributed grid cells across the study units; hereinafter, referred to as USGS-grid wells. Eighty-two percent of these wells are CDPH drinking-water wells, and perforation intervals in the remaining wells are similar to those in drinking-water wells in the area. Samples were collected from wells for analysis of dissolved anthropogenic constituents, such as volatile organic compounds (VOCs) and pesticides, and naturally occurring dissolved constituents, such as major ions and trace elements. Water-quality data from the CDPH database also were used to supplement data collected by USGS for the GAMA Program. The primary aquifer systems (hereinafter, primary aquifers) are defined by the depth intervals of the wells listed in the CDPH database for each study unit. The quality of groundwater in shallow or deep water-bearing zones may differ from that in the primary aquifers; shallow groundwater may be more vulnerable to contamination from the surface.

For the purposes of providing context, the water-quality data discussed in this report are compared to California and Federal drinking-water regulatory and non-regulatory benchmarks for treated drinking water. The assessments in this report are intended to characterize the quality of raw groundwater resources in the study unit, not the treated drinking water delivered to consumers by water purveyors. This study does not attempt to evaluate the quality of water delivered to consumers; after withdrawal from the ground, water typically is treated, disinfected, and (or) blended with other waters to maintain acceptable water quality. Regulatory benchmarks apply to treated water that is delivered to the consumer, not to raw groundwater.

The understanding assessment in this report was based on data from the 51 USGS-grid wells and 10 additional wells sampled by USGS for the purpose of understanding (hereinafter, referred to as USGS-understanding wells). Potential explanatory factors examined included land use, well depth, depth to top-of-perforation, position in the groundwater-flow system, groundwater age, and geochemical condition. This list of potential explanatory factors is not exhaustive; however, a comprehensive analysis of all possible explanatory factors is beyond the scope of this report.

Data for all constituents in samples collected by the USGS for the GAMA Program (hereinafter, USGS-GAMA sampling) in the Northern San Joaquin Basin study unit, details of sample collection, analysis, and quality-assurance procedures for the Northern San Joaquin Basin study unit are described by Bennett and others (2006). This report describes methods used in design of the sampling network, identification of CDPH data for use in the status assessment, estimation of aquifer proportions, analysis of ancillary datasets, classification of groundwater-age, and statistical and graphical approaches used in assessment of water-quality data. 


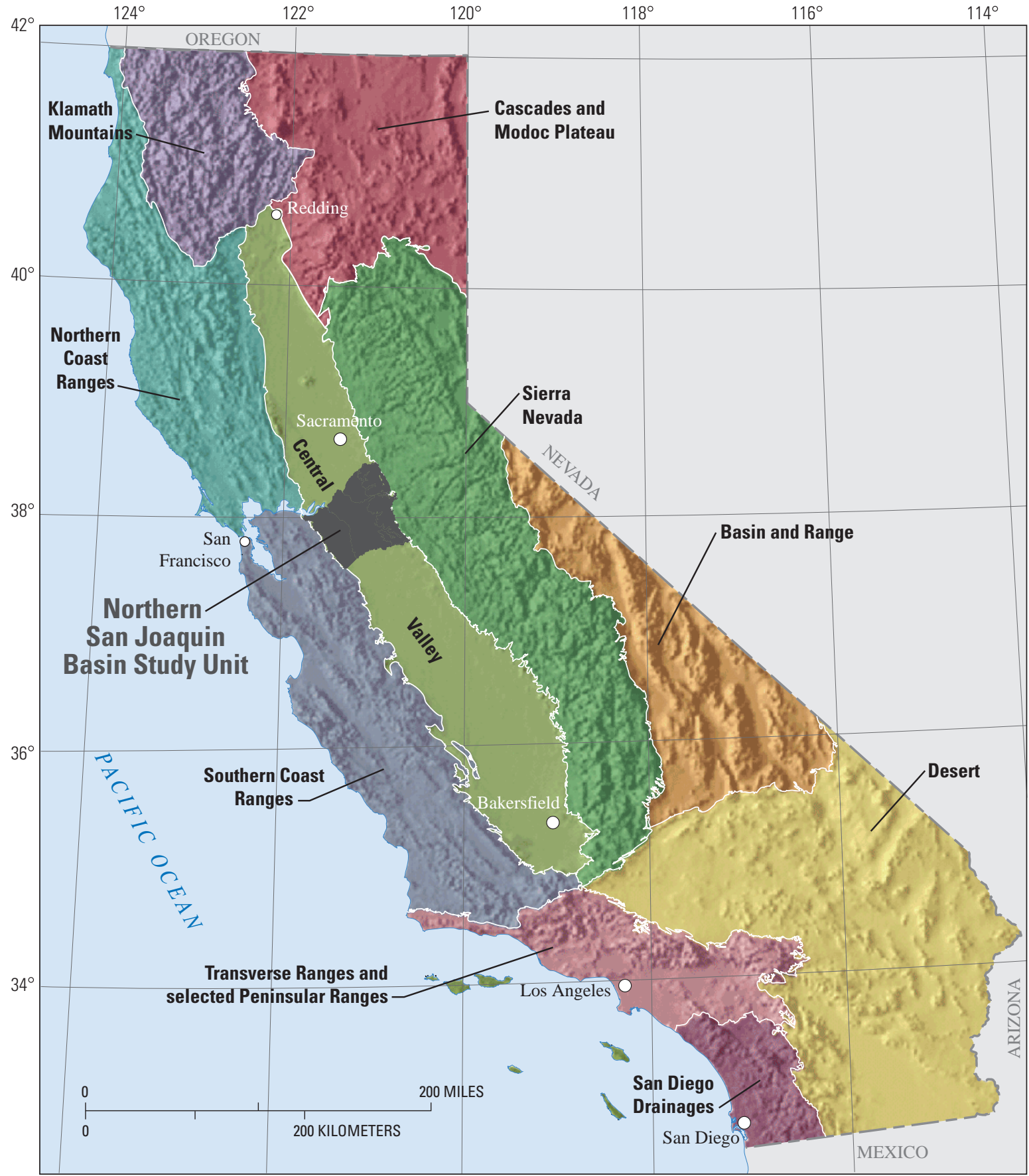

Shaded relief derived from U.S. Geological Survey

Provinces from Belitz and others (2003) National Elevation Dataset, 2006

Albers Equal Area Conic Projection

North American Datum of 1983 (NAD 83)

Figure 1. Location of Northern San Joaquin Basin Groundwater Ambient Monitoring and Assessment (GAMA) study unit and California hydrogeologic provinces (modified from Belitz and others, 2003). 


\section{Hydrogeologic Setting}

The Northern San Joaquin Basin study unit lies within the Central Valley hydrogeologic province described by Belitz and others (2003) and contains three CDWR San Joaquin Valley groundwater subbasins: Cosumnes, Eastern San Joaquin, and Tracy (California Department of Water Resources, 2003) (fig. 2). The study unit is bounded by the Coast Ranges to the west, the Sierra Nevada to the east, the Cosumnes, Mokelumne, and San Joaquin Rivers to the north, and Stanislaus County to the south.

The Northern San Joaquin Basin study unit is divided into four separate study areas: the Cosumnes (COS), Eastern San Joaquin (ESJ), and Uplands (NSJ-QPC) study areas on the east side of the San Joaquin Valley, and the Tracy study area (TRCY) on the west side (fig. 2). The exterior boundaries of the Cosumnes, Eastern San Joaquin, and Tracy study areas correspond to the CDWR groundwater subbasins of the same names. However, the Quaternary/Plio-Pleistocene-age semiconsolidated (QPC) deposits (Jennings, 1977) in upland areas (east of these subbasins) differ from the CDWR subbasins, so the study area was designated as the Uplands study area.

The Northern San Joaquin Basin study unit has a Mediterranean climate, with summers that are hot and dry, and winters that are cool and moist. Average rainfall across the study unit ranges from $11 \mathrm{in}$. in the southern and western parts of the study unit to $15 \mathrm{in}$. in the eastern to northeastern parts of the study unit (California Department of Water Resources, 2006a, 2006b, and 2006c).

Runoff from the Sierra Nevada sustains flow in rivers and streams that drain the east side of the Northern San Joaquin Basin study unit. The Stanislaus, Calaveras, Mokelumne, and Cosumnes Rivers and several smaller streams flow across the Uplands, Cosumnes, and Eastern San Joaquin study areas into the San Joaquin River (fig. 2), which flows north into the Sacramento-San Joaquin Delta and San Francisco Bay estuary. Much of the Tracy study area north of the city of Tracy and the Eastern San Joaquin study area northwest of the city of Stockton are within the boundaries of the Delta. Flows in the rivers and sloughs in the Delta are strongly affected by the tidal prism flowing through the San Francisco Bay. Flows also are affected by pumping of water from the southern end of the Delta, just northwest of Tracy, into the California Aqueduct and the Delta-Mendota Canal.

Aquifers within the study unit tapped for drinking-water supply are composed of a mix of unconsolidated alluvial-fan deposits, deeper consolidated volcanic deposits, and peat. Alluvial-fan deposits range in age from late-Pliocene to
Quaternary and are composed of multiple sediment sequences linked to repeated episodes of glaciation in the Sierra Nevada (Davis and Hall, 1959; Weissmann and others, 2002, 2004, 2005; Burow and others, 2004) (fig. 3). Alluvial-fan deposits contain interlayered lenses of gravel, sand, silt, and clay deposited by rivers draining the Sierra Nevada. A volcanic deposit, the Mehrten Formation, located about 1,000 ft below land surface in the Stockton area and at shallower depths to the east, separates overlying alluvial-fan deposits from deeper marine deposits that contain saline water in most parts of the study unit (Marchand and Allwardt, 1981; Page, 1986; Izbicki and others, 2008). The high percentage of black andesitic fragments in the Mehrten Formation deposits often help distinguish it from overlying formations. Within the boundaries of the Sacramento-San Joaquin Delta, sediments from the Sierra Nevada and Coast Ranges that accumulated within marsh stands that contain a large volume of organic matter have formed thick peat soils. These organic soils, as much as $60-\mathrm{ft}$ thick in some areas, are highly productive in terms of agriculture but are prone to subsidence (California Department of Water Resources, 1993; Ingebritsen and others, 2000). Beneath the organic soil of the Delta lies the Tulare Formation, an alluvial deposit derived during the Pleistocene from the unglaciated Coast Ranges (Hotchkiss and Balding, 1971; Bertoldi and others, 1991; California Department of Water Resources, 2006c). The source materials within the Coast Ranges for the sediments that make up the Tulare Formation include the Franciscan Formation and Cretaceous and Tertiary age marine deposits (Hotchkiss and Balding, 1971).

Primary sources of groundwater recharge in the study unit are percolation of precipitation, irrigation and urban return flows, reservoirs, and rivers (Burow and others, 2004; Phillips and others, 2007). Surface water draining from the Sierra Nevada, which is stored in reservoirs and diverted for irrigation and water supply, is the largest source of groundwater recharge to the study unit (Phillips and others, 2007). Primary sources of discharge are pumping withdrawals for irrigation and municipal water supply, discharge to streams, and the combination of evaporation from areas with a shallow depth to water and transpiration of water from plants (evapotranspiration).

The conceptual model of groundwater flow in the Northern San Joaquin Basin study unit (ig. 4) is based on and modified from previous investigations by Burow and others (2004) and Phillips and others (2007) in the Modesto area that focused on regional flow patterns east of the San Joaquin River. The models are similar in that within the eastern part of the Northern San Joaquin Basin study unit, regional lateral flow of groundwater is from northeast to southwest. 


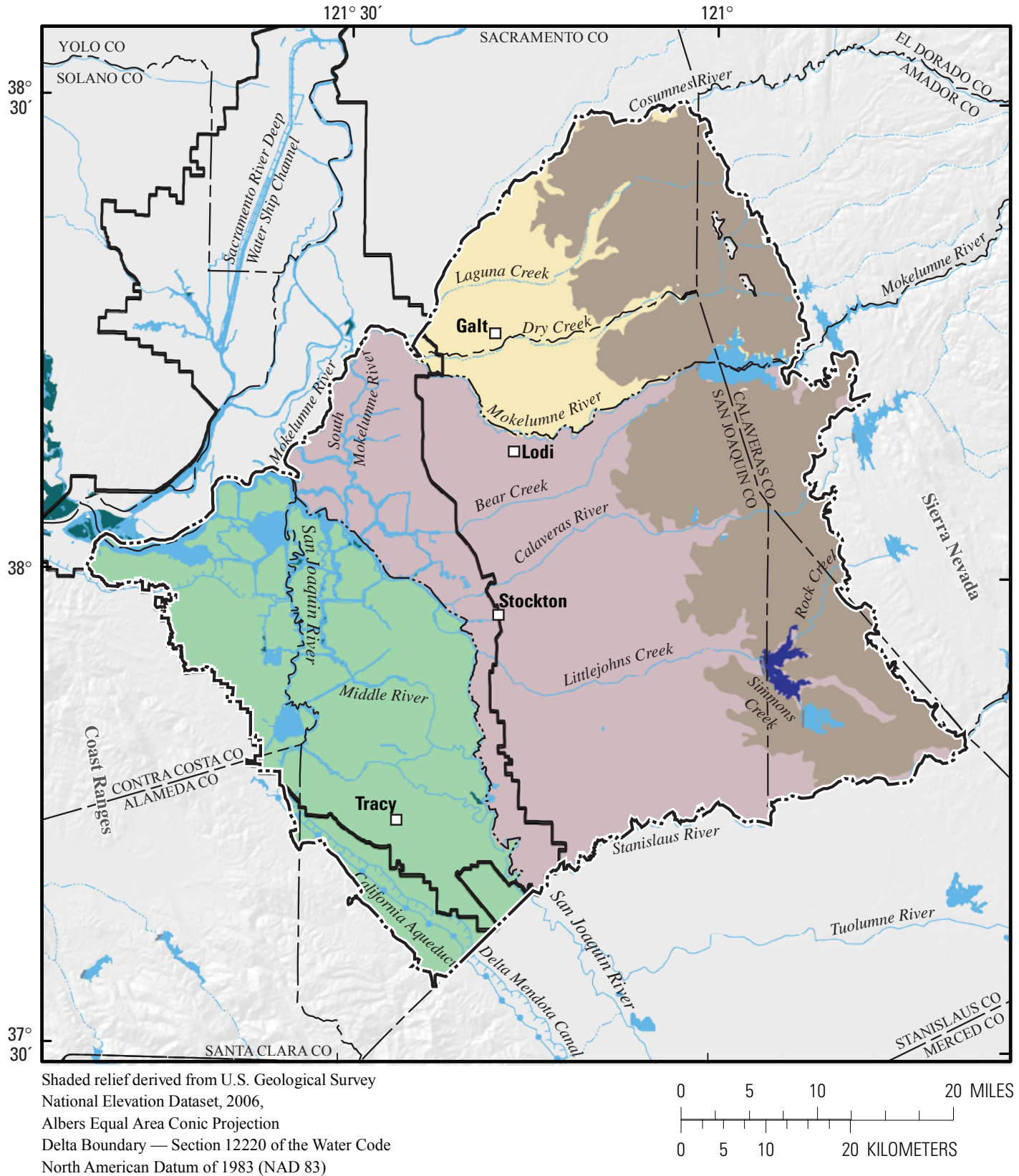

EXPLANATION

\section{Study aress}
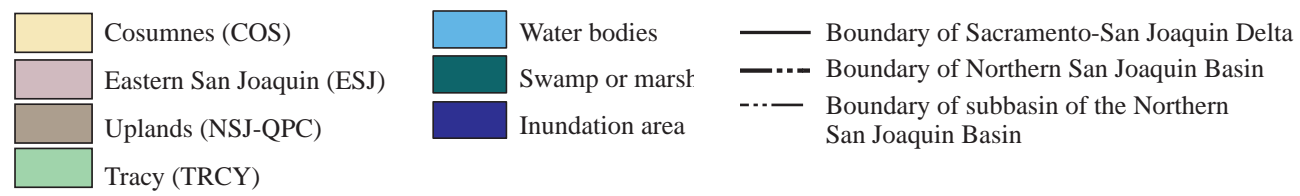

Figure 2. Geographic features and study areas of the Northern San Joaquin Basin Groundwater Ambient Monitoring and Assessment (GAMA) study unit. 


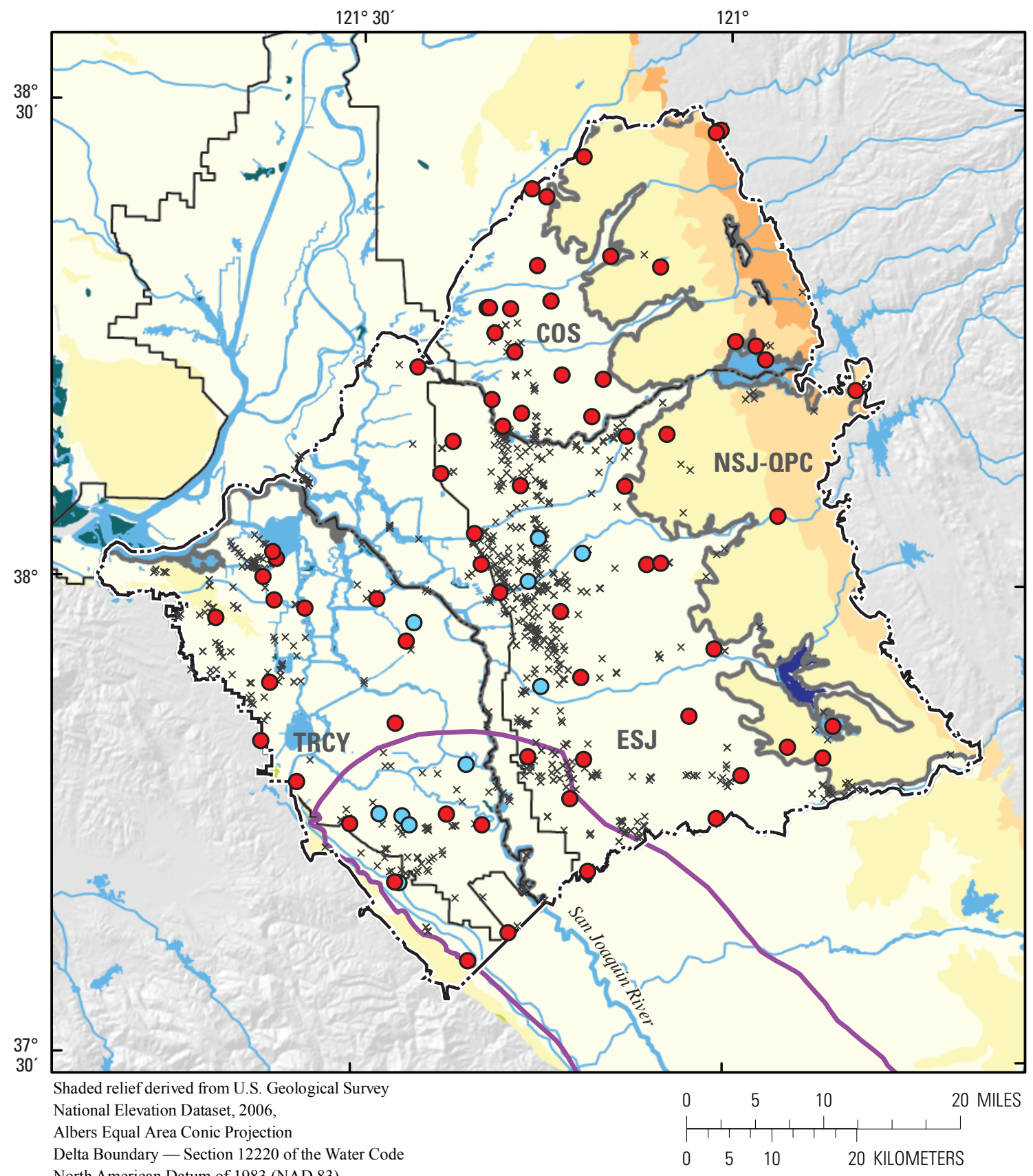

EXPLANATION

\section{Geologic units}

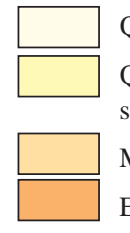

Quaternary alluvium (Q)

Quaternary/Plio-Pleistocene semi-consolidated (QPC)

$M$ iocene nonmarine consolidated (MC)

Eocene nonmarine consolidated (Ec)

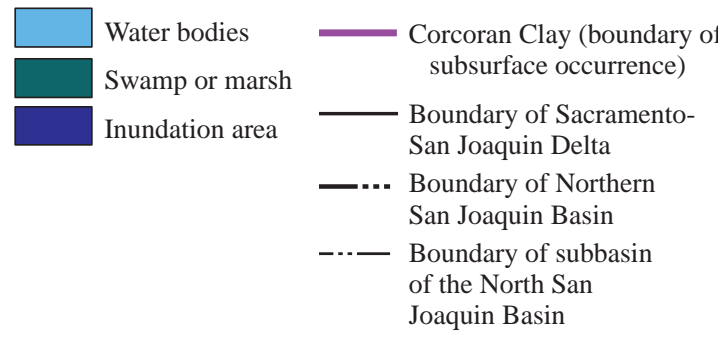

Grid wells (USGS and CDPH)

○ Understanding wells

$\times \quad$ CDPH wells only

Study aress

Cosumnes (COS)

Eastern San J oaquin (ESJ)

U plands (NSJ -QPC)

Tracy (TRCY)

Figure 3. Geologic formations, and areal distribution of grid and understanding wells, in the Northern San Joaquin Basin Groundwater Ambient Monitoring and Assessment (GAMA) study unit. 

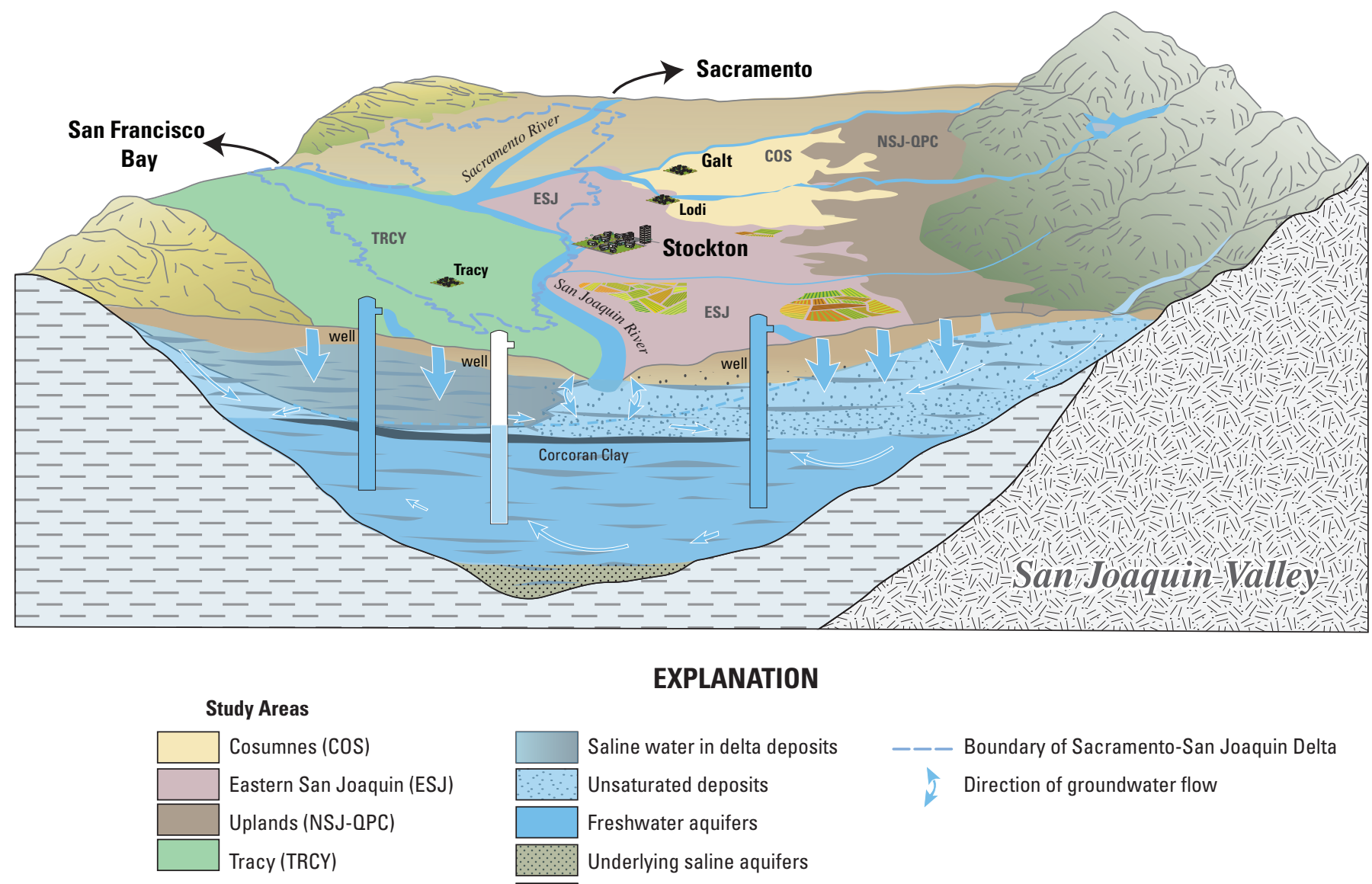

\section{EXPLANATION}
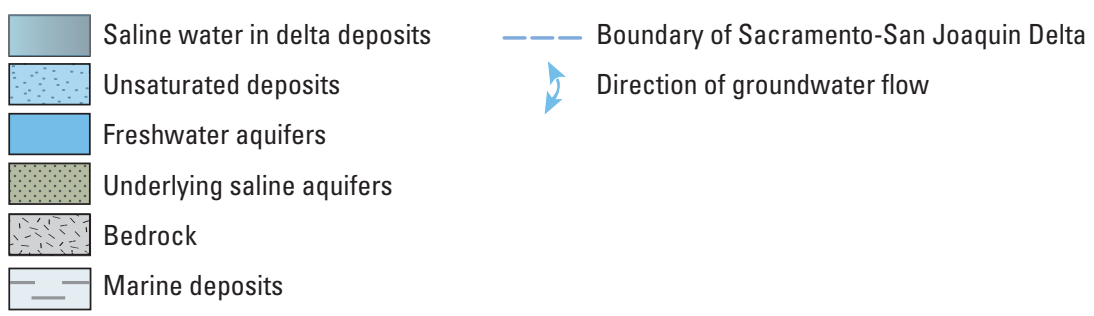

Figure 4. The aquifer system for the Northern San Joaquin Basin Groundwater Ambient Monitoring and Assessment (GAMA) study unit.

This regional flow is driven by an elevation gradient, discharge of water to the San Joaquin River, and evapotranspiration in the western part of the flow system. Within the eastern part of the Northern San Joaquin Basin study unit, return flows are a major source of recharge and withdrawals for irrigation are a major source of discharge, thereby inducing a component of downward vertical flow (Burow and others, 2007). These vertical-flow components enhance downward movement of water from recharge areas to the perforated intervals of withdrawal wells within shallow to intermediate depths in the system. These processes may occur in both agricultural and urban land-use areas. Groundwater age is vertically stratified, with water less than 50 years old in the upper parts of the system and water that may be tens of thousands of years old at depth (Burow and others, 2008). The Tracy study area, west of the San Joaquin River, contains a large part of the Sacramento-San Joaquin Delta. Historically, the Delta has served as a major discharge area for regional groundwater flow originating in the Sacramento and San Joaquin Valleys. Groundwater extractions have depressed groundwater levels along the perimeter of the Delta, thereby altering these historical flow patterns. Drawdown of groundwater levels on the Delta periphery has resulted in the interception, through the extractons, of regional discharge, including regional discharge from the nearby mountain fronts, and major streams and rivers (Izbicki and others, 2006).

Land use in the Northern San Joaquin Basin study unit is about 57 percent agricultural, 36 percent natural, and 7 percent urban, on the basis of classification of USGS National Land Cover Data (Nakagaki and others, 2007) (fig. 5). The natural land-use areas are mostly grasslands. Natural land use is dominant in the eastern parts of the study unit (fig. 5), particularly in the Upland study area. Land use in the Uplands study area is about 85 percent natural, 13 percent agricultural, and 2 percent urban. The Eastern San Joaquin study area is the most urbanized in the study unit, with about 12 percent urban land use. The city of Stockton, the largest urban area in the Northern San Joaquin Basin study unit, is in the Eastern San Joaquin study area (figs. 2 and $\underline{5}$ ). 


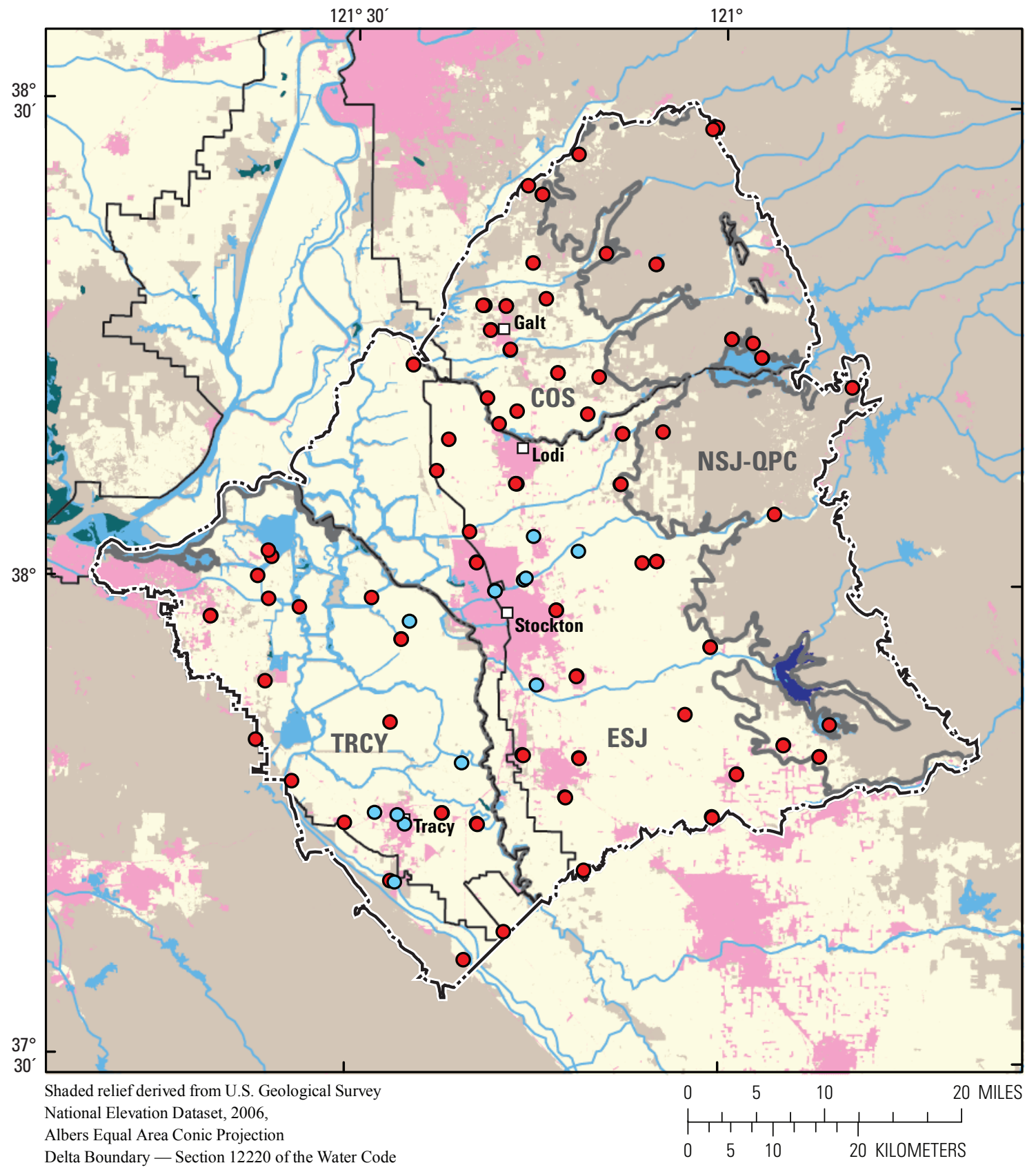

North American Datum of 1983 (NAD 83)

\section{EXPLANATION}

\section{Land use}

\begin{tabular}{|l|l|l}
\hline & U Urban & \\
\hline$\square$ & A gricultural & Water bodies \\
\hline \hline & Natural & Swamp or marsh \\
\hline & & Inundation area
\end{tabular}

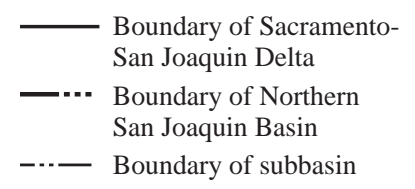

- Grid wells (USGS and CDPH)

O Understanding wells

Study areas

Cosumnes (COS)

Eastern San J oaquin (ESJ)

U plands (NSJ-QPC)

Tracy (TRCY)

Figure 5. Land use of the Northern San Joaquin Basin Groundwater Ambient Monitoring and Assessment (GAMA) study unit. 


\section{Methods}

Methods used for the USGS-GAMA Program were selected to achieve the following objectives: (1) design a sampling plan to obtain data suitable for statistical analysis; (2) combine CDPH data with data collected by the USGS-GAMA Program to assess water quality; (3) quantify the proportions of the primary aquifer with high, moderate, and low relative-concentrations for constituents of interest and constituent classes relative to water-quality benchmarks; (4) identify, on the basis of objective criteria, constituents of interest to be discussed; (5) compile and classify relevant ancillary data to identify relations of potential explanatory factors to water quality; and (6) investigate statistical relations between potential explanatory factors and water quality.

In brief, GAMA status assessments are based on equalarea grids drawn over an areal extent of the study unit. Cells within unique study areas are of equal size; however, cell sizes may differ between study areas. For example, for the Northern San Joaquin Basin study unit, four unique equal-area grids were drawn over four different study areas and although generally similar cell sizes are not exactly the same between the study areas. Two approaches, a grid-based approach and a spatially weighted approach, are used to evaluate waterquality data from drinking-water wells in the grid area. In the grid-based approach, the study unit is represented by one well per grid cell; water-quality data primarily are from one well per grid cell that was sampled by the USGS, but may be supplemented with data from the CDPH database for the same well or for nearby wells to fill gaps (either spatial or for selected constituents) in the USGS dataset. In the spatially weighted approach, data for all wells sampled by the USGS and for all wells in the CDPH database are used, and results at each well are weighted such that each grid cell contributes equally to the representation of the study unit. The two methods used to calculate aquifer-scale proportions are based on equal-area grids; thus, the proportions are areal rather than volumetric. Aquifer-scale proportions are defined as fractions (sum of all fractions equal to 1.0) of the area of the aquifer used for drinking-water supply with concentrations greater than or less than specified thresholds relative to regulatory or aesthetic benchmarks.

GAMA understanding assessments are designed to evaluate the natural and human factors that affect groundwater quality in study units. The methods used are robust enough to be applied at regional to statewide scales. The understanding assessments rely on the use of multiple lines of evidence to investigate the relations between observed water quality and potential explanatory factors.

\section{Design of Sampling Networks}

Wells selected for sampling by the USGS-GAMA Program reflect the combination of two well selection strategies. The first strategy was to randomly select wells to provide a statistically unbiased, spatially distributed assessment of the quality of groundwater resources used for drinking-water supply (USGS-grid wells) (Scott, 1990). Water-chemistry data from the randomly selected USGS-grid wells were combined with data from selected wells from the CDPH database (CDPH-grid wells) to provide complete spatial grid coverage, including data for constituents not measured at every USGS-grid well, to assess proportions of the primary aquifer with high, moderate, and low relativeconcentrations. The second strategy consisted of selecting and sampling additional wells that could be used to provide greater sample density in several areas - specifically, along regional groundwater flowpaths. A total of 10 wells were selected for this purpose (USGS-understanding wells).

The USGS-grid wells were selected using a randomized grid-based method with the intended purpose of obtained a statistically unbiased population of wells for analysis (Scott, 1990). This was accomplished by subdividing the Cosumnes, Eastern San Joaquin, Upland, and Tracy study areas into equal-area grid cells of $13,38,40$, and $35 \mathrm{mi}^{2}$, respectively, for a total of 65 grid cells (fig. 6 ). From that subdivision, wells to be sampled were randomly selected from statewide databases maintained by the CDPH and USGS (Bennett and others, 2006). If a grid cell did not contain accessible drinking water wells, then commercial, irrigation, or domestic wells were considered for sampling. One USGS-grid well was sampled in 51 of the 65 grid cells for the Northern San Joaquin Basin study unit; 10 of the 15 grid cells in the Cosumnes study area, 19 of the 20 grid cells in the Eastern San Joaquin study area, 11 of the 15 grid cells in the Tracy study area, and 11 of the 15 grid cells in the Upland study area (fig. 6). Grid cells where samples were not collected had no wells suitable for sampling, or permission to sample a suitable well in those cells could not be obtained. The wells were numbered in the order of sample collection with a prefix identifying each study area: Eastern San Joaquin, Cosumnes, Tracy, Uplands (see appendix A for a detailed description of the well-selection process and naming conventions used in this report).

The Cosumnes study area is much smaller than the other three study areas (fig. 6) highlighting the need to apply an area-weighted correction to avoid over or under representing any individual study area when reporting results at the study unit scale. The grid-based primary aquifer proportions for the study unit were determined by calculating the aquifer proportions in each study area separately, and then calculating the area-weighted sum: 


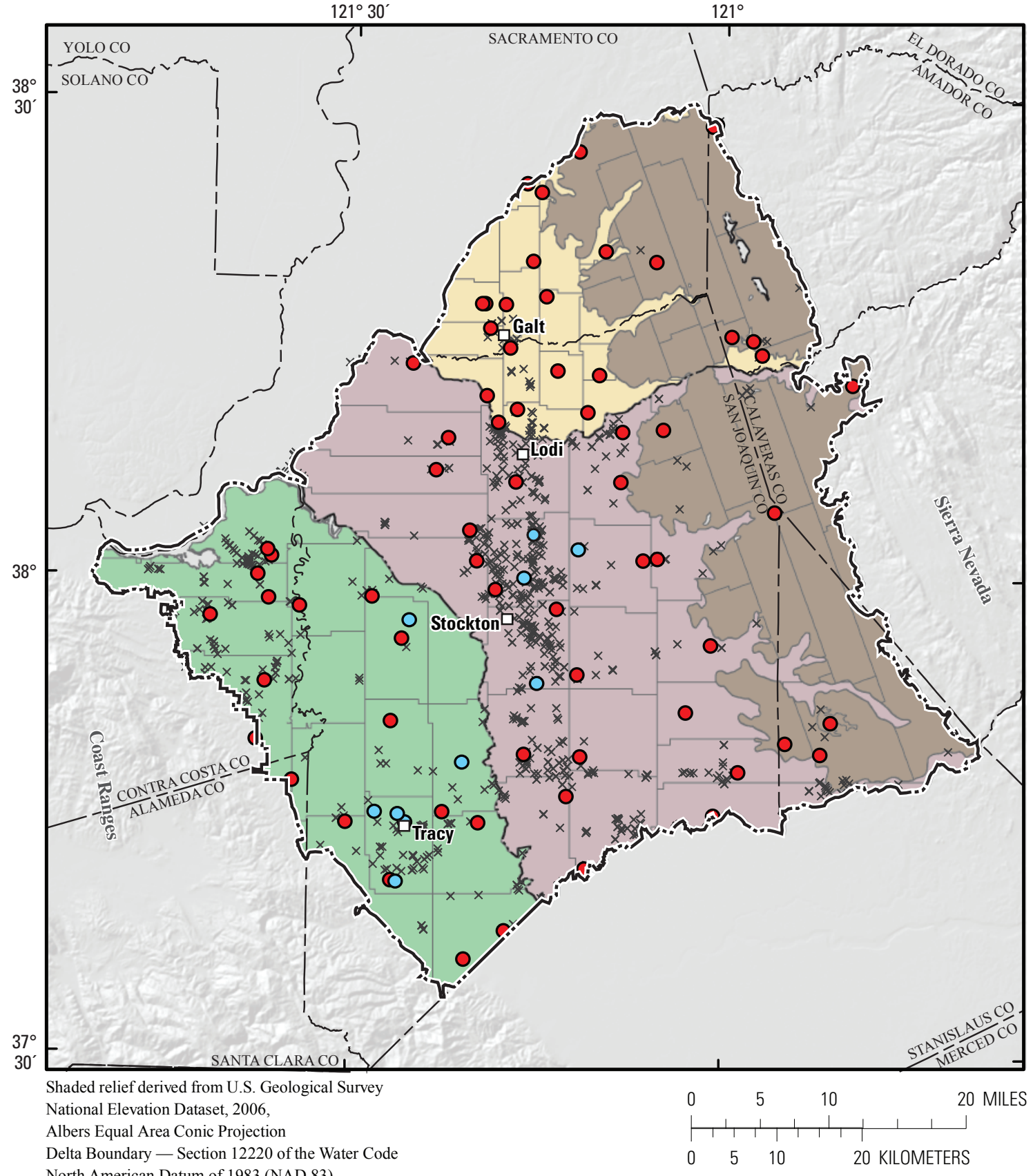

North American Datum of 1983 (NAD 83)

\section{EXPLANATION}

\section{Study areas}

\begin{tabular}{|l|l}
\hline & Cosumnes (COS) \\
\hline \hline & Eastern San J oaquin (ESJ) \\
\hline \hline & U plands (NS J -QPC) \\
\hline & Tracy (TRCY)
\end{tabular}

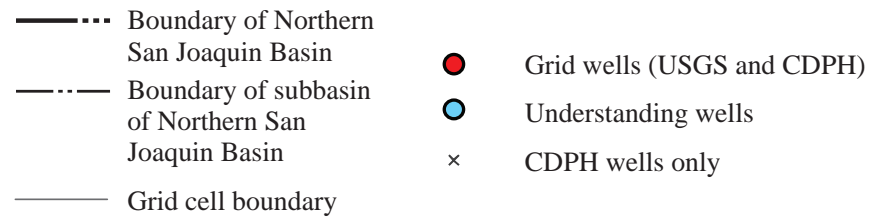

Figure 6. Study area grids, grid and understanding wells sampled, and California Department of Public Health wells used for supplemental data on inorganic constituents, Northern San Joaquin Basin Groundwater Ambient Monitoring and Assessment (GAMA) study unit. 


$$
A Q P_{S U}=\sum A Q P_{S A} F_{S A}
$$

where

$$
\begin{gathered}
A Q P_{S U} \text { is the aquifer proportion for the study unit; } \\
A Q P_{S A} \text { is the aquifer proportion for a study area; } \\
\text { and } \\
F_{S A} \text { is the fraction of the total study unit area } \\
\text { occupied by the study area. }
\end{gathered}
$$

The same weighting was applied to calculations of study-unit detection frequencies. Study-unit detection frequency is not the same as detection frequency in the grid wells. Detection frequencies for organic constituents discussed in this report might differ from those reported in Bennett and others (2006) because in the earlier report, the area-weighted correction was not applied.

Ten additional wells were sampled to provide additional data for the understanding assessment ("understanding" wells). Understanding wells were not included in the grid-based characterization of water quality in the Northern San Joaquin Basin study unit, because the inclusion of these wells could have caused overrepresentation of certain cells.

All wells (USGS-grid and understanding) were sampled using a tiered analytical approach (Bennett and others, 2006). These tiers are described briefly here. All wells in the Northern San Joaquin Basin study unit were sampled for a standard set of constituents: temperature and specific conductance, low-level VOCs, low-level 1,2-dibromo-3-chloropropane (DBCP) and 1,2-dibromomethane (EDB), pesticides and pesticide degradates, pharmaceuticals, stable isotopes of hydrogen and oxygen in water, tritium and dissolved noble gases (table 1). This set of constituents was termed the "fast" schedule because three or four wells could be sampled in 1 day, given the limited number of constituents analyzed. Wells on the "intermediate" schedule were sampled for all constituents on the fast schedule, plus gasoline oxygenates, perchlorate, $N$-nitrosodimethylamine (NDMA), low-level 1,2,3-trichloropropane (1,2,3-TCP), major and minor ions and trace elements, noble gases, and the abundance and speciation of trace elements arsenic, chromium, and iron (table 1); however, no more than two wells could be sampled in 1 day with this schedule. Wells on the "slow" schedule were sampled for all constituents on the fast and intermediate schedules, plus alkalinity, dissolved oxygen, $\mathrm{pH}$, turbidity, polar pesticides and degradates, carbon isotopes, and radioactive and microbial constituents (table 1); but only one well could be sampled per day with this schedule. The methods of collection, analysis, and quality assurance for the analytes listed in table 1 are described in Bennett and others (2006).

Assembly Bill 599, which aims to improve statewide comprehensive groundwater monitoring and increase availability of information about groundwater quality to the public, directs the GAMA Program to integrate existing monitoring data and to collect new data as necessary to achieve a comprehensive groundwater-monitoring program. The statewide CDPH database contains data for constituents with water-quality benchmarks regulated as part of Title 22 (division 2, chapter 3), a California Code of Regulation that enforces the Safe Drinking Water and Toxic Enforcement Act of 1986 (California Office of Administrative Law, 2009) Although water-quality data have been collected by other organizations for local studies and specific purposes, the CDPH database is the only California statewide database of water-chemistry data from drinking water wells available for comprehensive analysis.

Data for some constituents, specifically VOCs, pesticides, inorganic constituents, and radioactive constituents, are available from both the USGS-GAMA Program and the CDPH database (table 2), but, more VOCs and pesticides were measured as part of USGS-GAMA sampling than are available from CDPH. In addition, laboratory reporting levels (LRLs) for USGS-GAMA analyses typically were one to two orders of magnitude less than those available from CDPH. Thus, the USGS-GAMA sampling was designed to complement the CDPH data by providing a larger number of analytes and lower analytical levels at the wells sampled compared to the CDPH data available at a larger number of wells. Both datasets are used in the status and understanding assessments.

New data collected by USGS-GAMA included data for hydrologic tracers and geochemical indicators (for example, noble gases and carbon-14) that are not regulated water-quality constituents with benchmarks, but that are of importance for understanding groundwater quality. These constituents primarily are discussed in the understanding assessment. 
Table 1. Analytes and numbers of wells sampled for different analytical schedules, Northern San Joaquin Basin Groundwater Ambient Monitoring and Assessment (GAMA) study unit.

[Fast, intermediate, and slow analyte lists refer to the relative amount of time required to collect samples from a well; 1,2,3-TCP, 1,2,3-trichlorpropane; NDMA, N-nitrosodimethylamine; USGS, U.S. Geological Survey; LRL, laboratory reporting level]

\begin{tabular}{|c|c|c|c|}
\hline & \multicolumn{3}{|c|}{ Analyte Lists } \\
\hline & Fast & Intermediate & Slow \\
\hline Total number of wells & 31 & 20 & 10 \\
\hline Number of grid wells sampled & 30 & 16 & 5 \\
\hline Number of understanding wells sampled & 1 & 4 & 5 \\
\hline Analyte Groups & \multicolumn{3}{|c|}{ Number of constituents } \\
\hline Specific conductance, temperature & 2 & 2 & 2 \\
\hline Volatile organic compounds (VOCs) $^{1}$ & 85 & 85 & 85 \\
\hline Pesticides and degradates & 63 & 63 & 63 \\
\hline Noble gases and tritium ${ }^{2}$ & 7 & 7 & 7 \\
\hline Stable isotopes of hydrogen and oxygen in water & 2 & 2 & 2 \\
\hline Gasoline oxygenates ${ }^{3}$ & & 3 & 3 \\
\hline Major and minor ions, and trace elements & & 37 & 37 \\
\hline Arsenic, chromium, and iron species & & 6 & 6 \\
\hline Perchlorate, NDMA and low-level 123-TCP 4 & & 3 & 3 \\
\hline Tritium $^{5}$ & & 1 & 1 \\
\hline Alkalinity, dissolved oxygen, $\mathrm{pH}$, and turbidity & & & 4 \\
\hline Carbon isotopes & & & 2 \\
\hline Dissolved organic carbon & & & 1 \\
\hline Nutrients & & & 5 \\
\hline Polar pesticides and degradates ${ }^{6}$ & & & 58 \\
\hline Radon-222 & & & 1 \\
\hline Radium isotopes & & & 2 \\
\hline Gross alpha and beta radioactivity & & & 4 \\
\hline Microbial constituents & & & 4 \\
\hline Sum: & 159 & 209 & 290 \\
\hline
\end{tabular}

\footnotetext{
${ }^{1}$ Includes low-level 1,2,-dibromo-3-chloropropane (DBCP) and 1,2-dibromomethane (EDB), and eight other constituents classified as fumigants or fumigant synthesis by-products.

${ }^{2}$ Analyzed at Lawrence Livermore National Laboratory, Livermore, California.

${ }^{3}$ Does not include five constituents in common with VOCs.

${ }^{4}$ Includes one analyte, 123-TCP, in common with VOC analyses. However, the LRL for the low-level analysis is $0.005 \mathrm{mg} / \mathrm{L}$ compared to $0.18 \mathrm{mg} / \mathrm{L}$ for the VOC analysis. Therefore, the low-level analysis is counted as a separate analysis.

${ }^{5}$ Analyzed at USGS Stable Isotope and Tritium Laboratory, Menlo Park, California.

${ }^{6}$ Does not include four constituents in common with pesticides and degradates.
} 
Table 2. Comparison of number of compounds and median method detection levels or laboratory reporting levels by type of constituent for data stored in the California Department of Public Health (CDPH) database and data collected by the Northern San Joaquin Basin Groundwater Ambient Monitoring and Assessment (GAMA) study unit.

[MDL, method detection level; LRL, laboratory reporting level; VOC, volatile organic compound; mg/L, milligrams per liter; $\mathrm{pCi} / \mathrm{L}$, picocuries per liter; $\mu \mathrm{g} / \mathrm{L}$, micrograms per liter; nc, not collected]

\begin{tabular}{|c|c|c|c|c|c|}
\hline \multirow[b]{2}{*}{ Constituent type } & \multicolumn{2}{|c|}{ CDPH } & \multicolumn{2}{|c|}{ GAMA } & \multirow{2}{*}{$\begin{array}{l}\text { Concentration or } \\
\text { activity units }\end{array}$} \\
\hline & $\begin{array}{l}\text { Number of } \\
\text { compounds }\end{array}$ & $\begin{array}{l}\text { Median } \\
\text { MDL }\end{array}$ & $\begin{array}{l}\text { Number of } \\
\text { compounds }\end{array}$ & $\begin{array}{l}\text { Median } \\
\text { LRL }\end{array}$ & \\
\hline \multicolumn{6}{|c|}{ Inorganic constituents with health-based benchmarks } \\
\hline Trace elements & 20 & 8 & 25 & 0.12 & $\mu \mathrm{g} / \mathrm{L}$ \\
\hline Radioactive constituents & 5 & 1 & 7 & ${ }^{1} 0.54$ & $\mathrm{pCi} / \mathrm{L}$ \\
\hline Nutrients, major and minor ions & 4 & 0.4 & 17 & 0.06 & $\mathrm{mg} / \mathrm{L}$ \\
\hline \multicolumn{6}{|c|}{ Organic constituents with health-based benchmarks } \\
\hline $\begin{array}{l}\text { VOCs (including fumigants) plus gasoline } \\
\text { oxygenates }\end{array}$ & 61 & 0.5 & 88 & 0.06 & $\mu \mathrm{g} / \mathrm{L}$ \\
\hline Pesticides plus degradates & 27 & 2 & 115 & 0.019 & $\mu \mathrm{g} / \mathrm{L}$ \\
\hline \multicolumn{6}{|c|}{ Special-interest constituents with health-based benchmarks } \\
\hline$N$-Nitrosodimethylamine (NDMA) & $\mathrm{nc}$ & nc & 1 & 0.002 & $\mu \mathrm{g} / \mathrm{L}$ \\
\hline
\end{tabular}

\section{Identification of CDPH Data for Status Assessment}

The CDPH database contains historical records from more than 25,000 wells, necessitating targeted retrievals to effectively access water-quality data. For example, for the area representing the Northern San Joaquin Basin study unit, the historical CDPH database contains more than 300,000 records from more than 900 wells. CDPH data were used in two ways for the grid-based status assessment. First, the $\mathrm{CDPH}$ data were used, along with USGS-grid data, to identify constituents that have ever been measured in the Northern San Joaquin Basin study unit at concentrations greater than water-quality benchmarks, so that these constituents could be included in the status assessment. Second, for assessing aquifer proportions, the CDPH database was used as a supplemental source of inorganic constituent data for grid cells where a complete suite of inorganic constituent data was not collected by USGS-GAMA.

\section{Historically and Currently High Constituents}

Constituent concentrations were identified as historically high if (1) concentrations were high (greater than benchmarks) at any time during the full period of record of $\mathrm{CDPH}$ data in the Northern San Joaquin Basin study unit (January 10, 1984-April 21, 2004), and (2) concentrations were not high in the 3-year period (January 1, 2001-April 21, 2004) prior to the USGS-GAMA grid-well sampling (December, 2004February, 2005) in the study unit, or in USGS-grid data that resulted from this sampling (table 3 ). These constituents do not reflect current conditions on which the status assessment is based. Constituent concentrations were identified as currently high if (1) concentrations were high during the 3 -year period (January 1, 2001-April 21, 2004, hereinafter referred to as prior period) prior to the USGS-GAMA well sampling or (2) concentrations were high in the USGS-grid data (December 2004-February 2005, hereinafter referred to as the most recent). For each constituent with a high concentration (prior period and most recent), spatially weighted aquifer-scale proportions and detection frequencies in the primary aquifer were computed using the most recent concentration available within the prior period (January 1, 2001-April 21, 2004).

\section{Selection of CDPH Data for the Grid-Based Approach}

CDPH data were used in two ways: (1) the CDPH data and USGS-GAMA data were combined and used to identify constituents that had concentrations greater than water-quality 
Table 3. Constituents in California Department of Public Health (CDPH) wells at high concentrations from January 10, 1984-April 21, 2004 (the period of record prior to the 3-year period used in the status assessment), Northern San Joaquin Basin Groundwater Ambient Monitoring and Assessment (GAMA) study unit.

[A high analysis is defined as a concentration or activity that is higher than the benchmark for that constituent]

\begin{tabular}{|c|c|c|c|c|c|}
\hline Constituent & $\begin{array}{c}\text { Number of wells } \\
\text { with analyses }\end{array}$ & $\begin{array}{l}\text { Total number } \\
\text { of analyses }\end{array}$ & $\begin{array}{l}\text { Total number of } \\
\text { analyses above } \\
\text { threshold }\end{array}$ & $\begin{array}{l}\text { Number of wells } \\
\text { with at least one } \\
\text { high analysis }\end{array}$ & $\begin{array}{c}\text { Date of most } \\
\text { recent high } \\
\text { analysis }\end{array}$ \\
\hline \multicolumn{6}{|c|}{ Inorganic constituents with health-based benchmarks } \\
\hline Cadmium & 495 & 1,644 & 1 & 1 & $03 / 10 / 88$ \\
\hline Gross beta radioactivity & 104 & 446 & 2 & 2 & $12 / 03 / 91$ \\
\hline Uranium & 179 & 758 & 20 & 9 & $12 / 27 / 89$ \\
\hline \multicolumn{6}{|c|}{ Organic constituents with health-based benchmarks } \\
\hline Chloroform & 520 & 2,965 & 1 & 1 & 03/01/94 \\
\hline 1,1,2,2-Tetrachloroethane & 521 & 2,925 & 2 & 1 & $10 / 17 / 86$ \\
\hline
\end{tabular}

benchmarks in the Northern San Joaquin Basin study unit; and (2) the CDPH database was used as a supplemental source of inorganic constituent data for grid cells where inorganic constituent data were not collected by USGS-GAMA.

Procedures for selecting the wells from the CDPH database to supplement the grid are described in appendix A.

Of the 65 grid cells in the study unit, 14 cells did not have a USGS-grid well, 30 cells had a USGS-grid well but no USGS data for major ions, trace elements, nutrients, and radiochemical constituents, and 16 cells had a USGS-grid well but incomplete USGS data for radiochemical constituents. The CDPH database was queried specifically to provide these missing data (table 4). The decision tree used to identify suitable CDPH wells is described in appendix A. Selected CDPH wells used to supplement the grid data are hereafter referred to as CDPH-grid wells. All others will be referred to as USGS-grid wells.

CDPH data were not used to supplement USGS-grid well data for VOCs or pesticides for the status assessment. Data for these constituents were collected by USGS-GAMA at all 51 USGS-grid wells sampled.

\section{Status Assessment Methods}

Status assessment - an assessment of the current quality of groundwater resources - is based on computation of the relative-concentration for each constituent, where the relative-concentration is the concentration of the compound normalized to its benchmark (Toccalino and others, 2004; Toccalino and Norman, 2006). The proportions of the aquifer with high, moderate, and low relative-concentrations (defined in the subsequent section) of that compound were determined using both the grid-based and the spatially weighted approaches.

\section{Relative-Concentrations}

Relative-concentrations provide a means to relate concentrations of constituents in groundwater samples to water-quality benchmarks:

$$
\text { Relative-concentration }=\frac{\text { sample concentration }}{\text { benchmark concentration }}
$$

Toccalino and others (2004), Toccalino and Norman (2006), and Rowe and others (2007) previously used the ratio of measured concentration to a benchmark [either Maximum Contaminant Level (MCL) or Health-Based Screening Level (HBSL)] and defined this ratio as the Benchmark Quotient. Relative-concentrations used in this report are equivalent to the Benchmark Quotient of Toccalino and others (2004). However, HBSLs were not used in this report, as they are not currently used as benchmarks by California drinkingwater regulatory agencies. Relative-concentrations less than $1(<1.0)$ indicate a sample concentration less than the benchmark, and relative-concentrations greater than $1(>1.0)$ indicate a sample concentration greater than the benchmark. Relative-concentrations can be computed only for compounds with water-quality benchmarks. 
Table 4. Inorganic constituents (including the special-interest constituent perchlorate), benchmarks, and number of grid wells per constituent, Northern San Joaquin Basin Groundwater Ambient Monitoring and Assessment (GAMA) study unit.

[CDPH, California Department of Public Health; AL-US, U.S. Environmental Protection Agency (USEPA) action level; HAL-US, USEPA lifetime health advisory level; MCL-CA, CDPH Maximum Contaminant Level; MCL-US, USEPA Maximum Contaminant Level; NL-CA, CDPH Notification Level; SMCL-CA, CDPH Secondary Maximum Contaminant Level; mg/L, milligrams per liter; $\mu \mathrm{g} / \mathrm{L}$, micrograms per liter]

\begin{tabular}{|c|c|c|c|c|c|}
\hline Constituent & Benchmark type & $\begin{array}{c}\text { Benchmark } \\
\text { value }\end{array}$ & Units & $\begin{array}{l}\text { Number of } \\
\text { grid wells } \\
\text { sampled by } \\
\text { GAMA }\end{array}$ & $\begin{array}{c}\text { Number of } \\
\text { grid wells } \\
\text { selected } \\
\text { from CDPH }\end{array}$ \\
\hline \multicolumn{6}{|c|}{ Trace elements with health-based benchmarks } \\
\hline Aluminum & MCL-CA & 1,000 & $\mu \mathrm{g} / \mathrm{L}$ & 21 & 27 \\
\hline Antimony & MCL-US & 6 & $\mu \mathrm{g} / \mathrm{L}$ & 21 & 26 \\
\hline Arsenic & MCL-US & 10 & $\mu \mathrm{g} / \mathrm{L}$ & 21 & 27 \\
\hline Barium & MCL-CA & 1,000 & $\mu \mathrm{g} / \mathrm{L}$ & 29 & 20 \\
\hline Beryllium & MCL-US & 4 & $\mu \mathrm{g} / \mathrm{L}$ & 21 & 25 \\
\hline Boron & NL-CA & 1,000 & $\mu \mathrm{g} / \mathrm{L}$ & 29 & 16 \\
\hline Cadmium & MCL-US & 5 & $\mu \mathrm{g} / \mathrm{L}$ & 21 & 26 \\
\hline Chromium & MCL-CA & 50 & $\mu \mathrm{g} / \mathrm{L}$ & 21 & 26 \\
\hline Copper & AL-US & 1,300 & $\mu \mathrm{g} / \mathrm{L}$ & 21 & 26 \\
\hline Fluoride & MCL-CA & 2 & $\mathrm{mg} / \mathrm{L}$ & 21 & 22 \\
\hline Lead & AL-US & 15 & $\mu \mathrm{g} / \mathrm{L}$ & 21 & 25 \\
\hline Mercury & MCL-US & 2 & $\mu \mathrm{g} / \mathrm{L}$ & 5 & 33 \\
\hline Molybdenum & HAL-US & 40 & $\mu \mathrm{g} / \mathrm{L}$ & 21 & 0 \\
\hline Nickel & MCL-CA & 100 & $\mu \mathrm{g} / \mathrm{L}$ & 21 & 26 \\
\hline Perchlorate ${ }^{1}$ & MCL-CA & 6 & $\mu \mathrm{g} / \mathrm{L}$ & 21 & 14 \\
\hline Selenium & MCL-US & 50 & $\mu \mathrm{g} / \mathrm{L}$ & 21 & 26 \\
\hline Strontium & HAL-US & 4,000 & $\mu \mathrm{g} / \mathrm{L}$ & 21 & 0 \\
\hline Thallium & MCL-US & 2 & $\mu \mathrm{g} / \mathrm{L}$ & 21 & 26 \\
\hline Vanadium & NL-CA & 50 & $\mu \mathrm{g} / \mathrm{L}$ & 21 & 18 \\
\hline \multicolumn{6}{|c|}{ Radioactive constituents with health-based benchmarks } \\
\hline Gross alpha radioactivity & MCL-US & 15 & $\mathrm{pCi} / \mathrm{L}$ & 5 & 21 \\
\hline Gross beta radioactivity & MCL-CA & 50 & $\mathrm{pCi} / \mathrm{L}$ & 5 & 3 \\
\hline Radon-222 & MCL-US ${ }^{2}$ & 4,000 & $\mathrm{pCi} / \mathrm{L}$ & 4 & 0 \\
\hline Radium-226, -228 & MCL-US & 5 & $\mathrm{pCi} / \mathrm{L}$ & 5 & 4 \\
\hline Uranium & MCL-US & 20 & $\mathrm{pCi} / \mathrm{L}$ & 21 & 5 \\
\hline \multicolumn{6}{|c|}{ Nutrients with health-based benchmarks } \\
\hline Nitrite as nitrogen & MCL-US & 1 & $\mathrm{mg} / \mathrm{L}$ & 5 & 39 \\
\hline Nitrate plus nitrite, as nitrogen & MCL-US & 10 & $\mathrm{mg} / \mathrm{L}$ & 5 & 44 \\
\hline \multicolumn{6}{|c|}{ Major ions with SMCLs } \\
\hline Chloride & SMCL-CA & 500 & $\mathrm{mg} / \mathrm{L}$ & 29 & 18 \\
\hline Sulfate & SMCL-CA & 500 & $\mathrm{mg} / \mathrm{L}$ & 21 & 23 \\
\hline Total dissolved solids & SMCL-CA & 1,000 & $\mathrm{mg} / \mathrm{L}$ & 21 & 23 \\
\hline \multicolumn{6}{|c|}{ Trace elements with SMCLs } \\
\hline Iron & SMCL-CA & 300 & $\mu \mathrm{g} / \mathrm{L}$ & 21 & 26 \\
\hline Manganese & SMCL-CA & 50 & $\mu \mathrm{g} / \mathrm{L}$ & 21 & 26 \\
\hline Silver & SMCL-CA & 100 & $\mu \mathrm{g} / \mathrm{L}$ & 21 & 27 \\
\hline Zinc & SMCL-CA & 5,000 & $\mu \mathrm{g} / \mathrm{L}$ & 21 & 26 \\
\hline
\end{tabular}

\footnotetext{
${ }^{1}$ Special-Interest constituent.

${ }^{2}$ Proposed maximum contaminant level.
} 
In this report, relative-concentrations of constituents measured in the raw groundwater were compared with human-health benchmarks established by the U.S. Environmental Protection Agency (USEPA) and CDPH, specifically, MCLs, notification levels (NLs), health advisory levels (HALs), action levels (ALs), and risk-specific dose (1 in 100,000) (RSD5s). When both a USEPA and a California benchmark existed for a compound, the lower benchmark of the two was used. Some constituents in this report are compared to benchmarks that apply to the sum of a class of constituents, specifically, trihalomethanes (THMs). Total trihalomethane (TTHM) concentration is therefore used in statistical tests. Benchmarks established for aesthetic concerns [secondary maximum contaminant levels, (SMCL-CA; SMCL-US)] also were used for comparisons (U.S. Environmental Protection Agency, 2006; California Department of Health Services, 2007). A summary of benchmark types and concentrations for all constituents included in the status assessment is presented in table 5. Additional information on the types of benchmarks and the benchmarks for all constituents analyzed is provided by Bennett and others (2006). For ease of discussion, relative-concentrations were classified into high, moderate, and low categories.

\begin{tabular}{|l|c|c|}
\hline \multicolumn{1}{|c|}{ Category } & $\begin{array}{c}\text { Relative- } \\
\text { concentrations for } \\
\text { organic constituents }\end{array}$ & $\begin{array}{c}\text { Relative- } \\
\text { concentrations for } \\
\text { inorganic constituents }\end{array}$ \\
\hline High & $>1$ & $>1$ \\
\hline Moderate & $>0.1$ and $\leq 1$ & $>0.5$ and $\leq 1$ \\
\hline Low & $\leq 0.1$ & $\leq 0.5$ \\
\hline
\end{tabular}

Organic and special-interest constituents tend to be less prevalent and have smaller maximum relativeconcentrations than inorganic constituents. Therefore, a relative-concentration of 0.1 was used as a threshold to distinguish between low and moderate relative-concentrations of organic and special-interest constituents, compared with a relative-concentration of 0.5 used as a threshold to distinguish between low and moderate relative-concentrations for inorganic constituents. As an example, the USEPA has previously used a relative-concentration of 0.1 as a threshold equal to or greater than which the USEPA wants to be informed of the presence of a pesticide in surface water or groundwater (U.S. Environmental Protection Agency, 1998).

\section{Estimation of Aquifer-Scale Proportions}

Two statistical approaches, grid-based and spatially weighted, were selected to evaluate the proportions of the primary aquifer in the Northern San Joaquin Basin study unit with high, moderate, or low relative-concentrations of constituents relative to benchmarks. Detection frequencies also were calculated for individual constituents without any areal or spatial correction for comparison (hereafter referred to as a raw detection frequency), but were not used for estimating aquifer-scale proportions because this method creates spatial bias towards areas with large numbers of wells.

1. Grid-based: One value per grid cell was used to represent the primary aquifer. Data were from the USGS-grid and CDPH-grid wells discussed in section, "Selection of CDPH Data for the Grid-Based Approach." The proportion of the primary aquifer with high relative-concentrations was computed by dividing the number of cells represented by a high concentration for that constituent by the total number of grid cells with data for that constituent. Proportions of moderate and low relative-concentrations were calculated similarly. Due to disproportionate study area size, proportions are areally corrected using the approach described in section, "Design of Sampling Networks." For constituent classes, grid cells were assigned a high or moderate classification based on individual members in the constituent class with high or moderate relative-concentrations. Confidence intervals for grid-based aquifer proportions were computed using the Jeffreys interval for the binomial distribution (Brown and others, 2001). Although the grid-based estimate is spatially unbiased, it may not detect constituents that are present at high relative-concentrations in small proportions of the primary aquifer.

2. Spatially weighted: All CDPH wells in the study unit (most recent analysis from each well with data for a constituent during the prior period (January 1, 2001-April 21, 2004), USGS-grid wells, and USGS-understanding wells were used to represent the primary aquifer. Using the spatially weighted approach, the proportion of high relative-concentrations for the primary aquifer for each constituent was computed by (a) computing the proportion of wells with high relative-concentrations in each grid-cell; and (b) averaging together the grid-cell proportions computed in step (a) (Isaaks and Srivastava, 1989). Similar procedures were used to calculate the proportions of the aquifer with moderate and low relative-concentrations of constituents. The resulting proportions are spatially unbiased (Isaaks and Srivastava, 1989).

The raw detection frequencies of wells with high relativeconcentrations for constituents were calculated using the same data that were used for the spatially weighted approach. However, raw detection frequencies are not spatially unbiased because the wells in the CDPH database are not uniformly distributed. Consequently, high relative-concentrations in an area representing a small part of the primary aquifer might give that area a disproportionately high weight compared to spatially unbiased methods. Raw detection frequencies of high relative-concentrations are provided for reference in this report but were not used to determine aquifer-scale proportions. 
Table 5. Benchmark type and value for constituents included in the assessment of status of groundwater quality in the Northern San Joaquin Basin Groundwater Ambient Monitoring and Assessment (GAMA) study unit.

[Benchmark type: MCL-US, U.S. Environmental Protection Agency (USEPA) maximum contaminant level; MCL-CA, California Department of Public Health $(\mathrm{CDPH})$ maximum contaminant level; HAL-US, USEPA lifetime health advisory level; NL-CA, CDPH notification level. Benchmark units: mg/L, milligrams per liter; $\mu \mathrm{g} / \mathrm{L}$, micrograms per liter; $\mu \mathrm{S} / \mathrm{cm}$, microsiemens per centimeter; $\mathrm{pCi} / \mathrm{L}$, picocuries per liter]

\begin{tabular}{|c|c|c|c|c|}
\hline \multirow[b]{2}{*}{ Constituent } & \multirow[b]{2}{*}{ Typical use or source } & \multicolumn{3}{|c|}{ Benchmarks } \\
\hline & & Type & $\begin{array}{c}\text { Concentration/ } \\
\text { activity }\end{array}$ & Units \\
\hline \multicolumn{5}{|c|}{ Trace elements with health-based benchmarks } \\
\hline Aluminum $^{1}$ & naturally occurring & MCL-CA & 1,000 & $\mu \mathrm{g} / \mathrm{L}$ \\
\hline Barium & naturally occurring & MCL-CA & 1,000 & $\mu \mathrm{g} / \mathrm{L}$ \\
\hline Boron & naturally occurring & NL-CA & 1,000 & $\mu \mathrm{g} / \mathrm{L}$ \\
\hline Fluoride $^{1}$ & naturally occurring & MCL-CA & 2,000 & $\mu \mathrm{g} / \mathrm{L}$ \\
\hline Lead $^{1}$ & naturally occurring & MCL-US & 15 & $\mu \mathrm{g} / \mathrm{L}$ \\
\hline Mercury ${ }^{1}$ & naturally occurring & MCL-US & 2 & $\mu \mathrm{g} / \mathrm{L}$ \\
\hline Uranium $^{1}$ & naturally occurring & MCL-CA & 20 & $\mathrm{pCi} / \mathrm{L}$ \\
\hline \multicolumn{5}{|l|}{ Nutrients } \\
\hline Nitrate plus nitrite, as nitrogen & natural, fertilizer, sewage & MCL-US & 10 & $\mathrm{mg} / \mathrm{L}$ \\
\hline Nitrite, as nitrogen & natural, fertilizer, sewage & MCL-US & 1 & $\mathrm{mg} / \mathrm{L}$ \\
\hline \multicolumn{5}{|c|}{ Major and minor ions, and trace elements with SMCLs } \\
\hline Chloride & naturally occurring & SMCL-CA & 500 & $\mathrm{mg} / \mathrm{L}$ \\
\hline Iron & naturally occurring & SMCL-CA & 300 & $\mu \mathrm{g} / \mathrm{L}$ \\
\hline Manganese & naturally occurring & SMCL-CA & 50 & $\mu \mathrm{g} / \mathrm{L}$ \\
\hline Specific conductance & naturally occurring & SMCL-CA & 1,600 & $\mu \mathrm{S} / \mathrm{cm}$ \\
\hline Sulfate & naturally occurring & SMCL-CA & 500 & $\mathrm{mg} / \mathrm{L}$ \\
\hline
\end{tabular}

Organic and special-interest constituents

Volatile organic compounds (VOCs)

Chloroform

1,1-Dichloroethene ${ }^{1}$

1,2-Dichloroethane ${ }^{2}$

cis-1,2-Dichloroethene $^{1}$

Methyl-tert-butyl-ether (MTBE)

Tetrachloroethene (PCE)

Trichloroethene (TCE) ${ }^{1}$

Vinyl chloride ${ }^{2}$

disinfection by-product
solvent
solvent, fumigant, plastics
solvent
gasoline oxygenate
dry-cleaning, metal degreasing
dry-cleaning, metal degreasing
organic systhesis

\section{Fumigants}

1,2-Dibromo-3-chloropropane (DBCP)

1,2-Dibromoethane (EDB) ${ }^{1}$

1,2-Dichloropropane (1,2-DCP) ${ }^{1}$

1,4-Dichlorobenzene ${ }^{2}$

\section{Pesticides}

Simazine

\section{Special-interest constituents}

Perchlorate

MCL-US
MCL-CA
MCL-CA
MCL-CA
MCL-CA
MCL-US
MCL-US
MCL-CA

$\begin{array}{cc}80 & \mu \mathrm{g} / \mathrm{L} \\ 6 & \mu \mathrm{g} / \mathrm{L} \\ 0.5 & \mu \mathrm{g} / \mathrm{L} \\ 6 & \mu \mathrm{g} / \mathrm{L} \\ 13 & \mu \mathrm{g} / \mathrm{L} \\ 5 & \mu \mathrm{g} / \mathrm{L} \\ 5 & \mu \mathrm{g} / \mathrm{L} \\ 0.5 & \mu \mathrm{g} / \mathrm{L}\end{array}$

$\begin{array}{cc}\text { fumigant } & \text { MCL-US } \\ \text { fumigant } & \text { MCL-US } \\ \text { industrial, fumigant } & \text { MCL-US } \\ \text { fumigant } & \text { MCL-CA }\end{array}$

$\begin{array}{ll}0.2 & \mu \mathrm{g} / \mathrm{L} \\ 0.05 & \mu \mathrm{g} / \mathrm{L} \\ 5 & \mu \mathrm{g} / \mathrm{L} \\ 5 & \mu \mathrm{g} / \mathrm{L}\end{array}$

\footnotetext{
${ }^{1}$ Included on the basis of concentrations reported in CDPH database. Constituent also detected by USGS-GAMA at low relative-concentrations.

${ }^{2}$ Included on the basis of concentrations reported in CDPH database. Constituent not detected by USGS-GAMA
} 
The grid-based and spatially weighted estimates of aquifer-scale proportions, based on a spatially distributed grid-cell network across the study unit, are intended to characterize the water quality of the aquifer at depths that typically are used for drinking-water supply. These approaches assign weights to wells based on a single well per cell (grid-based) or the number of wells per cells (spatially weighted). Another possible approach would have been to assign weights to wells on the basis of water use (withdrawal rate). However, water-use data for drinking water and other wells generally are not available. Moreover, this approach, even if withdrawal data were available for all wells, would characterize the volume of groundwater currently used for drinking-water supply, which would likely be weighted towards fewer wells and smaller areas than the approaches used, which were based on spatially distributed grid cells across the study unit.

\section{Understanding Assessment Methods}

The understanding assessment - where natural and anthropogenic factors are related to changes in groundwater quality - is dependent on statistical testing of both the water-quality constituents and a set of explanatory factors. Constituents of interest were analyzed in relation to explanatory factors, specifically, land use, well depth, depth to top-of-perforation, normalized lateral position, groundwater age, and geochemical conditions, in order to establish context for physical and chemical processes. Statistical tests were used to identify significant correlations between the constituents of interest and the potential explanatory factors. The strongest correlations for factors influencing water quality are shown graphically.

A subset of the constituents examined in the status assessment, plus selected classes of constituents, were examined in the understanding assessment:

- Constituents with high relative-concentrations in greater than 2 percent of the aquifer. These constituents were selected to focus the understanding assessment on those constituents that have the widest effect on raw water quality in the primary aquifer.

- Classes of constituents that had no individual constituents with high relative-concentrations in greater than 2 percent of the aquifer, but had individual constituents with high relative-concentrations in a small proportion of the aquifer (less than 2 percent) or moderate relative-concentrations in greater than 2 percent of the aquifer.

- Classes of organic constituents that included one or more constituents detected in more than 10 percent of USGS-grid wells, regardless of concentration.
Grid wells (USGS and CDPH) and understanding wells were used for the understanding assessment. Correlations between water-quality variables and potential explanatory factors were tested using either the set of grid and understanding wells combined or grid wells only. Understanding wells were included in analyses of relations between constituents and the vertically distributed explanatory factors well depth, depth to top-of-perforation, groundwater age, and geochemical conditions, to aid in the identification of relationships. However, because the understanding wells were not randomly selected on a spatially distributed grid, they were excluded from analyses of relations of water quality to areally distributed variables (land use and normalized lateral position) to avoid areal-clustering bias. Classes of organic constituents, specifically, TTHMs, solvents, fumigants, and pesticides were compared to explanatory factors as sums of raw concentrations, meaning, if multiple constituent concentrations within a class were detected in the same well they were added together prior to analysis.

\section{Statistical Analysis}

Nonparametric statistical methods were used to test the significance of correlations between water-quality variables and potential explanatory factors. Nonparametric statistics are robust techniques that generally are not affected by outliers and do not require that the data follow any particular distribution (Helsel and Hirsch, 2002). The significance level (p) used for hypothesis testing for this report was compared to a threshold value $(\alpha)$ of 5 percent $(\alpha=0.05)$ to evaluate whether the relation was statistically significant $(p<\alpha)$. Correlations were investigated using Spearman's method to calculate the rank-order correlation coefficient, rho, between continuous variables. The values of rho can range from +1.0 (perfect positive correlation), through 0.0 (no correlation), to -1.0 (perfect negative correlation). For potential explanatory factors that were classified into categories (for example, groundwater-age categories of young and old), the values of water-quality parameters between the categories were compared using the Wilcoxon rank-sum test. Raw concentrations for classes of compounds, for example solvents, were summed prior to grouping and testing. The Wilcoxon rank-sum test is a median test statistic that compares two independent data groups (categories) to determine whether one group contains larger values than the other (Helsel and Hirsch, 2002). The null hypothesis for the Wilcoxon rank-sum test is that there is no significant difference between the observations of the two independent data groups being tested, therefore significant differences between groups are noted by small p-values $(<0.05)$. All statistical analyses were done using TIBCO Spotfire $\mathrm{S}+\circledR 8.1$ for Windows. 


\section{Potential Explanatory Factors}

The potential explanatory factors land use, well depth, depth to top-of-perforation, normalized lateral position, groundwater age, and geochemical conditions are described briefly in this section. Correlations between explanatory factors that might affect apparent relations between explanatory factors and water quality also are described. The data sources and methodology used for assigning values for potential explanatory factors are described in appendix B: Ancillary Data Sets.

\section{Land Use}

Land use in this study is reported as the relative percentage of three major land-use categories (agricultural, urban, and natural) calculated at the scale of the study unit, individual study areas, and within 500-m buffers surrounding grid wells (USGS-grid wells supplemented with additional CDPH grid wells) and all wells in the CDPH database (appendix B). Land use based on the study unit as a whole (all land within the study unit boundaries) primarily is agricultural ((57 percent; see in-text table). Land use with respect to priority constituents was evaluated as percentages of land use within 500-m buffers surrounding sampled wells. The 500-m buffer represents a contributing area as defined and evaluated by Johnson and Belitz (2009). Land use within 500-m buffers of all grid wells also primarily was agricultural (53 percent agricultural, 24 percent urban, and 23 percent natural). The more urbanized average land use for the buffer areas surrounding grid wells ( 24 percent) compared to the study unit as a whole (7 percent) shows that drinking water wells commonly are located in or near communities, which may result in a bias toward urbanized areas in the results. Urban land-use percentages for the 500-m buffer areas surrounding grid and CDPH wells are as much as four times greater than urban land-use percentages in the study unit as a whole (see in text table). The natural-land-use category is most prevalent in the Upland study area where, relative to the other study areas, few grid wells were sampled (fig. 5). The differences between average land use surrounding the grid and CDPH wells reflect differences in the spatial distributions of each dataset, with grid wells being more evenly distributed due to the grid approach and CDPH wells being more clustered in urban environments closer to population centers.

When examining the predominant land use (greater than 50 percent) with respect to the buffered area surrounding grid wells, the Cosumnes, Eastern San Joaquin, and Tracy study areas primarily are agricultural; however, natural land use is dominant in the Uplands study area. When examining the buffered area surrounding CDPH wells, the pattern of dominant land use changes from agricultural to mixed (no land use greater than 50 percent) in the Cosumnes and Eastern San Joaquin study areas, but remains agricultural and natural in Tracy and Uplands study areas, respectively (fig. 7A).

Understanding wells were nearly equally distributed between predominantly agricultural and predominantly urban areas (fig. $7 B$ ). One of the understanding wells was located in an area with greater than 50 percent natural land use. Four understanding wells were located in areas with greater than 70 percent urban land use within the 500 -m buffers, and the remaining wells were located in areas with less than 45 percent urban land use within the 500-m buffer.

An additional subcategory of agricultural land use, orchard/vineyard, was included in the statistical analysis of fumigant concentrations. Orchard and vineyard land use, which occurs in all study areas, previously was found to be related to concentrations of nitrate and some pesticides in parts of the eastern San Joaquin Valley (Domagalski, 1997; Burow and others, 1998a). For grid wells, the percentage of orchard/ vineyard land use ranged from 0 to 100 , with a median of 31 . For the understanding wells, the percentage of orchard/ vineyard land use ranged from 0 to 84 , with a median of 48 .

\begin{tabular}{|l|c|c|c|l|}
\hline \multicolumn{7}{|c|}{ Land-use category } \\
\hline & $\begin{array}{c}\text { Agricultural } \\
\text { (percent) }\end{array}$ & $\begin{array}{c}\text { Urban } \\
\text { (percent) }\end{array}$ & $\begin{array}{c}\text { Natural } \\
\text { (percent) }\end{array}$ & Classification \\
\hline Study unit as a whole & 57 & 7 & 36 & Agricultural \\
\hline $\begin{array}{c}\text { Study unit based on buffer areas } \\
\text { surrounding grid wells }\end{array}$ & 53 & 24 & 23 & Agricultural \\
\hline $\begin{array}{c}\text { Study unit based on buffer areas } \\
\text { surrounding CDPH wells }\end{array}$ & 41 & 29 & 29 & Mixed \\
\hline
\end{tabular}




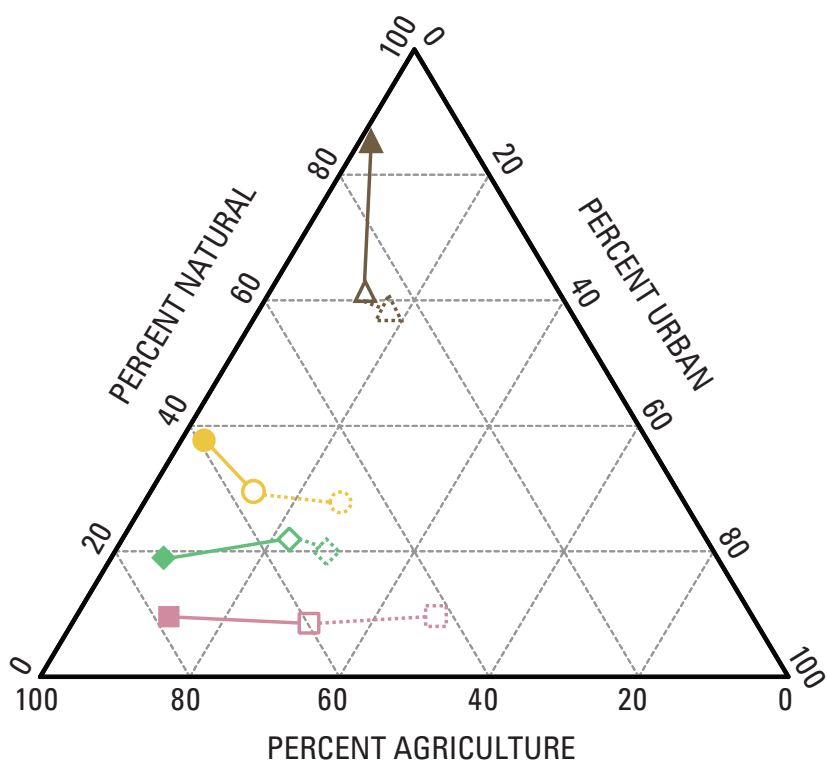

A. Individual study areas and study areas based on a 500-m buffer surrounding grid and CDPH wells

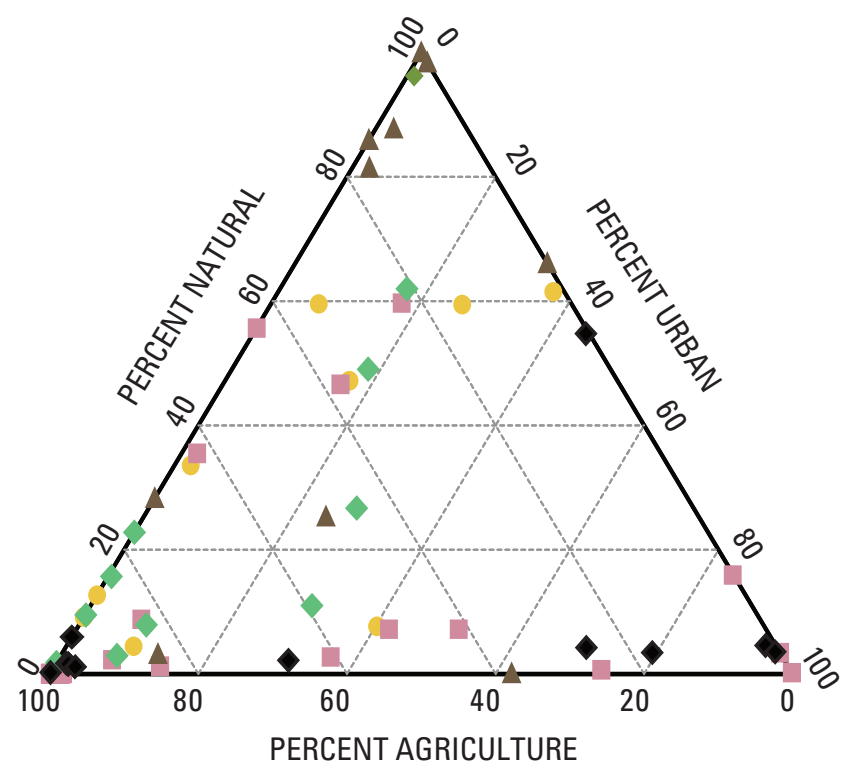

B. Grid and understanding wells in each study area based on land use within a 500-meter buffer surrounding the wells.

\section{EXPLANATION}

\section{Study area land use (Cosumnes used as example)}

Individual study areas (filled symbols)

Based on 500-meter buffer surrounding grid wells (open symbols)

Based on 500-meter buffer surrounding CDPH wells in study area (dashed open symbols)

\section{Wells}

- Cosumnes grid

- Eastern San Joaquin grid

- Uplands grid

$\checkmark$ Tracy grid

- Understanding

Figure 7. Proportions of urban, agricultural, and natural land use, Northern San Joaquin Groundwater Ambient Monitoring and Assessment (GAMA) study unit. 


\section{Well Depth and Depth to Top-of-Perforation}

Grid wells primarily are used for drinking-water supply. Well depths ranged from 83 to $930 \mathrm{ft}$ below land surface (BLS), with a median of $360 \mathrm{ft}$ BLS (fig. 8). Depths to the top-of-perforation ranged from 23 to $750 \mathrm{ft}$ BLS, with a median of $180 \mathrm{ft}$ BLS. The perforation length was as much as $470 \mathrm{ft}$, with a median of $177 \mathrm{ft}$. These values represent different sets of wells because more well depths were known than depths to top-of-perforation.

The understanding wells generally were deeper (although not statistically significantly deeper) and screens were longer than the depths and screens in the grid wells (fig. 8). The median well depth, median depth to top-of-perforation, and median perforation length for understanding wells were 460 , 200 , and $268 \mathrm{ft}$, respectively.

\section{Normalized Lateral Position}

The normalized lateral position of wells (figs. $9 A$ and $\underline{9 B}$ ) serves as a proxy for the horizontal position in the regional groundwater-flow system and is calculated as the ratio of the distance from the well to the upgradient edge of the regional groundwater-flow system (valley margin) to the total distance from the center of the valley (valley trough) to the valley margin (appendix B). The valley margins (eastern and western edges of the San Joaquin Valley) in this description represent the upgradient ends of the regional-flow system and high values of normalized lateral position. The valley trough (basin center) represents the downgradient end of the regional-flow system and low values of normalized lateral position. Grid wells were distributed across the entire range of normalized lateral positions (fig. $9 \mathrm{~A}$ ). Wells with a range of normalized lateral positions of $0.20-0.39,0.40-0.59$, and $0.60-0.79$, made up 20,27, and 14 percent of the grid wells, respectively (fig. 9A). Wells with a normalized lateral position of 0.0 to less than 0.20 (near valley trough) and greater than 0.80 (near valley margin) made up 22 and 17 percent of the grid wells, respectively (fig. 9B).

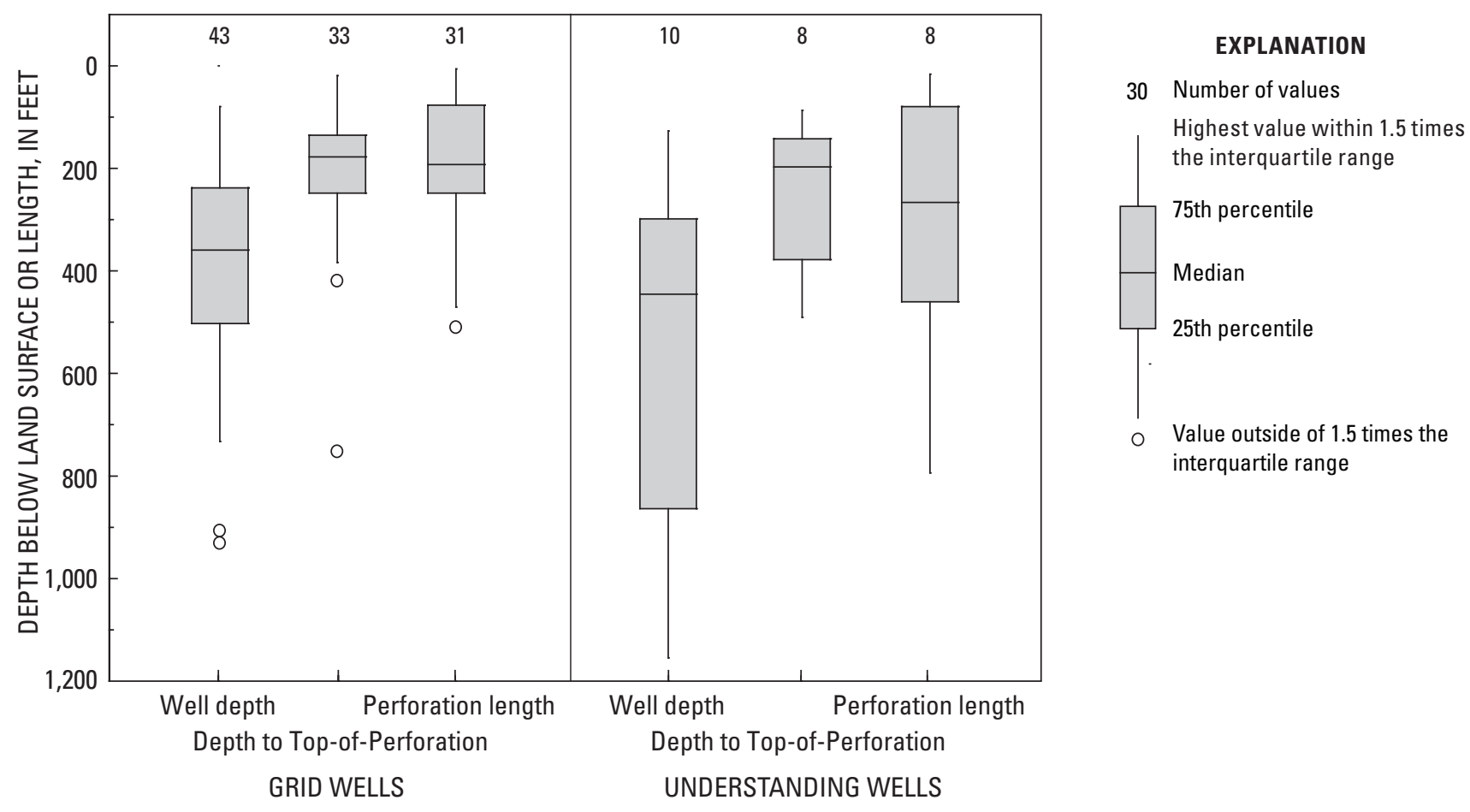

Figure 8. Well depths, depths to top-of-perforation, and perforation lengths for grid and understanding wells, Northern San Joaquin Basin Groundwater Ambient Monitoring and Assessment (GAMA) study unit. 


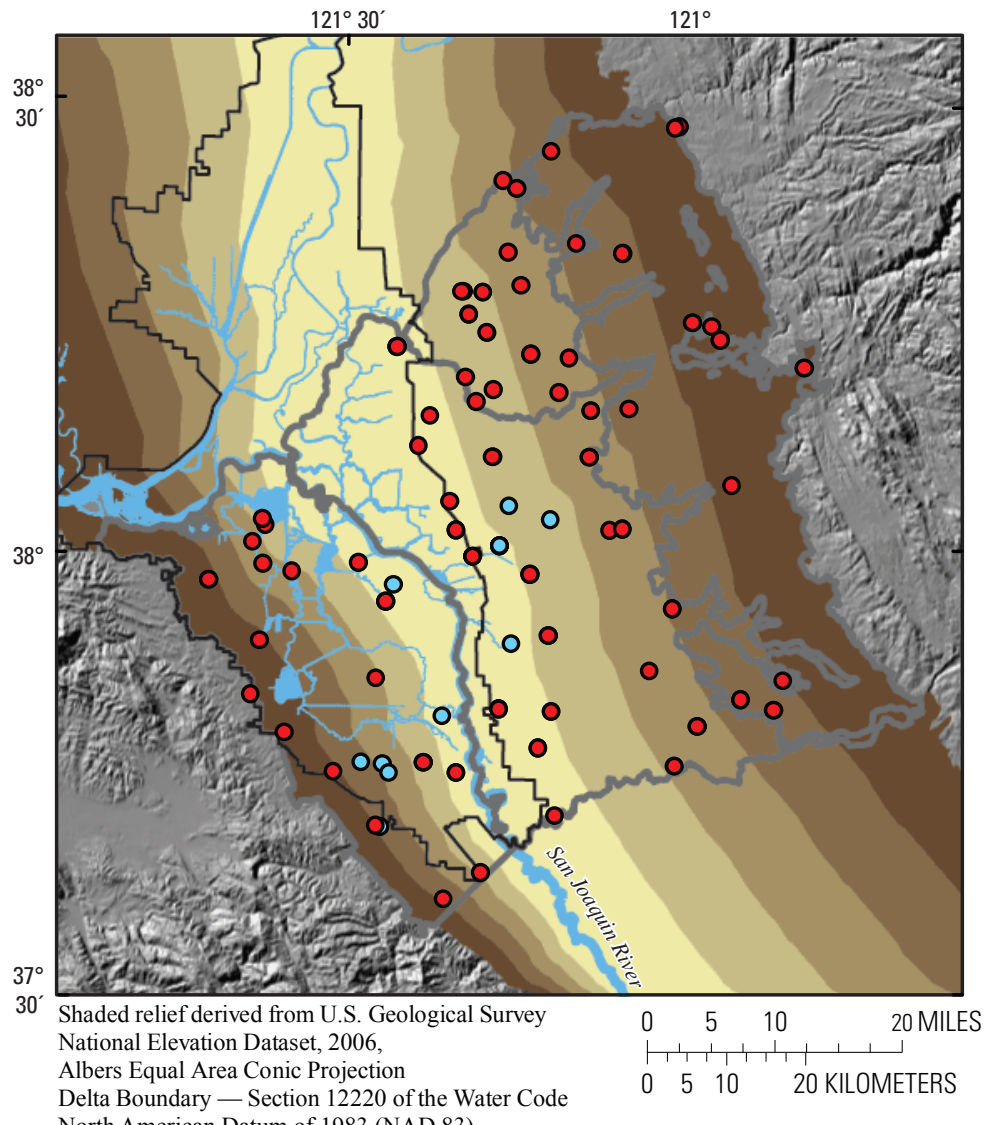

A. Distribution of wells plotted on visualization of normalized lateral positions.

\section{EXPLANATION}
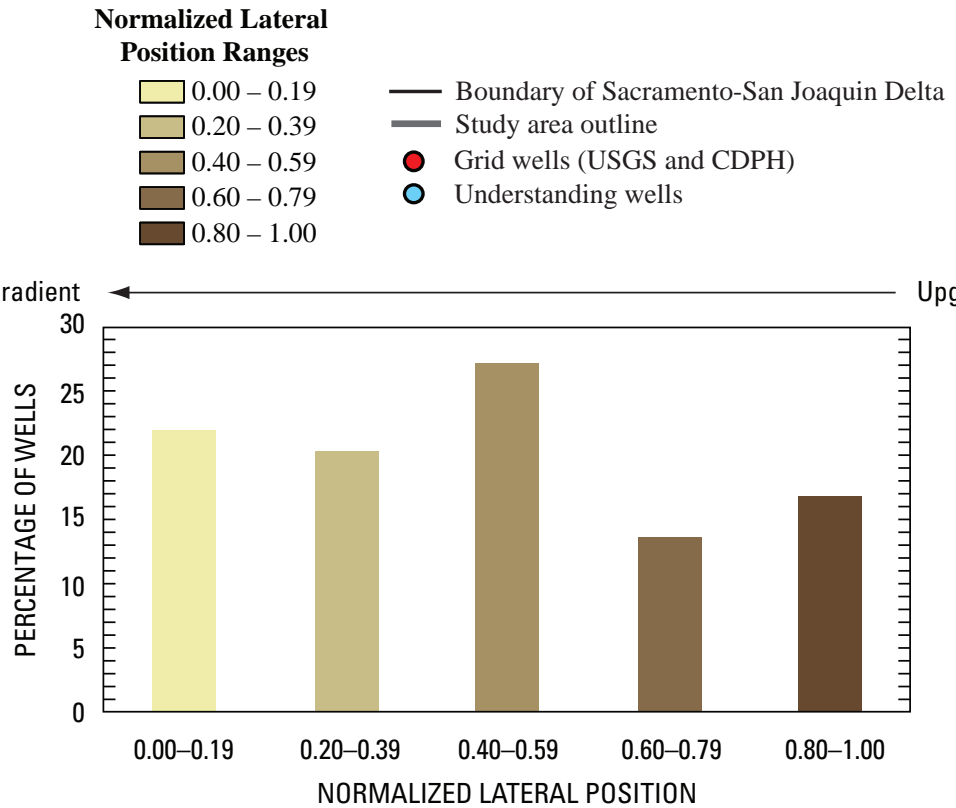

Upgradient

B. Grid and understanding wells in each study area based on land use within a 500 -meter buffer surrounding the wells.

Figure 9. Distribution of wells plotted on visualization of normalized lateral positions and across the range of normalized lateral positions, Northern San Joaquin Basin Groundwater Ambient Monitoring and Assessment (GAMA) study unit. 


\section{Groundwater Age}

Groundwater age of the 61 groundwater samples obtained by USGS-GAMA in the Northern San Joaquin Basin study unit were classified by using tritium concentrations. Tritium was the only age tracer collected at all wells; the combination of tritium, carbon-14 $\left({ }^{14} \mathrm{C}\right)$, and noble-gas data were available for a subset of wells. Tritium concentrations alone can not be used to accurately define groundwater age; however, the relative abundance of tritium is a useful indicator of the

$\boldsymbol{A}$

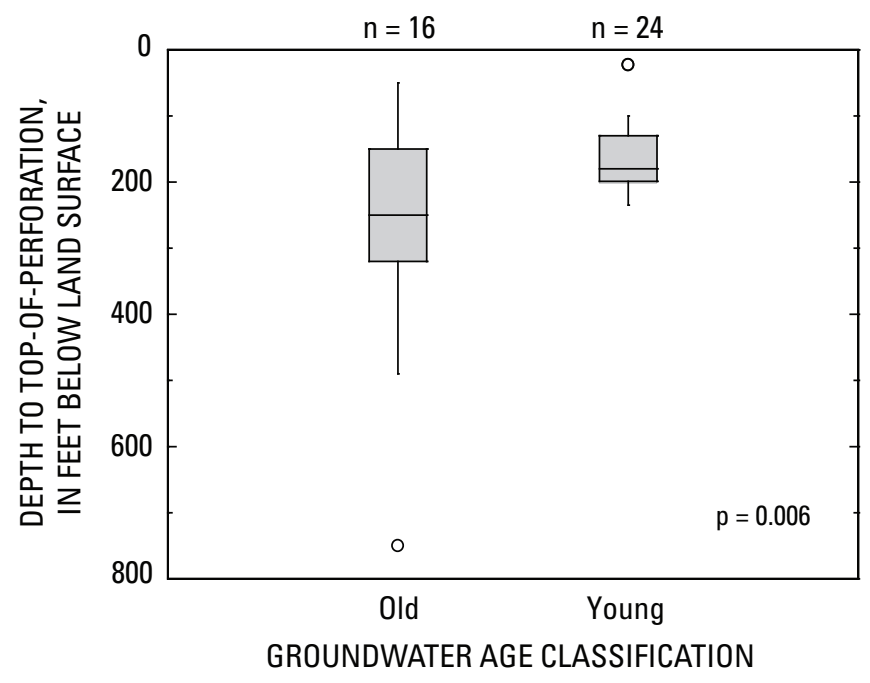

B

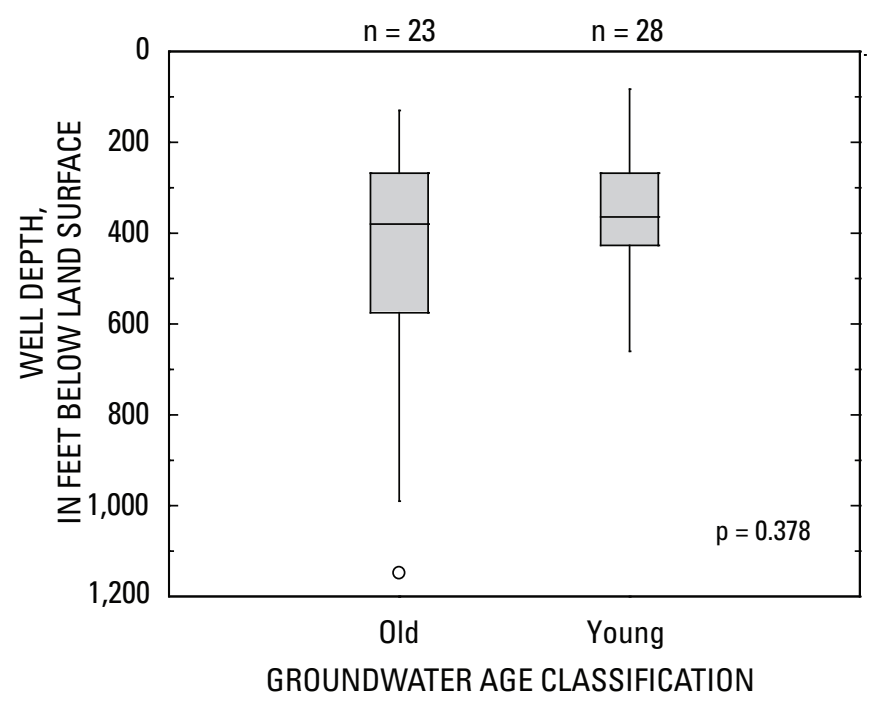

presence of young water. Wells with tritium concentrations less than $1 \mathrm{pCi} / \mathrm{L}$ were classified as old (recharged prior to 1950) and those with tritium concentrations equal to or greater than $1 \mathrm{pCi} / \mathrm{L}$ were classified as young (recharged after 1950) (Michel, 1989; Michel and Schroeder, 1994; Solomon and Cook, 2000) (appendix B).

Groundwater classified as old occurred significantly more often in wells with deeper depths to top-of-perforation (fig. 10A, table 6); however, groundwater age was not correlated with well depth alone (fig. 10B, table 6).

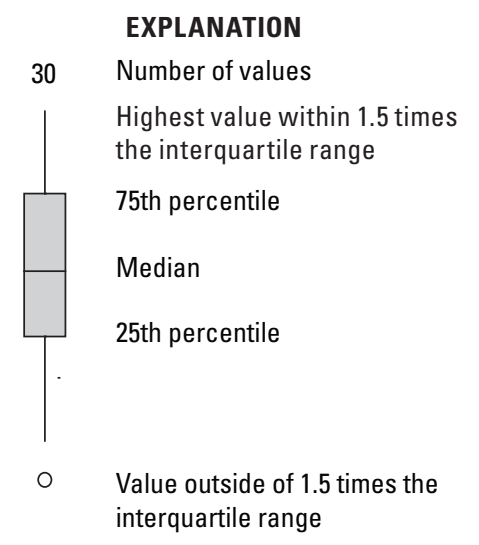

C

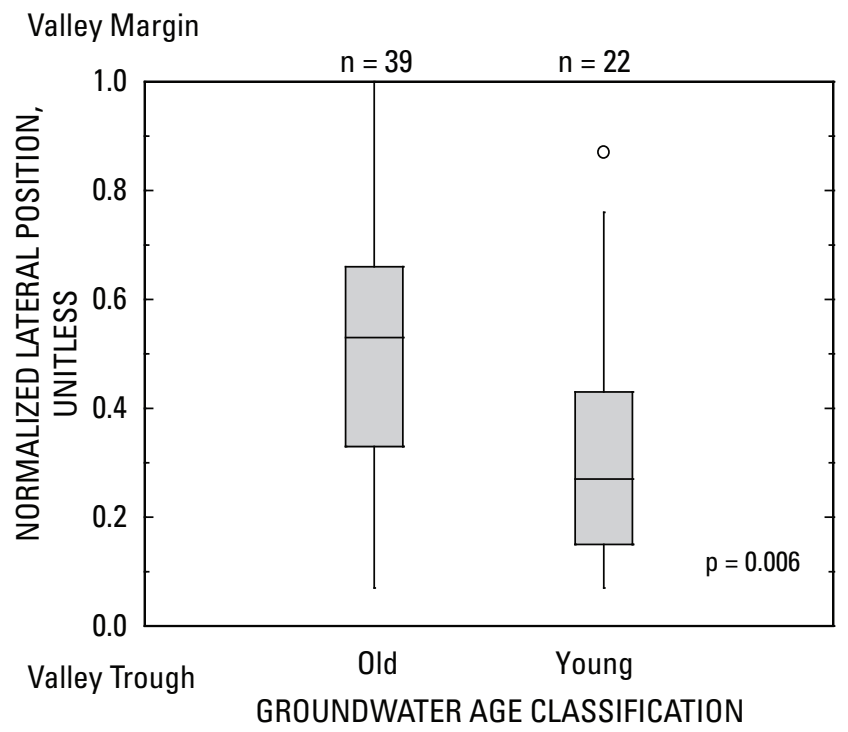

Figure 10. Classified groundwater age related to depth to top-of-perforation, well depth, and normalized lateral position, Northern San Joaquin Basin Groundwater Ambient Monitoring and Assessment (GAMA) study unit. 
Table 6. Results of Wilcoxon tests for differences in values of selected water-quality constituents and potential explanatory factors between young and old groundwater-age classification, wells with depths to top-of-perforation less than 200 feet and those equal to or greater than 200 feet, and wells with oxic conditions versus those with anoxic conditions, Northern San Joaquin Basin Groundwater Ambient Monitoring and Assessment (GAMA) study unit.

[p-values calculated using the Wilcoxon rank-sum tests, using exact distribution, with continuity correction. p-values less than 0.05 are defined as significant. Young defined as a well with a tritium concentration greater than or equal to 1 tritium unit (TU) and old defined as a well with a tritium concentration less than 1 TU. Shallow defined as wells with depths to top-of-perforation less than 200 feet below land surface and deep defined as wells with depths to top-ofperforation greater than or equal to 200 feet. Eastern Study Areas include the Cosumnes, Eastern San Joaquin, and Upland study areas of the Northern San Joaquin Basin study unit; nc, count can not be calculated; SMCL, secondary maximum contaminant level; bold text, significant correlation (p-value less than $0.05) ;<$ less than; > greater than]

\begin{tabular}{ccc} 
p-values from Wilcoxon rank-sum tests and significant differences \\
\hline $\begin{array}{c}\text { Groundwater age } \\
\text { (young, old) }\end{array}$ & $\begin{array}{c}\text { Depth to top-of- } \\
\text { perforation } \\
\text { (shallow, deep) }\end{array}$ & $\begin{array}{c}\text { Redox condition } \\
\text { (oxic, anoxic) }\end{array}$ \\
\hline
\end{tabular}

\begin{tabular}{|c|c|c|c|}
\hline \multicolumn{4}{|c|}{ Potential explanatory factors } \\
\hline Tritium & $\mathrm{nc}$ & 0.002 shallow $>$ deep & 0.944 \\
\hline $\mathrm{pH}$ & 0.857 & 0.319 & 0.375 \\
\hline Depth to top-of-perforations & 0.006 young $<$ old & nc & 0.522 \\
\hline Well depth & 0.378 & nc & 0.638 \\
\hline \multicolumn{4}{|c|}{ Inorganic constituents with health-based benchmarks } \\
\hline Arsenic & 0.038 young $>$ old & 0.003 shallow $>$ deep & 0.160 \\
\hline Arsenic - Eastern Study Areas & 0.086 & 0.032 shallow $>$ deep & 0.241 \\
\hline Boron & 0.055 & 0.057 & 0.062 \\
\hline Nitrate plus nitrite, as nitrogen & 0.558 & 0.643 & $<0.001$ oxic $>$ anoxic \\
\hline Gross alpha radioactivity ${ }^{1}$ & 0.008 young $>$ old & 0.419 & 0.207 \\
\hline \multicolumn{4}{|c|}{ Inorganic constituents with non-health-based benchmarks (SMCLs) } \\
\hline Chloride & 0.638 & 0.453 & 0.009 oxic $<$ anoxic \\
\hline Iron & 0.822 & 0.753 & $<0.001$ oxic $<$ anoxic \\
\hline Manganese & 0.462 & 0.767 & $<0.001$ oxic $<$ anoxic \\
\hline Sulfate & 0.539 & 0.197 & 0.140 \\
\hline Total dissolved solids & 0.739 & 0.389 & 0.950 \\
\hline Total dissolved solids - Eastern Study Areas & 0.005 young $>$ old & 0.093 & 0.257 \\
\hline \multicolumn{4}{|c|}{ Organic constituent classes with health-based benchmarks } \\
\hline Sum of total trihalomethane (TTHM) concentrations ${ }^{1}$ & $<0.001$ young $>$ old & $\mathrm{nc}$ & 0.080 \\
\hline Sum of solvent concentrations ${ }^{1}$ & $<0.001$ young $>$ old & nc & nc \\
\hline Sum of fumigant concentrations ${ }^{1}$ & 0.001 young $>$ old & $\mathrm{nc}$ & nc \\
\hline Sum of pesticide concentrations ${ }^{1}$ & $<0.001$ young $>$ old & nc & 0.963 \\
\hline
\end{tabular}

${ }^{1}$ Grid wells only. Variables not footnoted include grid plus understanding wells.

Tritium concentrations were significantly higher (indicating younger water) in those wells with depths to top-of-perforation of less than $200 \mathrm{ft}$ (table 6). Groundwater classified as young was most often located closer to the valley trough than groundwater classified as old (fig. 10C, table 6), possibly because of infiltration of young irrigation water in the San Joaquin Valley and because wells closer to the valley trough tend to be shallower than those in the upland areas (fig. 11). 


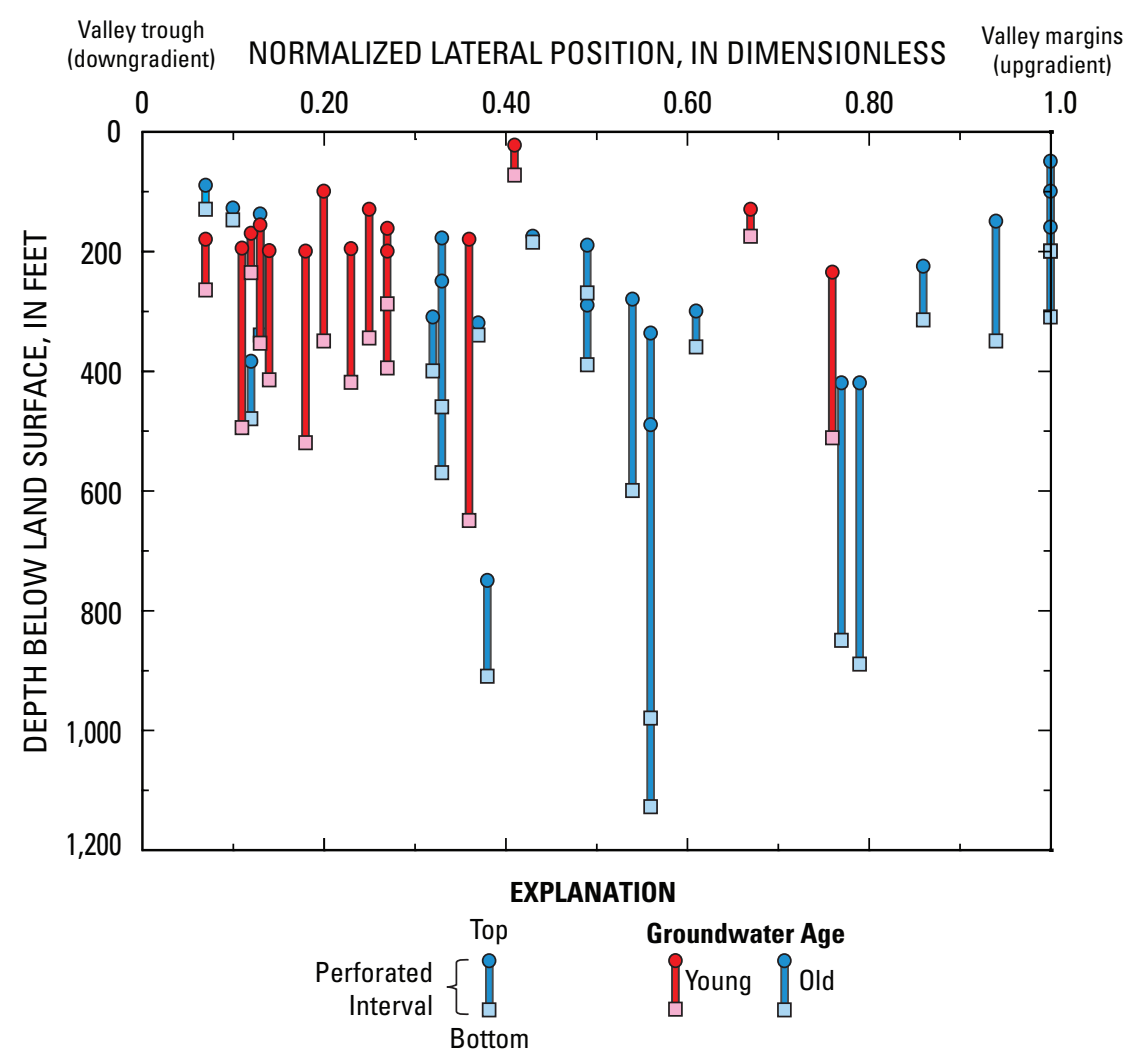

Figure 11. Relation of classified groundwater age to normalized lateral position and depth of perforated interval of wells, Northern San Joaquin Basin Groundwater Ambient Monitoring and Assessment (GAMA) study unit.

\section{Geochemical Conditions}

Groundwater samples were classified as oxic (oxygen reducing) or anoxic (nitrate, manganese, iron, or sulfate reducing) based on the available data. The classification of groundwater samples is based on the relative-concentrations of redox-sensitive constituents (appendix B). Groundwater in the Northern San Joaquin Basin study unit primarily was classified as oxic (54 percent of wells). Anoxic conditions occurred in 20 of the 61 wells evaluated (33 percent). Anoxic conditions primarily occurred in the central and western parts of the study unit (valley trough and deltaic locations) (fig. 12). Previous investigations have noted that groundwater typically becomes more reducing towards the trough of the San Joaquin Valley (Davis and others, 1959; Bertoldi and others 1991; Dubrovsky and others, 1993; Chapelle and others, 1995; Burow and others, 1998b). Analysis of the relation between redox conditions and normalized lateral position of the wells indicates that waters classified as anoxic tend to occur closer to the valley trough, and wells classified as oxic tend to occur closer to the valley margin; however, the relation was not statistically significant (fig. 13, table 6). 


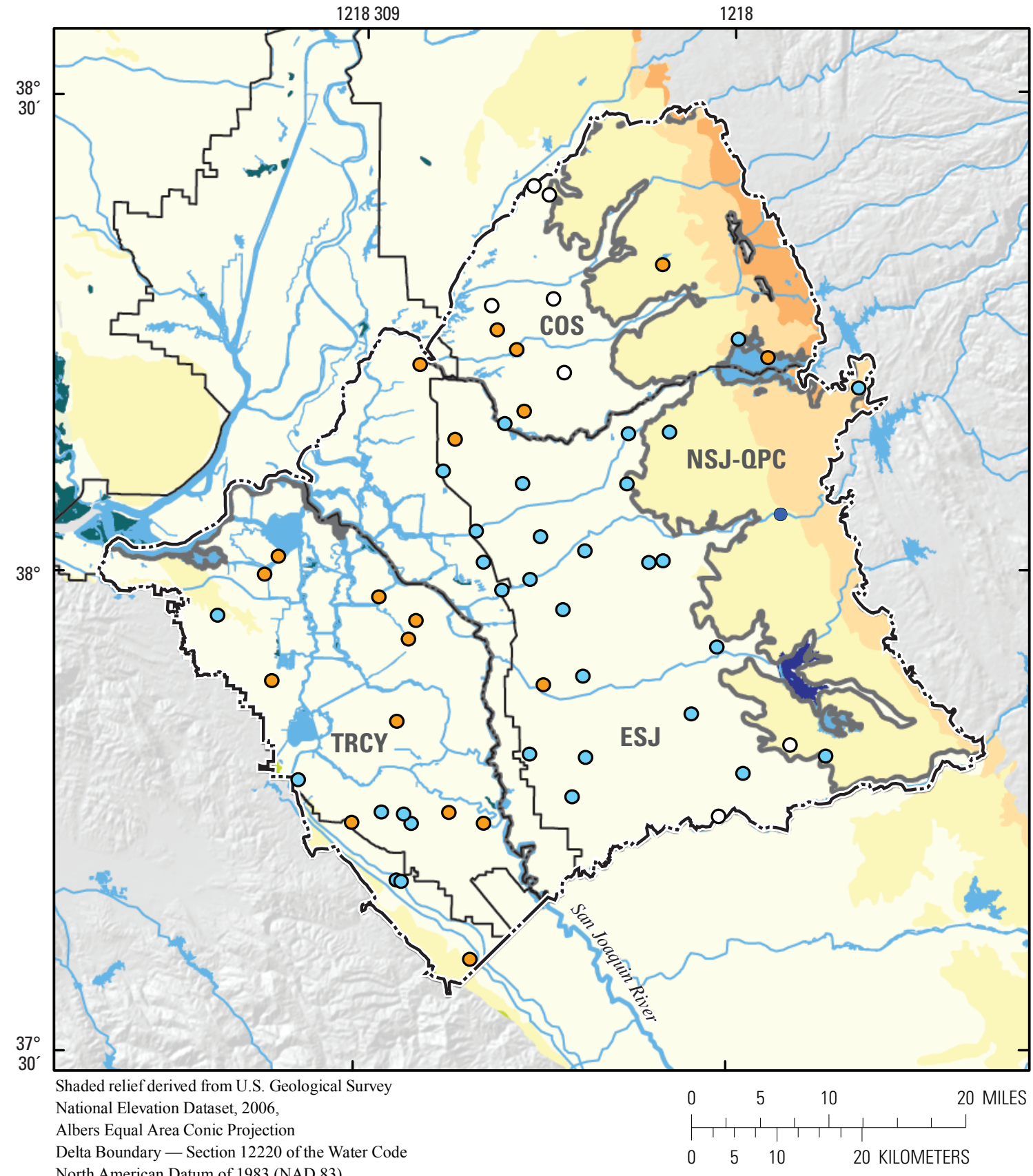

Delta Boundary - Section 12220 of the Water Code North American Datum of 1983 (NAD 83)

\section{Geologic units}

Quaternary alluvium (Q)

Quaternary/Plio-Pleistocene semi-consolidated (QPC)

M iocene nonmarine consolidated (MC)

Eocene nonmarine consolidated (EC)
EXPLANATION

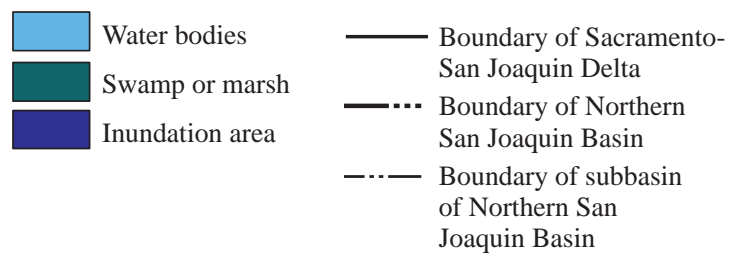

Redox Category

O Indeterminate

O Anoxic

O Oxic

Study areas

Cosumnes (COS)

Eastern San J oaquin (ESJ)

U plands (NS)-QPC)

Tracy (TRCY)

Figure 12. Redox conditions in grid and understanding wells, Northern San Joaquin Basin Groundwater Ambient Monitoring and Assessment (GAMA) study unit. Classification of redox category based on framework developed by McMahon and Chapelle (2008), which uses measurements of redox-sensitive constituents (dissolved oxygen, nitrate, iron, manganese, and sulfate) to determine redox conditions. Wells labeled as indeterminate had insufficient data for classification. 

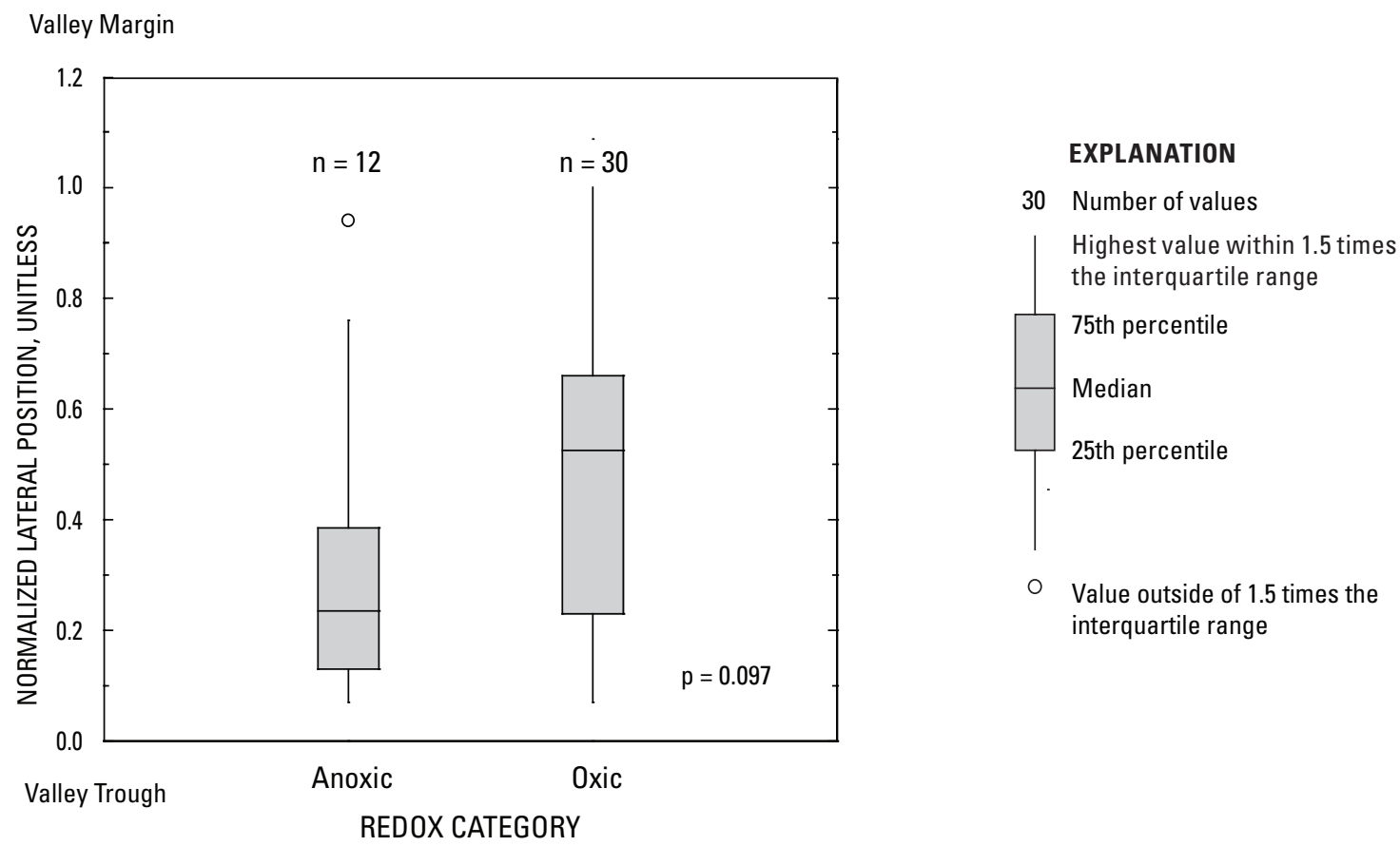

Figure 13. Classified redox category to normalized lateral position, Northern San Joaquin Basin Groundwater Ambient Monitoring and Assessment (GAMA) study unit.

\section{Correlations Between Explanatory Factors}

If two explanatory factors are statistically related, that relation can result in a spurious relation between one of those explanatory factors and a dependent variable. Identification of such correlations between explanatory factors therefore is important for the correct interpretation of statistical relations between explanatory factors and the occurrence or distribution of water-quality constituents. Using the grid well dataset, significant correlations between explanatory factors were seen in 9 of 21 comparisons made and are noted below with the exception of the relation between groundwater age and depth, which was discussed earlier (table 7). Implications of correlations between explanatory factors are discussed in section, "Status and Understanding of Water Quality," as part of the analysis of factors affecting individual constituents.

Because the three land-use types necessarily sum to 100 percent, the land-use types are expected to be inversely correlated and this is seen in the significant negative correlations between urban and agricultural land use and agricultural and natural land use (table 7). The percentages of urban and agricultural land use were significantly negatively correlated to normalized lateral position from the valley trough, although the percentage of natural land use was significantly positively correlated to normalized lateral position (table 7). The correlation between urban and agricultural land use and normalized lateral position is related to the fact that urban and agricultural land uses are located closer to the center of the basin, with the largest urban area (the city of Stockton) situated along the San Joaquin River in the center of the basin and surrounded by agricultural land use (fig. 6). Additionally, the percentage of urban land use was significantly positively correlated to $\mathrm{pH}$ and the depth of wells below land surface. Normalized lateral position was significantly negatively correlated with $\mathrm{pH}$. Depth to top-of-perforation and well depth are auto-correlated as was expected. 
Table 7. Results of non-parametric (Spearman's rho method) analysis of correlations in grid wells between selected potential explanatory factors, Northern San Joaquin Basin Groundwater Ambient Monitoring and Assessment (GAMA) study unit.

[Spearman's rho test used and rho values shown. Significance level $(\mathrm{p}<0.05)$; Correlations with $r h o>0.2$ and $\mathrm{p}$-values $<0.05$ are shown in bold; $<$, less than; >, greater than]

\begin{tabular}{|c|c|c|c|c|c|c|c|}
\hline rho & $\begin{array}{c}\text { Percentage of } \\
\text { urban } \\
\text { land use }\end{array}$ & $\begin{array}{c}\text { Percentage of } \\
\text { agricultural } \\
\text { land use }\end{array}$ & $\begin{array}{c}\text { Percentage of } \\
\text { natural } \\
\text { land use }\end{array}$ & $\begin{array}{c}\text { Normalized } \\
\text { lateral } \\
\text { position }\end{array}$ & $\begin{array}{l}\text { Depth to top- } \\
\text { of-perforation }\end{array}$ & Well depth & $\mathbf{p H}$ \\
\hline $\begin{array}{c}\text { Percentage of } \\
\text { urban } \\
\text { land use }\end{array}$ & & -0.409 & -0.118 & -0.206 & 0.124 & 0.322 & 0.376 \\
\hline $\begin{array}{c}\text { Percentage of } \\
\text { agricultural } \\
\text { land use }\end{array}$ & & & -0.720 & -0.291 & 0.133 & -0.181 & 0.025 \\
\hline $\begin{array}{c}\text { Percentage of } \\
\text { natural } \\
\text { land use }\end{array}$ & & & & 0.481 & 0.067 & 0.159 & -0.160 \\
\hline $\begin{array}{c}\text { Normalized } \\
\text { lateral } \\
\text { position }\end{array}$ & & & & & 0.027 & 0.039 & -0.483 \\
\hline $\begin{array}{l}\text { Depth to top- } \\
\text { of-perforation }\end{array}$ & & & & & & 0.642 & -0.152 \\
\hline Well depth & & & & & & & -0.186 \\
\hline $\mathrm{pH}$ & & & & & & & \\
\hline
\end{tabular}

\section{Status and Understanding of Water Quality}

As a starting point for summarizing the results of about 11,000 individual analytical results for the Northern San Joaquin Basin study unit, the maximum relativeconcentrations of the individual constituents and constituent groups were compared to each other (fig. 14). All constituents shown have health-based benchmarks, except for those in the group inorganic-SMCL, which have non-health-based aesthetic benchmarks. Constituents with moderate or high maximum relative-concentrations are discussed individually. Aquifer proportions calculated by the grid-based approach were considered the most reliable and are used in the subsequent discussions, except where otherwise noted. In some instances, the spatially weighted approach identified constituents that could be present at moderate or high relative-concentrations in small proportions of the primary aquifer that were not identified using the grid-based approach. Results from the spatially weighted approach were only used in cases for which the grid-based approach was found to have this limitation. Non-significant relations generally are not discussed; selected significant correlations are shown graphically.

Most of the detected organic and special-interest constituents ( 32 of $40 ; 80$ percent) have some type of health-based benchmark (table 8). Three of the detected constituents (deethylatrazine, 2,6-diethylaniline,

3,4-dichloroanaline) on the pesticide schedules and for which no health-based benchmarks exist are degradates of pesticides that do have health-based benchmarks (atrazine, alachlor, and propanil, respectively). 


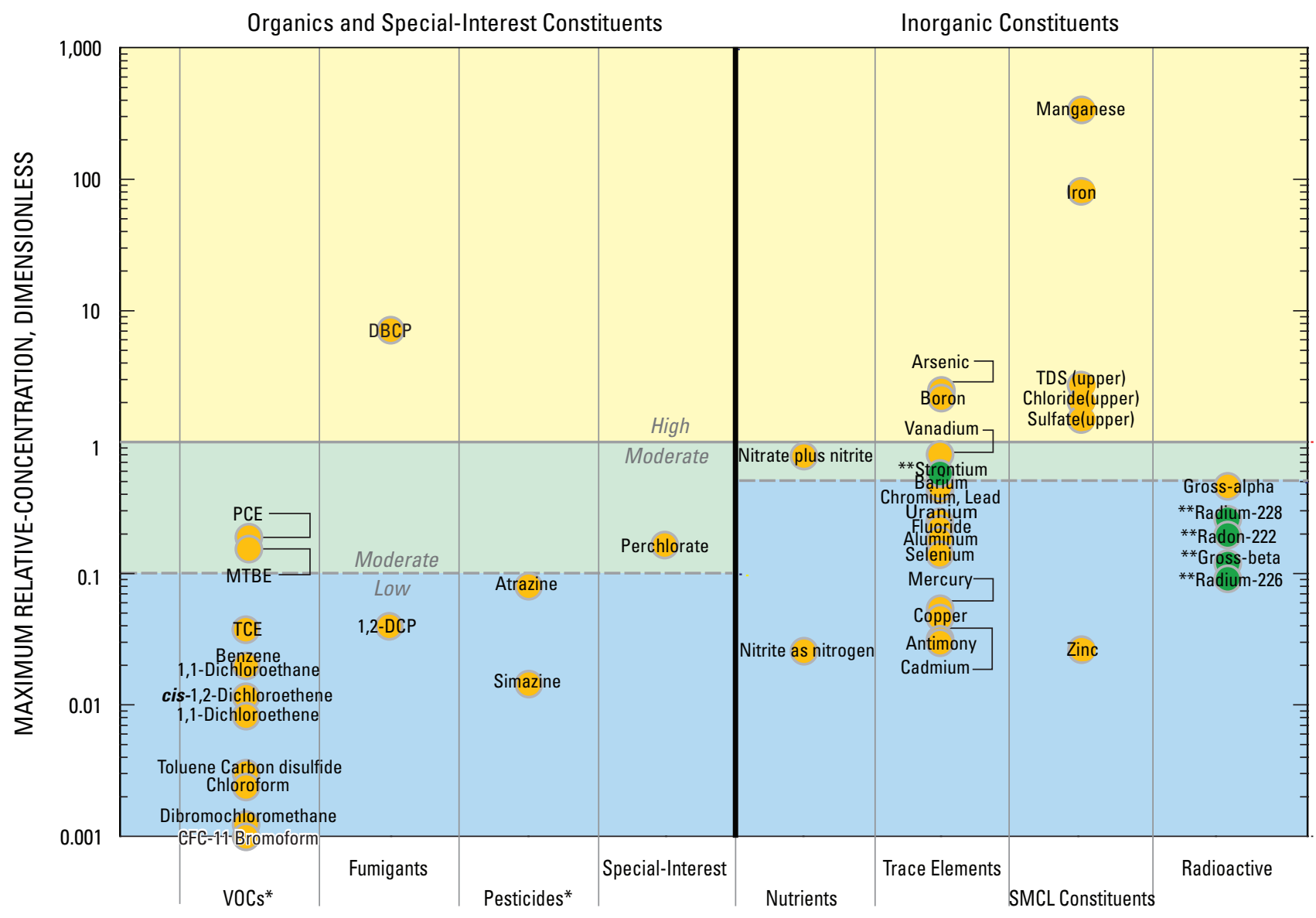

EXPLANATION

Relative-Concentration

\begin{tabular}{|l}
$\square$ High \\
\hline$\square$ Moderate \\
\hline$\square$ Low
\end{tabular}

PCE Constituents with analyses in $>20$ grid wells and wells are spatially representative -

Name and center of symbol is location of data unless indicated by following location line:

Strontium Constituents with analyses in $\mathbf{2 0}$ grid wells and wells are not spatially representative -

Name and center of symbol is location of data unless indicated by following location line:

\section{Abbreviations}

VOC, volatile organic compound; TCE, trichloroethene; PCE, tetrachloroethene; DBCP, 1,2-dibromo-3-chloropropane 1,2-DCP,

1,2-dichloropropane; SMCL, secondary maximum contaminant level; MTBE, methyl tert-butyl ether; TDS, total dissolved solids; upper, upper water-quality benchmark where multiple benchmarks exist.

* Seven VOCs and four pesticides were detected at relative-concentrations less than 0.001 and are not shown on the figure.

**Constituents with less than 20 sample results.

Figure 14. Maximum relative-concentration in grid wells for constituents detected by type of constituent, Northern San Joaquin Basin Groundwater Ambient Monitoring and Assessment (GAMA) study unit. 
In contrast to organic and specialinterest constituents, almost all inorganic and radioactive constituents were detected at least once (44 of $48 ; 91$ percent) (table 8). Health-based or aesthetic (those with SMCLs) benchmarks are not available for about one-third of the measured inorganic and radioactive constituents (13 of 48; 27 percent). Most of the constituents without benchmarks are major or minor ions that are naturally present in groundwater.

Aquifer-scale proportions were computed using spatially weighted and grid-based approaches (table 9). Constituents of interest were those with (1) high relativeconcentrations during the full period of record of the Northern San Joaquin Basin CDPH database (January 10, 1984-April $21,2004)$, and (2) constituents selected in the grid-based assessment on the basis of moderate to high relative-concentrations or, for organic constituents, detection frequencies greater than 10 percent (table 9). Raw detection frequencies also are provided for comparison. Five constituentschloroform, 1,1,2,2-tetrachloroethane, cadmium, gross beta radioactivity, and uranium (table 3) - were detected in $\mathrm{CDPH}$ wells at high relative-concentrations prior to the 3-year period used for the status assessment (historically high constituents). Individual constituents were grouped into constituent classes - specifically, inorganic constituents with health-based benchmarks, inorganic constituents with aesthetic [secondary maximum contaminant level (SMCL)] benchmarks, and organic constituents with health-based benchmarks (table 10). For each constituent or constituent class meeting the criteria for analysis of explanatory factors, relations to explanatory factors are described in subsections for the constituent class (table 11).
Table 8. Number of constituents analyzed and detected by health-based benchmark type and constituent type, Northern San Joaquin Basin Groundwater Ambient Monitoring and Assessment (GAMA) study unit.

[Health-based benchmarks include U.S. Environmental Protection Agency (USEPA) and California Department of Public Health (CDPH) maximum contaminant levels, USEPA lifetime health advisory levels and risk-specific dose level at $10^{-5}$ lifetime cancer risk, and CDPH notification level. Abbreviations: SMCL, secondary maximum contaminant level (non-health based); VOC, volatile organic compound]

\begin{tabular}{lcc}
\hline \multicolumn{1}{c}{ Benchmark type } & $\begin{array}{c}\text { Number of } \\
\text { constituents } \\
\text { analyzed }\end{array}$ & $\begin{array}{c}\text { Number of } \\
\text { constituents } \\
\text { detected }\end{array}$ \\
\hline VOCs plus gasoline oxygenates & & \\
\hline Health-based benchmarks & 50 & 20 \\
No benchmark & 25 & 2 \\
$\quad$ Total: & 75 & 22 \\
\hline Fumigants & & 2 \\
Health-based benchmarks & 9 & 0 \\
No benchmark $\quad 1$ & 2 \\
$\quad$ Total: & 10 & 2 \\
\hline
\end{tabular}

\section{Pesticides and degradates}

Health-based benchmarks

No benchmark

Total:

\begin{tabular}{rr}
40 & 9 \\
85 & 6 \\
125 & 15 \\
\hline
\end{tabular}

\section{Special-interest constituents}

Health-based benchmarks

No benchmark

Total:

\begin{tabular}{ll}
3 & 1 \\
0 & 0 \\
3 & 1 \\
\hline
\end{tabular}

Sum of organic and special-interest constituents (all categories above)

\begin{tabular}{lrr}
\hline Health-based benchmarks & 102 & 32 \\
No benchmark & 111 & 8 \\
$\quad$ Total: & 213 & 40 \\
\hline
\end{tabular}

\section{Sum of inorganic and radioactive constituents}

\begin{tabular}{lrr}
\hline Health-based benchmarks & 29 & 27 \\
SMCL & 6 & 5 \\
No benchmark & 13 & 12 \\
$\quad$ Total: & 48 & 44 \\
\hline
\end{tabular}




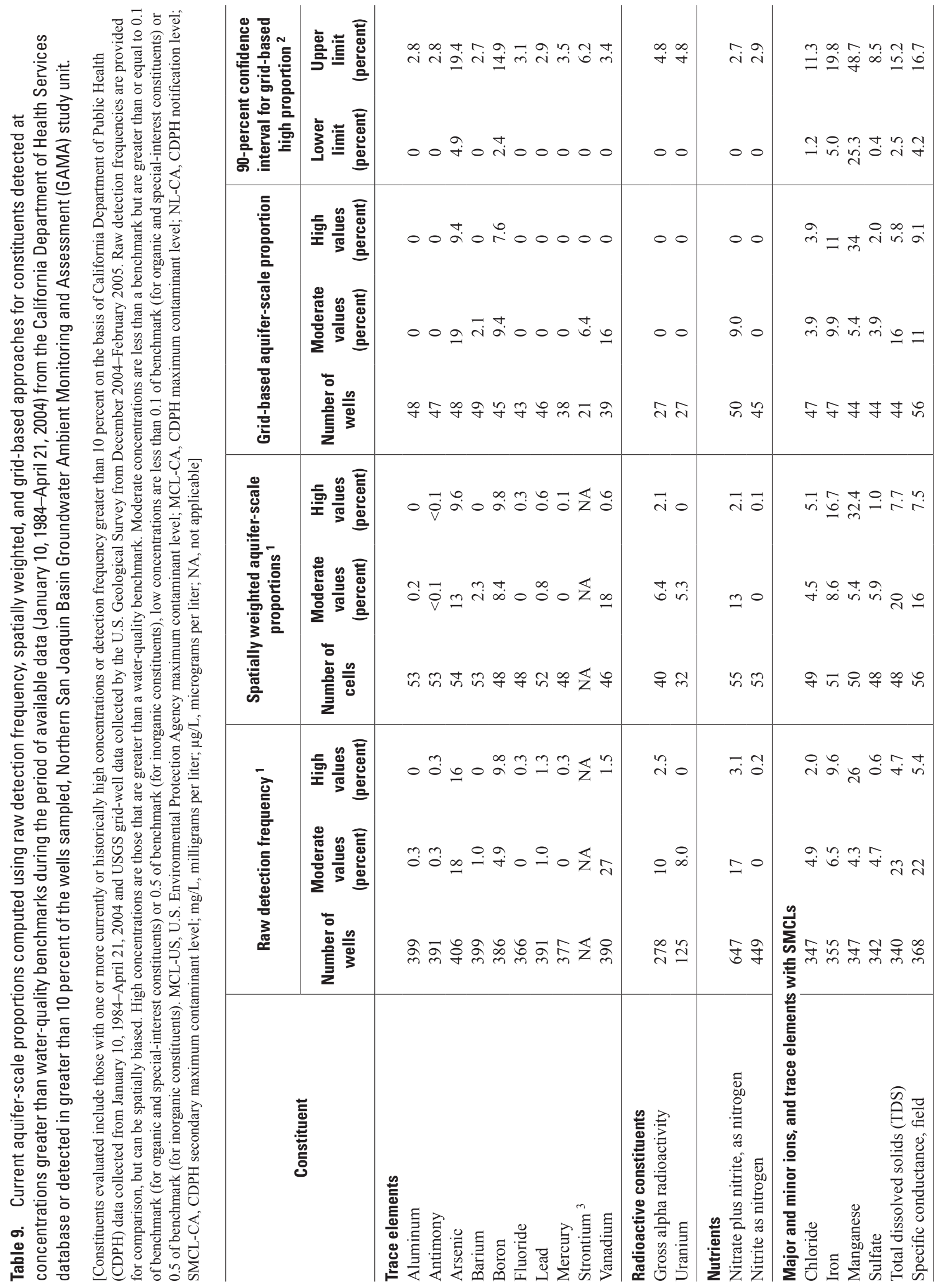




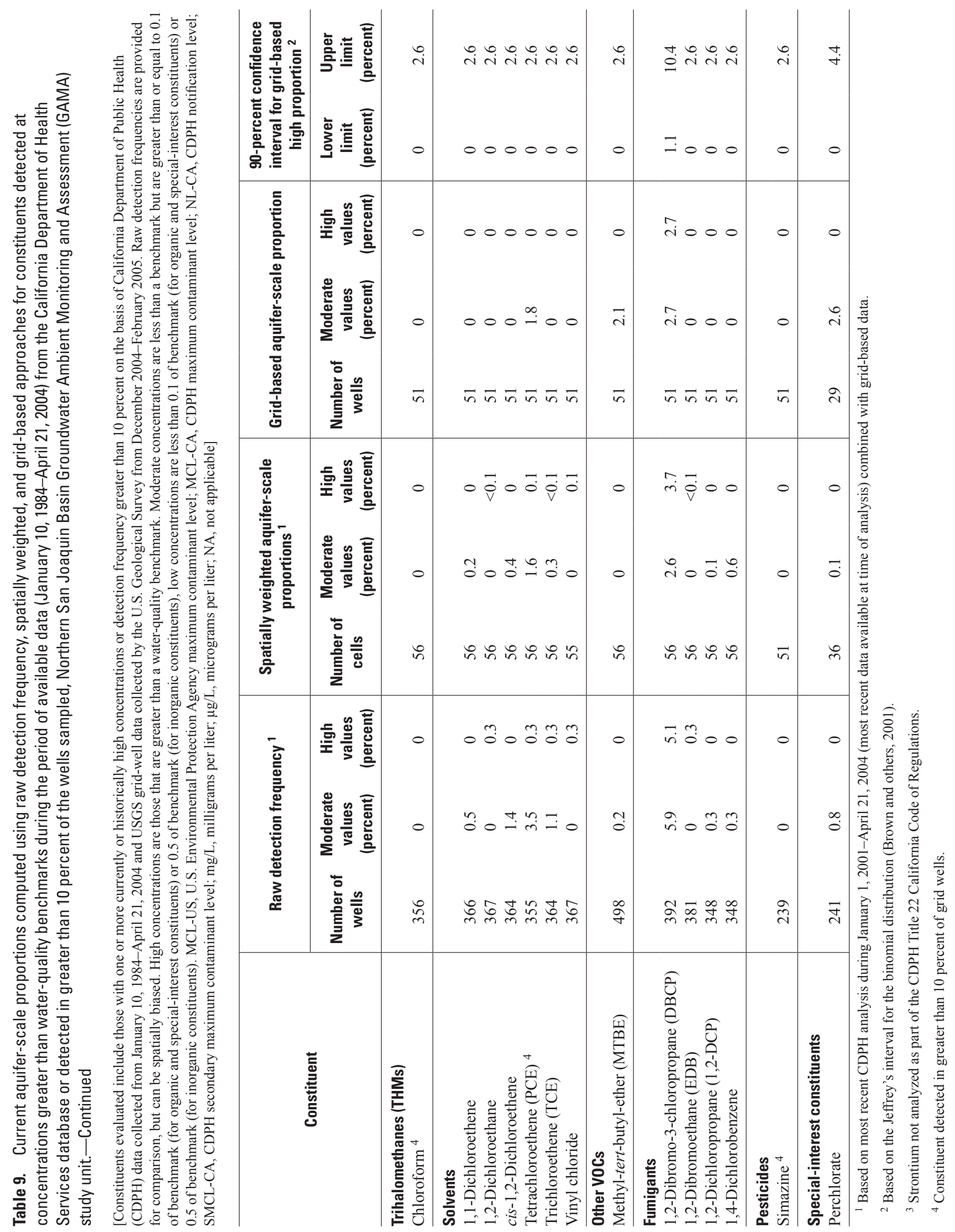


Table 10. Aquifer-scale proportions for constituent classes, Northern San Joaquin Basin Groundwater Ambient Monitoring and Assessment (GAMA) study unit.

[SMCL, secondary maximum contaminant level; VOCs, volatile organic compounds; all values greater than 10 percent are rounded to the nearest 1 percent, values less than 10 percent are rounded to the nearest 0.1 percent; rounding of values may result in proportions for a class not adding up to 100 percent]

\begin{tabular}{|c|c|c|c|}
\hline & \multicolumn{3}{|c|}{ Aquifer-scale proportion (percent) } \\
\hline & $\begin{array}{c}\text { Low } \\
\text { values }\end{array}$ & $\begin{array}{c}\text { Moderate } \\
\text { values }\end{array}$ & $\begin{array}{c}\text { High } \\
\text { values }\end{array}$ \\
\hline \multicolumn{4}{|c|}{ Inorganic constituent classes with health-based benchmarks } \\
\hline Trace elements & 62 & 25 & 13 \\
\hline Nutrients & 89 & 9 & 22.1 \\
\hline Radioactive constituents & 98 & 0 & ${ }^{2} 2.1$ \\
\hline Any inorganic with health-based benchmarks & 58 & 29 & 13 \\
\hline \multicolumn{4}{|c|}{ Inorganic constituents with SMCLs } \\
\hline Any inorganic with aesthetic benchmarks & 33 & 31 & 36 \\
\hline \multicolumn{4}{|c|}{ Organic constituent classes with health-based benchmarks } \\
\hline Total trihalomethanes (TTHMs) & 100 & 0 & 0 \\
\hline Solvents & 98 & 1.8 & ${ }^{2} 0.1$ \\
\hline Other VOCs & 98 & 2.1 & ${ }^{2} 0.1$ \\
\hline Fumigants & 95 & 2.7 & 2.7 \\
\hline Pesticides & 100 & 0 & 0 \\
\hline Any organic with health-based benchmarks & 90 & 6.9 & 2.7 \\
\hline
\end{tabular}




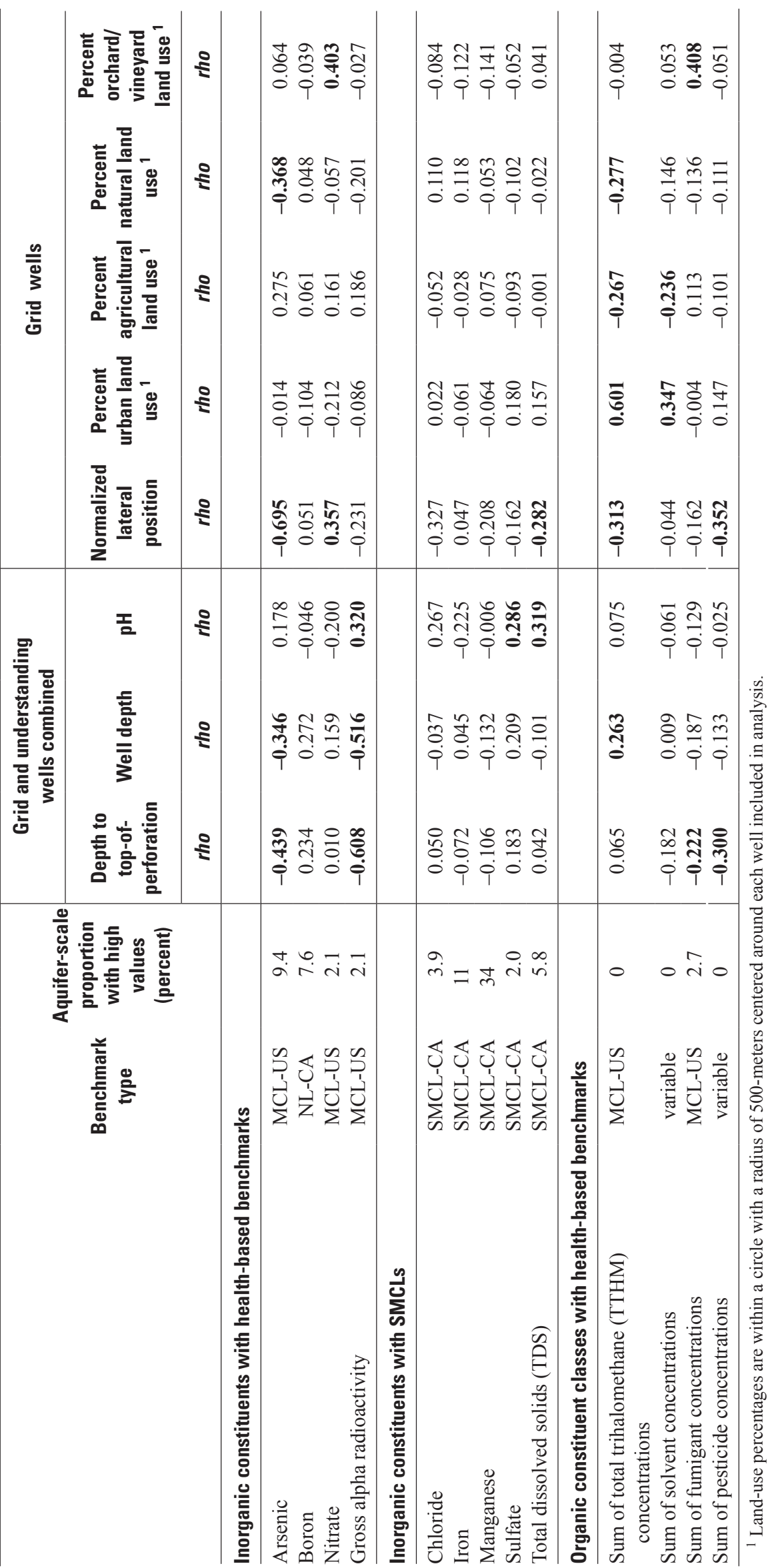




\section{Inorganic Constituents}

Inorganic constituents as a group were the largest contributor to high and moderate relative-concentrations throughout the Northern San Joaquin Basin study unit. Relative-concentrations for 11 inorganic constituents were greater than 0.5 based on the grid-based approach (fig. 14) the trace elements arsenic, barium, boron, strontium, and vanadium; the nutrient nitrate; the major and minor elements chloride, iron, and manganese; sulfate; and total dissolved solids (TDS) [measured directly or calculated from specific conductance (see appendix C)]. In addition, relativeconcentrations of gross alpha radioactivity were greater than 2 percent based on the spatially weighted approach (table 9). Analysis of potential explanatory factors is included for those constituents with relative-concentrations greater than 1specifically, arsenic, boron, gross alpha radioactivity, nitrate, chloride, iron, manganese, sulfate, and TDS.

Inorganic constituents with health-based benchmarks (nutrients, trace elements, and radioactive constituents) were assessed by using the grid-based approach. Relativeconcentrations of at least one constituent were high for 13-percent, moderate for 29 percent, and low for 58 percent of the primary aquifer (table 10). The proportion of the primary aquifer with high relative-concentrations of inorganic constituents as a class was equivalent to the proportion of the primary aquifer with high relative-concentrations of trace elements because no nutrient or radioactive constituent was detected at high relative-concentrations.

\section{Trace Elements}

Trace elements as a group were the largest contributor to high relative-concentrations in the inorganic constituent class. Relative-concentrations of at least one trace element with health-based benchmarks were high for 13 percent, moderate for 25 percent, and low for 62 percent of the primary aquifer (table 10).

The trace elements mercury, fluoride, lead, and vanadium were detected at high relative-concentrations in the primary aquifer using the spatially weighted approach but were not high using the grid-based approach; however, proportions of the primary aquifer with high relative-concentrations of mercury, fluoride, lead, and vanadium were $0.1,0.3,0.6$, and 0.6 percent, respectively (table 9). Relative-concentrations for each of these trace elements were high in at least one well in the CDPH data for January 1, 2001-April 21, 2004. These detections reflect high relative-concentrations of these constituents in a very small proportion of the primary aquifer.

Arsenic relative-concentrations were high in 9.4 percent and moderate in 19 percent of the primary aquifer (table 9 , fig. 15A). Arsenic relative-concentrations were high and moderate in the Cosumnes, Eastern San Joaquin, and Tracy study areas, but not in the Upland study area (figs. 15A and $\underline{16 A}$ ). Arsenic is a naturally occurring semi-metallic trace element commonly associated with sulfide minerals and deposits of metal ores, such as copper and gold (Welch and others, 2006). Industrially, arsenic is most commonly used as a wood preservative, but also can be used in paints, dyes, metals, drugs, soaps, semi-conductors, and in the mining of copper and gold (U.S. Environmental Protection Agency, 2009).

Boron relative-concentrations were high in 7.6 percent and moderate in 9.4 percent of the primary aquifer (table 9). Boron relative-concentrations were high in grid wells in the western part of the Tracy study area (fig. 16B). Boron relative-concentrations were moderate primarily in the Tracy study area, with one well with a moderate relativeconcentration in the Eastern San Joaquin study area (fig. 16B). Boron is a trace element that occurs in many minerals, principally borax; it is mined principally in California and Turkey. Boron is an essential plant nutrient in small amounts; however, large amounts can be harmful or even toxic to some plants (Hem, 1992). Boron has numerous uses, including glass and silicate production, fire retardants, laundry and cleaning products, and insecticides.

\section{Factors Affecting Arsenic}

Arsenic concentrations in the Northern San Joaquin Basin study unit are related to geochemical conditions in the primary aquifer, which vary with depth, groundwater age, and normalized lateral position. Arsenic concentrations in samples with a groundwater age classified as young and collected from wells with a depth to the top-of-perforation of less than $200 \mathrm{ft}$ were significantly higher than samples with a groundwater age classified as old based on tritium concentrations or samples from wells with a depth to top-of-perforation of greater than $200 \mathrm{ft}$ (table 6). Arsenic concentrations also were correlated (negatively) with normalized lateral position and percentage of natural land use (table 11), indicating an increase in arsenic concentrations with increased proximity to the valley trough. 
A.

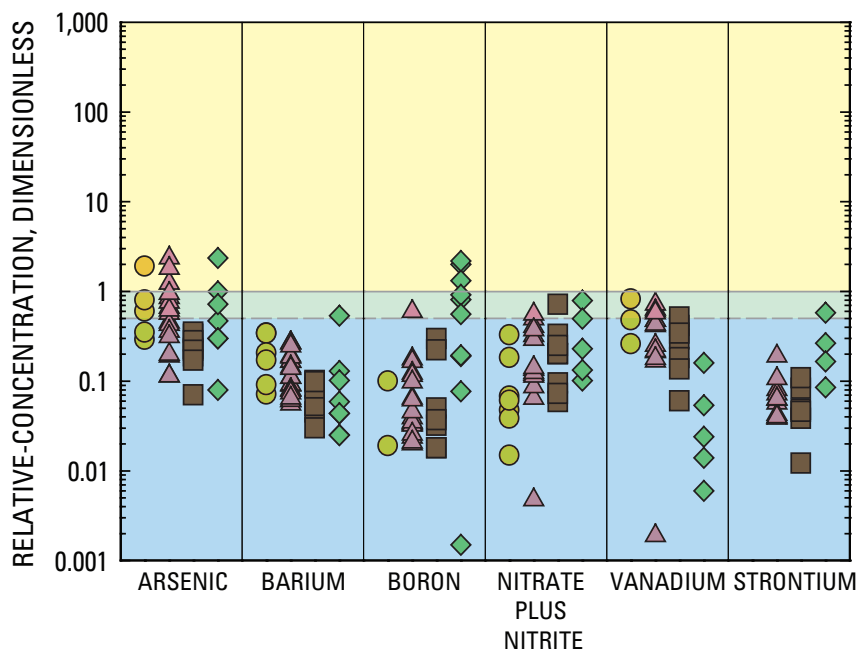

B.

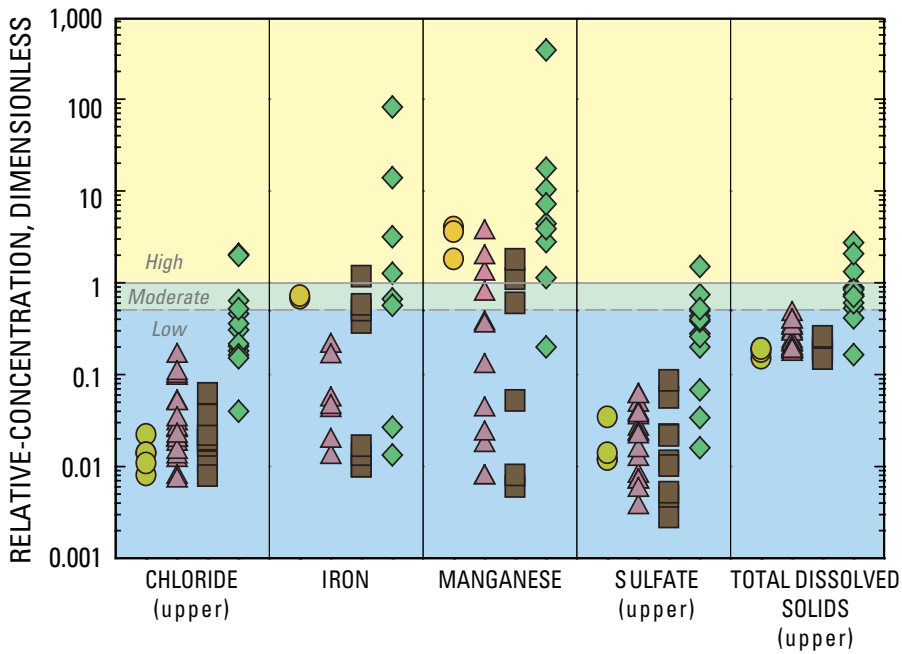

EXPLANATION

Relative-Concentration

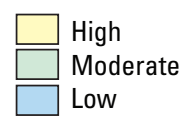

(upper), upper water-quality benchmark where multiple benchmarks exist
Study Areas

Cosumnes

$\triangle$ Eastern San Joaquin

$\square$ Uplands

$\diamond$ Tracy

Figure 15. Relative-concentrations of trace elements and nutrients with health-based benchmarks and maximum relativeconcentrations greater than 0.5 in grid wells, and major and minor elements with aesthetic benchmarks and maximum relative-concentrations greater than 0.5 in grid wells, Northern San Joaquin Basin Groundwater Ambient Monitoring and Assessment (GAMA) study unit.

Results from this study can be compared to results of work conducted by Izbicki and others (2008). In their study of the sources and distribution of arsenic in the Eastern San Joaquin Groundwater Basin, arsenic concentrations were not uniformly distributed areally or with depth, but generally were low (less than the maximum contaminant level of $10 \mu \mathrm{g} / \mathrm{L}$ ) in the eastern part of the study area near recharge areas and were high (greater than $10 \mu \mathrm{g} / \mathrm{L}$ ) near the margin of the Sacramento-San Joaquin Delta. Results reported by Izbicki and others (2008) indicate that arsenic concentrations generally increase with well depth (opposite of what was observed in this report), but that arsenic concentrations in samples from wells within the high-arsenic areas near the margin of the Delta commonly were greater than $10 \mu \mathrm{g} / \mathrm{L}$ regardless of well depth, and that arsenic in water from wells in the eastern part of the study area were not correlated with depth. In the study presented here, an inverse correlation with depth can be attributed to low arsenic concentrations in deep (> $700 \mathrm{ft}$ ) wells sampled in the southern part of the Tracy study area (fig. 17A). When arsenic concentrations are compared to well depths, excluding the results from the Tracy study area, there is no significant correlation.

Previous investigations of arsenic in the San Joaquin Valley (Belitz and others, 2003; Welch and others, 2006; Izbicki and others, 2008) and literature reviews (Stollenwerk, 2003; Welch and others, 2006) have attributed elevated arsenic in groundwater in the eastern San Joaquin Valley primarily to two mechanisms. One is the release of arsenic resulting from reductive dissolution of iron or manganese oxyhydroxides under iron- or manganese-reducing conditions. Dissolved arsenic also can increase from $\mathrm{pH}$-dependent desorption of arsenic from aquifer sediments under oxic conditions. This tends to occur in groundwater with $\mathrm{pH}$ greater than 7.5 (Stollenwerk, 2003). 


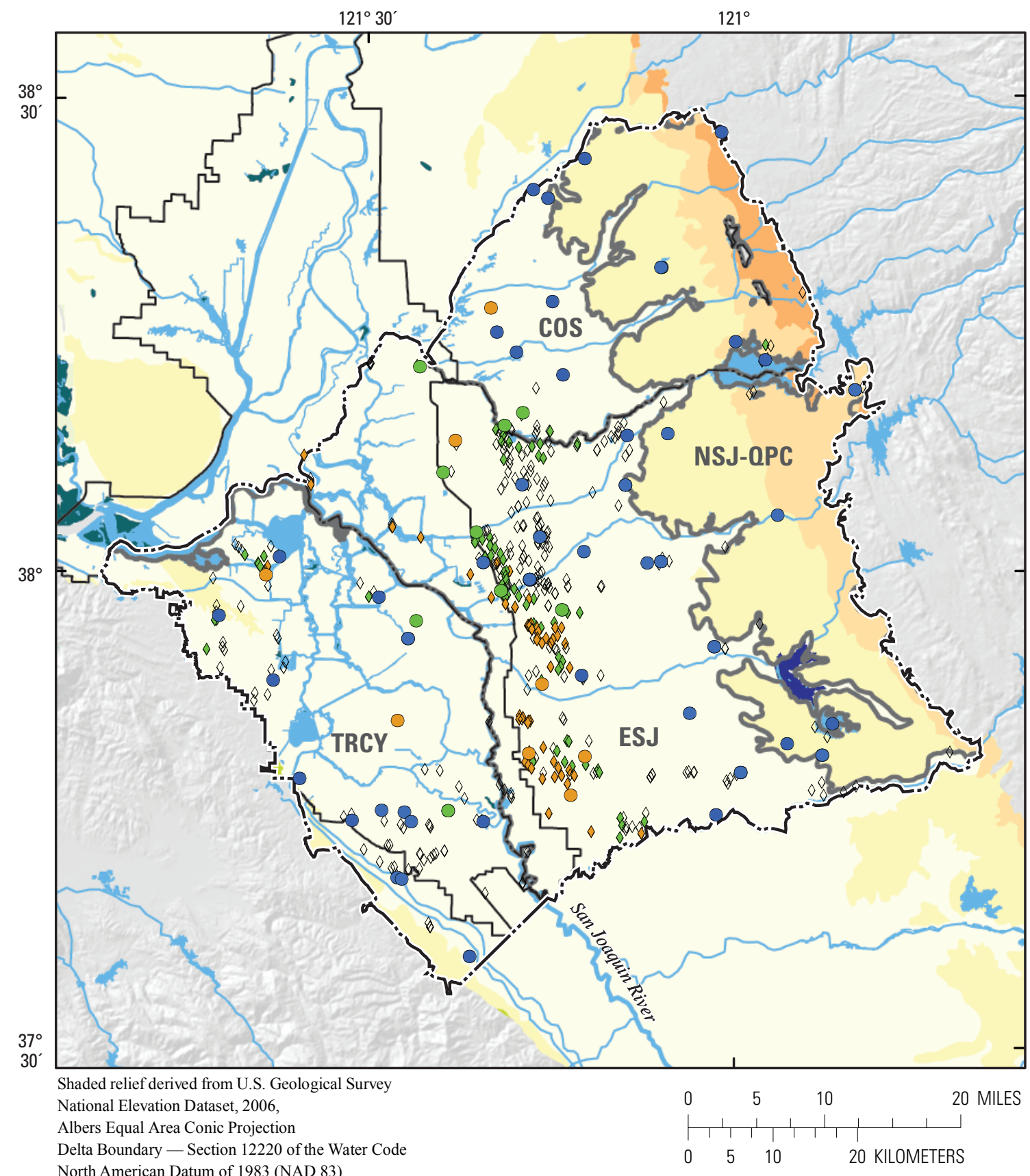

A. Arsenic

\section{Geologic units}

Quaternary alluvium (Q)

Quaternary/Plio-Pleistocene semi-consolidated (QPC)

M iocene nonmarine consolidated (MC)

Eocene nonmarine consolidated (Ec)

\section{EXPLANATION}

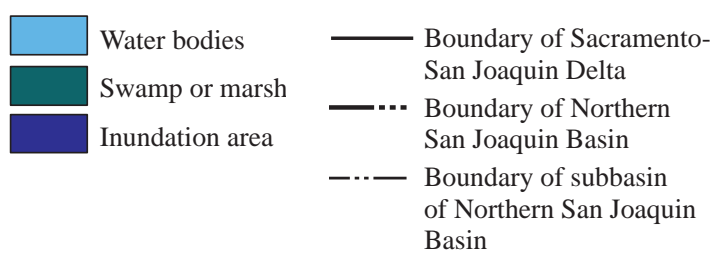

Relative-Concentration

Grid and U nderstanding CDPH Wells Wells $\diamond$ Low

- Low $\diamond$ Moderate

$\bigcirc$ M oderate $\quad \diamond$ High

O High

Study areas

Cosumnes (COS)

Eastern San J oaquin (ESJ)

U plands (NSJ-QPC)

Tracy (TRCY)

Figure 16. Relative-concentrations of selected inorganic constituents for USGS-grid and USGS-understanding wells, and relativeconcentrations from the most recent inorganic constituent data point from the "prior period" (January 1, 2001-April 21, 2004) for CDPH wells, Northern San Joaquin Basin Groundwater Ambient Monitoring and Assessment (GAMA) study unit. 


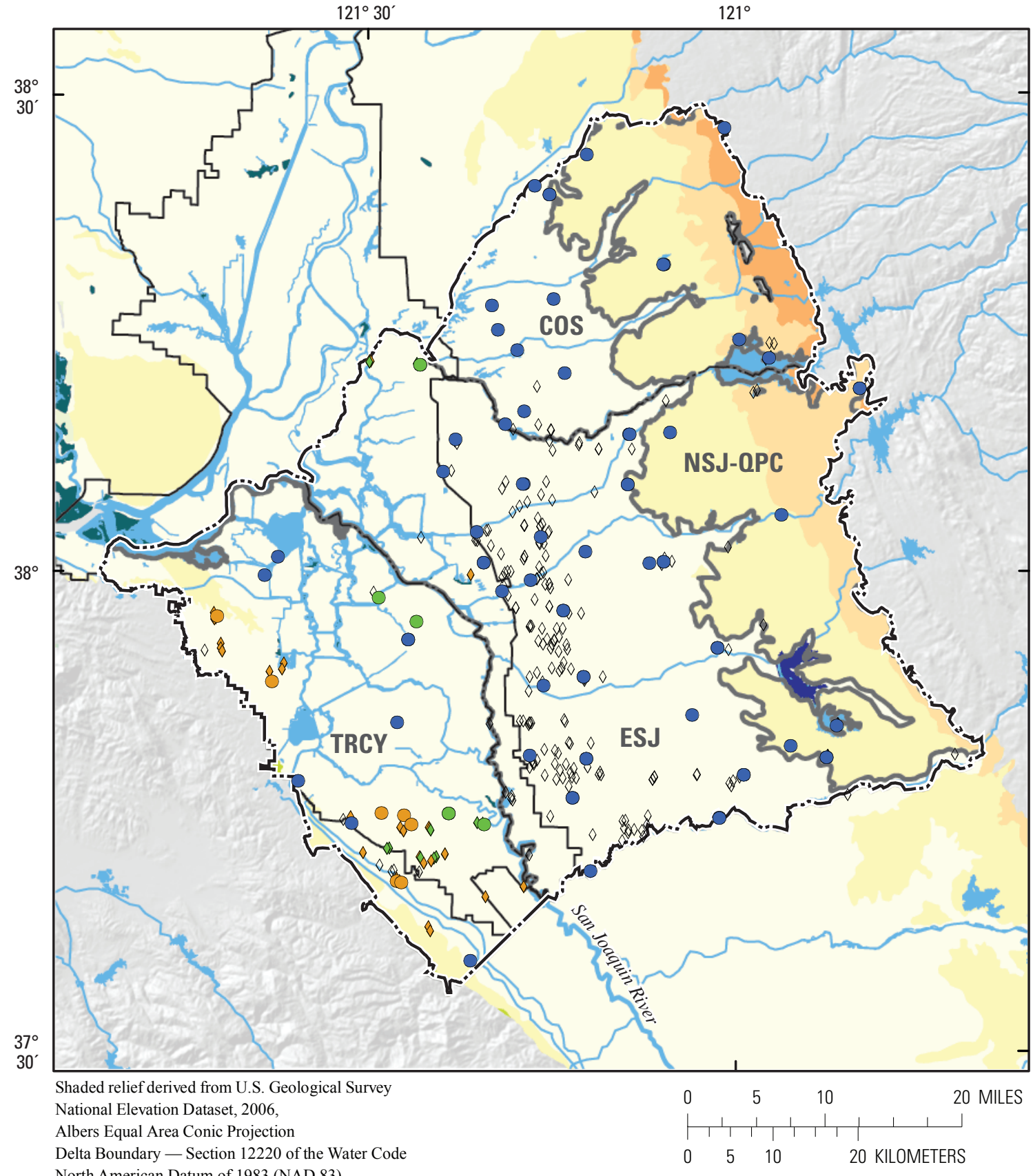

B. Boron

Figure 16.-Continued 


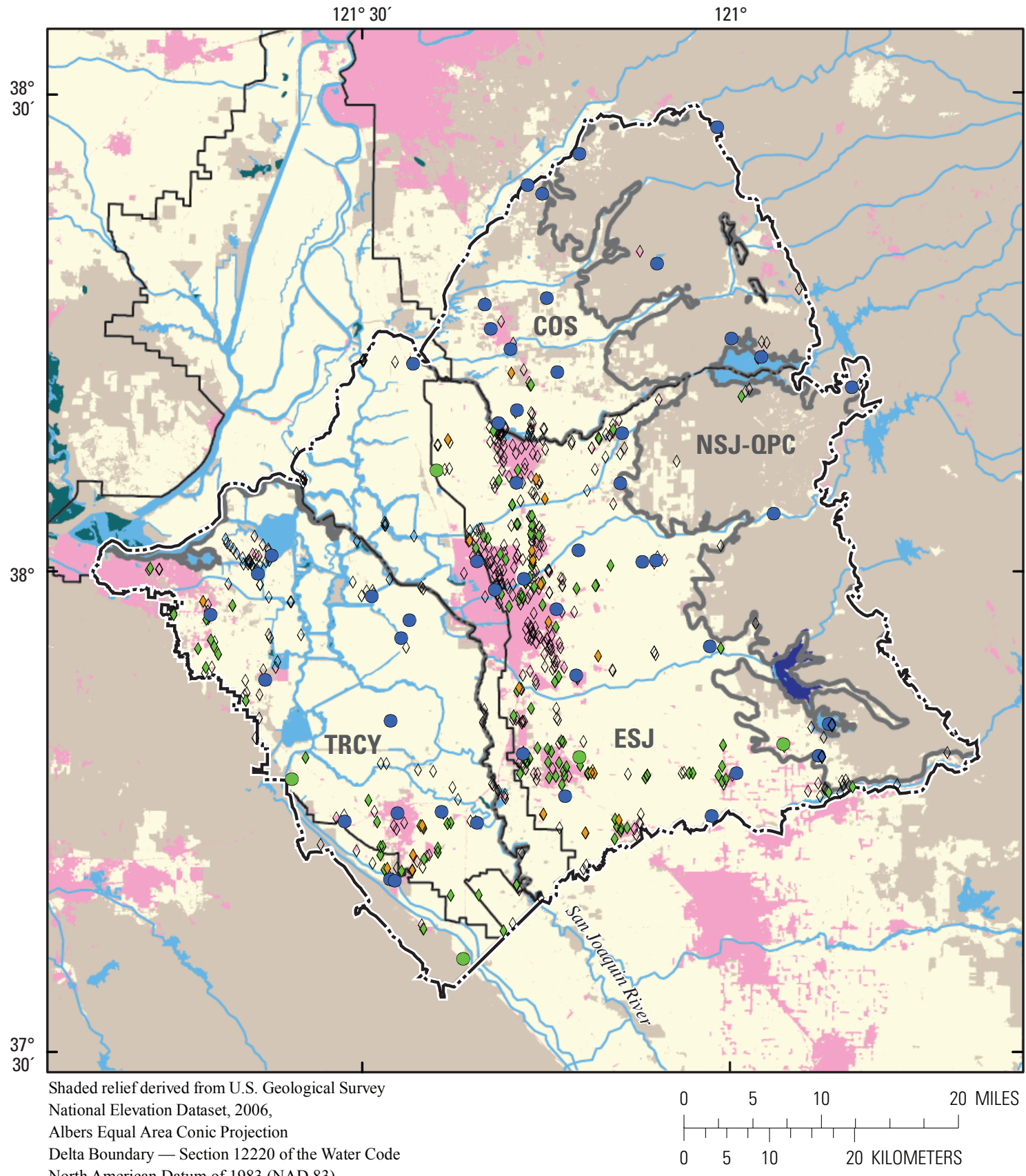

C. Nitrate

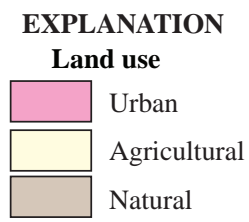

Figure 16.-Continued 


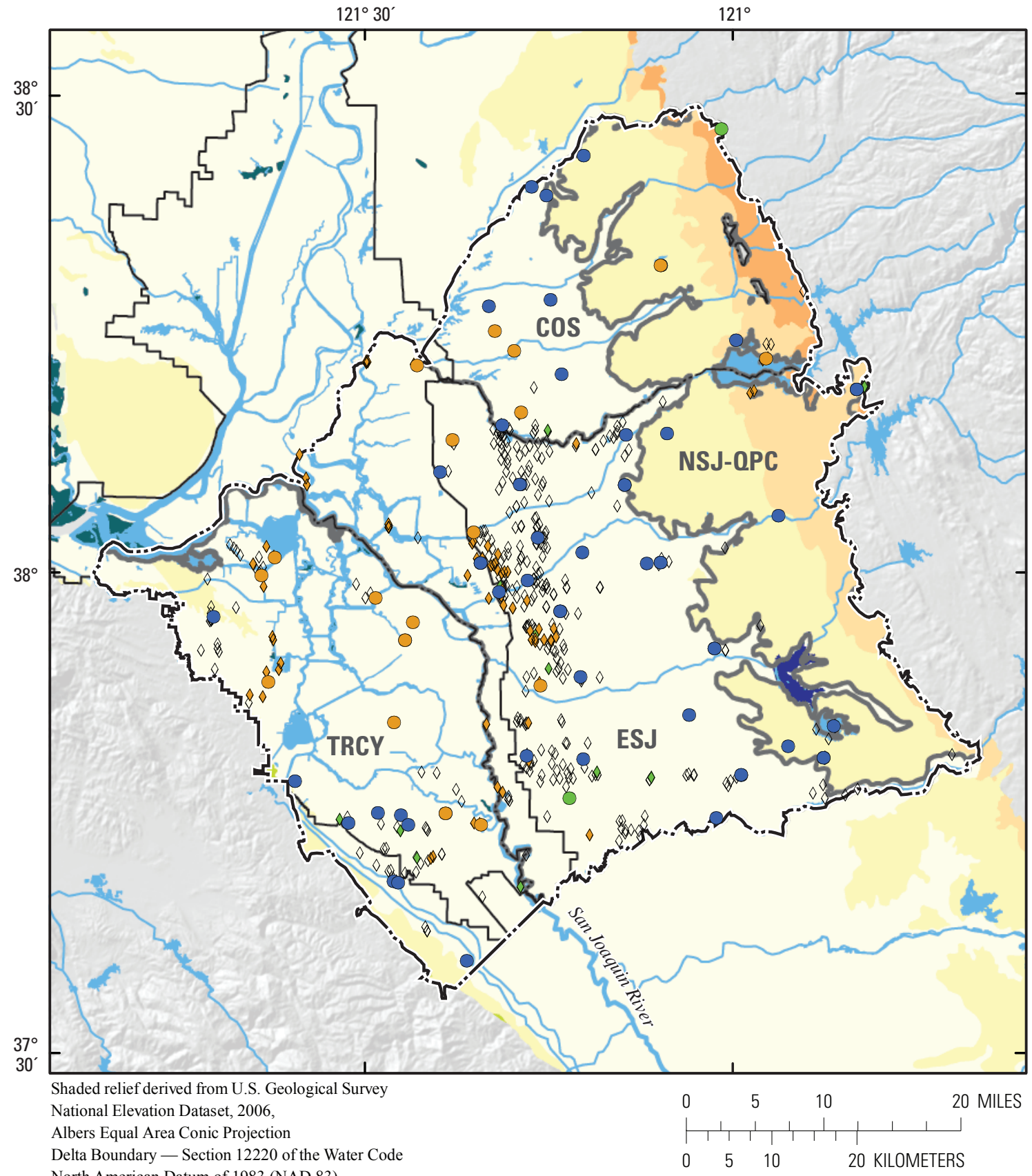

D. Manganese

Figure 16.-Continued 


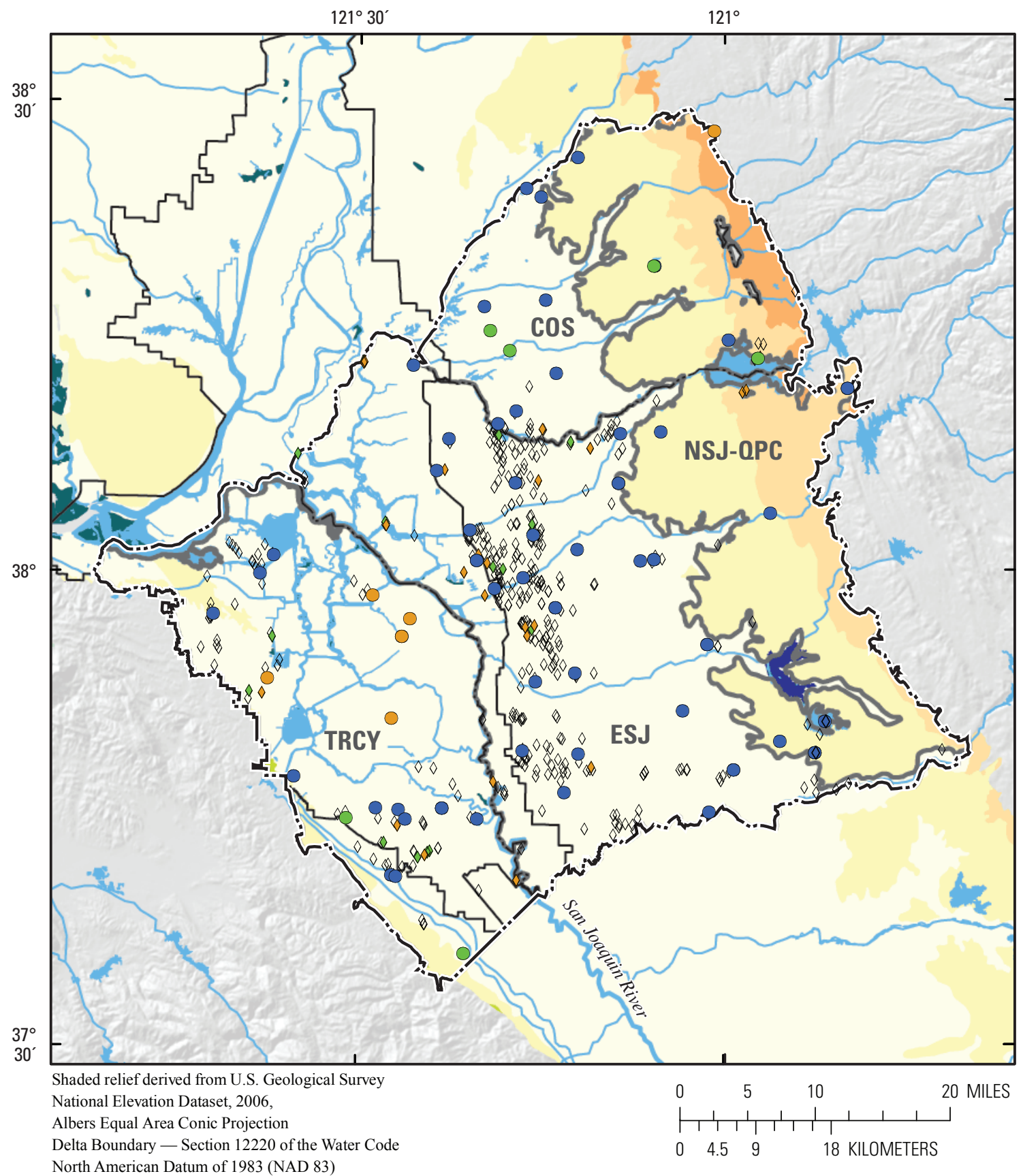

E. Iron

Figure 16.-Continued 


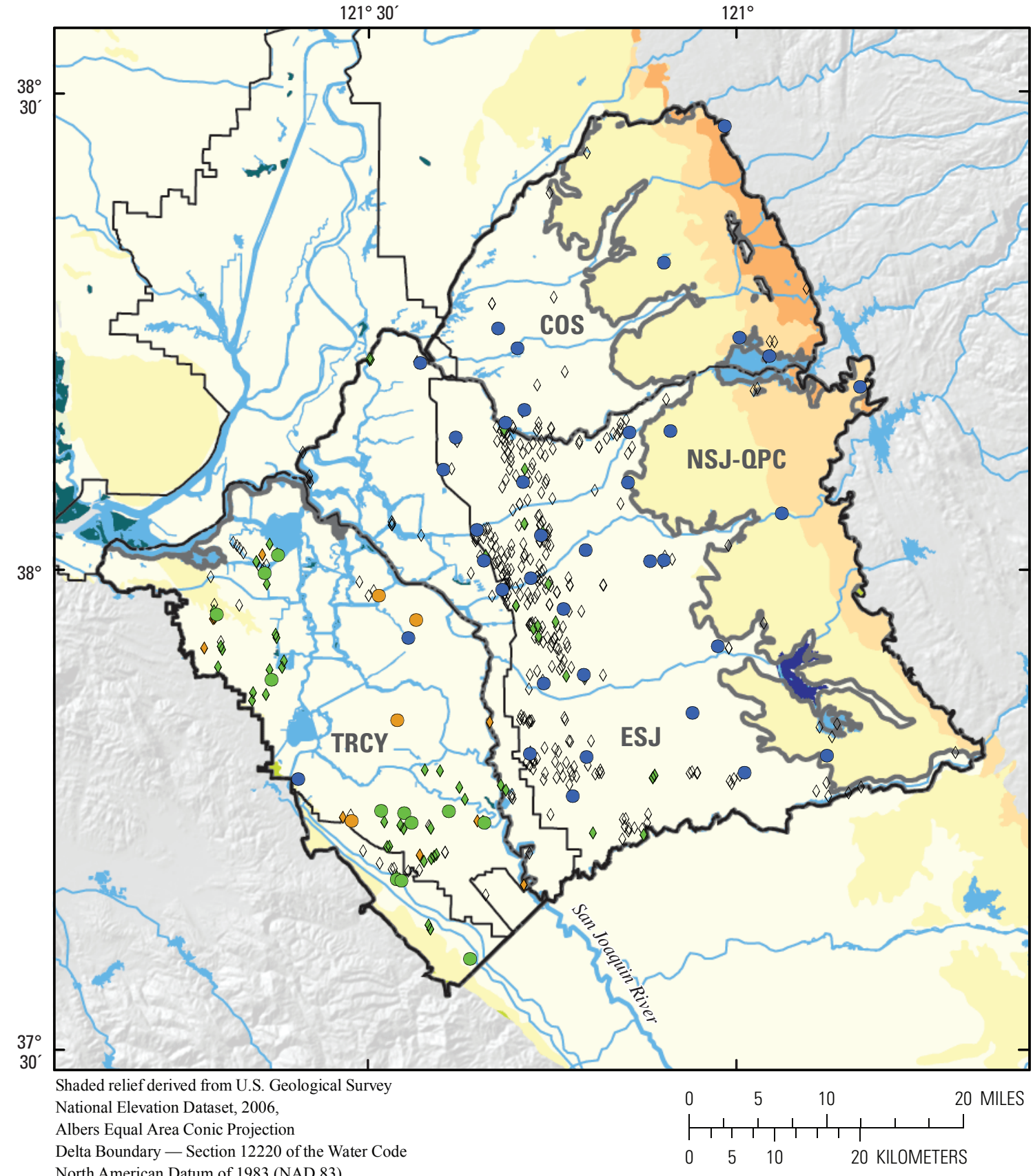

F. Total dissolved solids

Figure 16.-Continued 


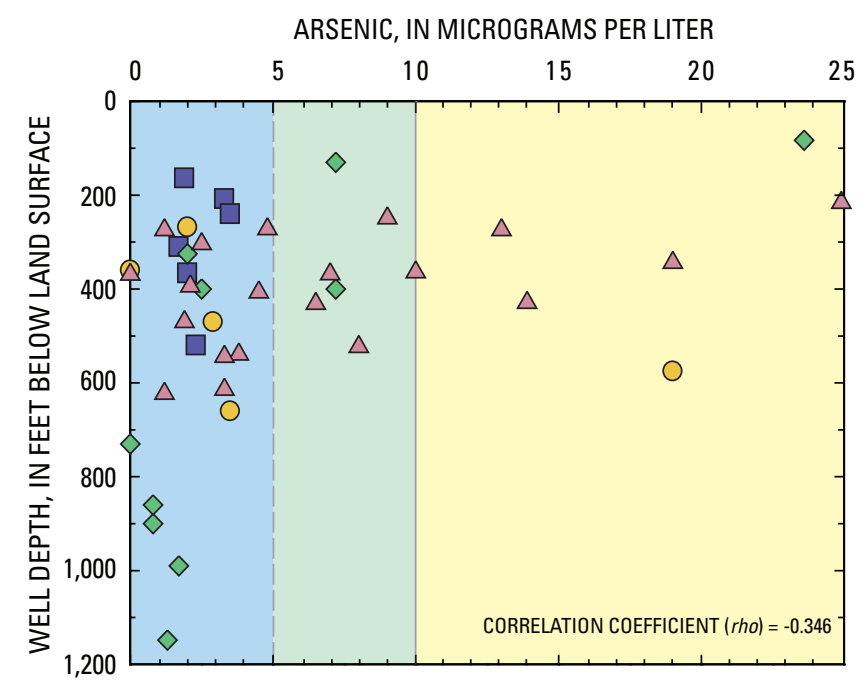

A. Well depth

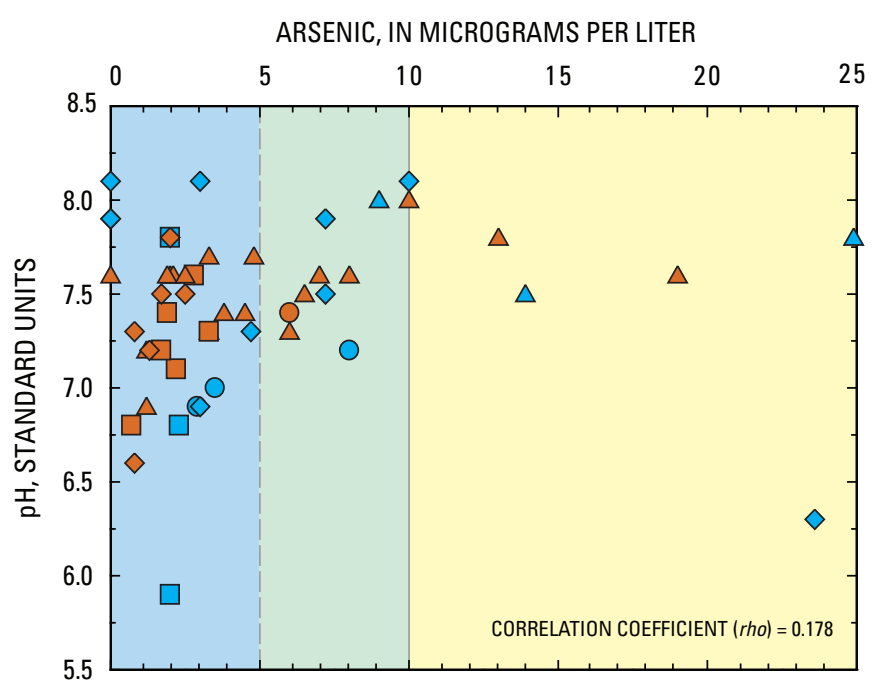

B. $\mathrm{pH}$ and redox condition

EXPLANATION

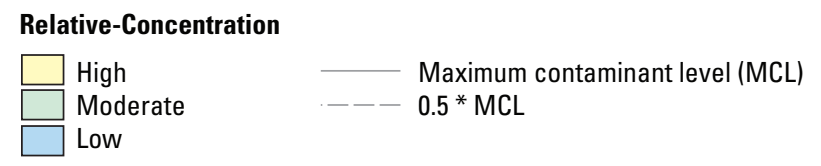

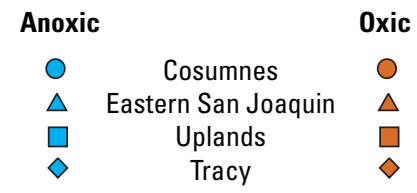

Figure 17. Relation of arsenic to well depth and $\mathrm{pH}$ and redox condition, Northern San Joaquin Basin Groundwater Ambient Monitoring and Assessment (GAMA) study unit.

Elevated concentrations of arsenic in the Northern San Joaquin Basin study unit can be attributed to both processes discussed in the previous studies. Concentrations of arsenic generally increase, although not significantly, as $\mathrm{pH}$ increases $(\mathrm{p}=0.2$, rho $=0.17$, table 11$)$. Four of the five high relativeconcentrations of arsenic occur equal to or greater than a $\mathrm{pH}$ of 7.5 (fig. 17B). Reductive dissolution of arsenic also can be inferred in that for any given $\mathrm{pH}$, arsenic concentrations are higher in anoxic wells than in oxic wells (fig. 17B $)$.

\section{Factors Affecting Boron}

Concentrations of boron are highest in the westernmost parts of the Tracy study area (fig. 16B). Boron concentrations were not significantly correlated with any of the explanatory factors explored in this study (table 11) and there was no significant differences in boron concentrations between waters with different age or redox categories (table 6).

Because high and moderate relative-concentrations of boron were limited to the western part of the study unit, elevated concentrations of boron relative to the rest of the study unit appear to be associated with sediments in the aquifer derived from marine deposits, which are naturally high in boron, and which are contained within the Coast Ranges on the western flank of the study unit. Saline waters, which also contain relatively high concentrations of boron (Hem, 1992), and which once permeated these marine sediments have migrated into adjacent and overlying continental deposits (Page, 1986). Boron concentrations were significantly positively correlated with concentrations of TDS ( $\mathrm{p}=<0.01$, $r h o=0.54)$.

\section{Radioactive Constituents}

Constituents in the radioactive category in this study were gross alpha and beta radioactivity, radium isotopes, radon222 , and tritium. The only radioactive constituent detected at a high relative-concentration in any proportion of the primary aquifer was gross alpha radioactivity. Relative-concentrations of gross alpha radioactivity were high in 2.1 percent of the primary aquifer, as determined using the spatially weighted approach (table 9). Gross alpha radioactivity was not detected at high or moderate relative-concentrations using the grid-based approach. "However, samples from a limited number of wells in the grid-based approach were analyzed for gross alpha radioactivity ( 27 wells), which results in a 90-percent upper confidence level of 4.8 percent for gross alpha radioactivity for the grid-based approach. In other words, the grid-based approach has a reasonable chance of 
failing to detect high relative-concentrations of gross alpha radioactivity if relative-concentrations were high in less than 4.8 percent of the primary aquifer. None of the other radioactive constituents were detected at moderate or high relative-concentrations. Activities of gross alpha radioactivity were negatively correlated to depths to top-of-perforation and well depth (table 11). Gross alpha radioactivity also was positively correlated with $\mathrm{pH}$ (table 11).

\section{Nutrients}

Nutrients measured in this study were ammonia, nitrite plus nitrate (hereinafter referred to as nitrate), nitrite, total nitrogen, and orthophosphate. Ammonia, nitrate, and nitrite are the only nutrients measured that have health-based benchmarks, and they are grouped together as the nutrient class in this report. As a class, nutrient relative-concentrations were high in the primary aquifer equivalent to the proportion of high relative-concentrations of nitrate. Relative-concentrations of nitrate were high in 2.1 percent of the primary aquifer computed using the spatially weighted approach (tables 9 and $\underline{10}$ ). The spatially weighted result for the high proportion of nitrate in the primary aquifer is presented because grid-based results for high relative-concentrations of nitrate were zero. The aquifer proportion for high relative-concentrations of nitrate calculated using the spatially weighted approach were within the 90-percent confidence interval for the grid-based high aquifer proportion (table 9). The moderate proportion of nitrate relative-concentrations determined from the grid-based approach was 9.0 percent of the primary aquifer (tables 9 and $\underline{10})$.

Relative-concentrations of nitrate were high primarily in the central part of the Eastern San Joaquin and southern part of the Tracy study area (fig. 16C). Moderate relativeconcentrations were measured in the Eastern San Joaquin, Upland, and Tracy study areas (figure 15A and fig. 16C). The most significant source of nitrate to the environment is the application of fertilizers.

\section{Factors Affecting Nitrate}

Nitrate concentrations were significantly different when comparing samples in oxic and anoxic geochemical conditions, with concentrations significantly higher in oxic samples (table 6, fig. 18). Nitrate concentrations were positively correlated to normalized lateral position (table 11). Nitrate concentrations were not significantly correlated with percentage of agricultural land use; however, nitrate concentrations were correlated to the more specific agricultural land-use category defined by orchard and vineyard land use (table 11).

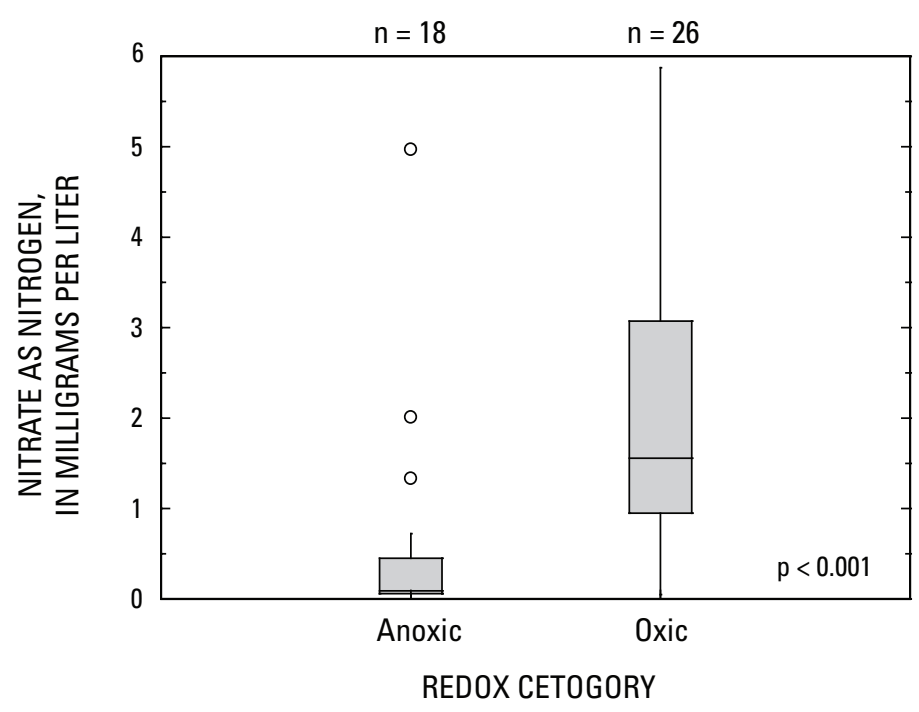

\section{EXPLANATION}

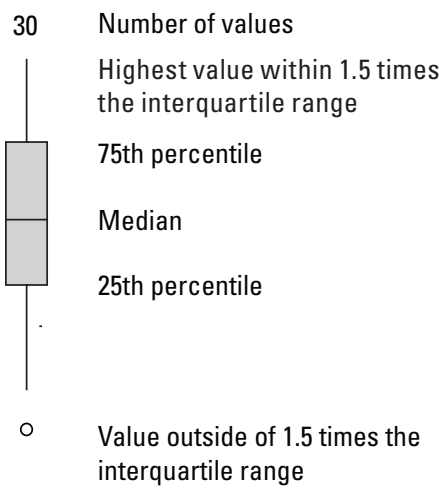

interquartile range

Figure 18. Nitrate plus nitrite concentrations grouped by geochemical (redox) conditions, Northern San Joaquin Basin Groundwater Ambient Monitoring and Assessment (GAMA) study unit. The U.S. Environmental Protection Agency Maximum Contaminant Level for nitrate plus nitrite is 10 milligrams per liter. 
Nitrate has been extensively studied in groundwater in the eastern San Joaquin Valley (for example, Dubrovsky and others, 1998; Burow and others, 2007). Results of previous investigations of nitrate in the Central Valley have shown positive correlations between nitrate concentrations in relatively shallow parts of the aquifer and percentage of agricultural land use (Burow and others, 1998a, 1998b, 2007). The results of this study do not show an inverse relation between nitrate and depth but do show a relation to a specific type of agricultural land use (percentage of orchard and vineyard land use); however, it is unclear if this is an artifact of well selection or a difference in the amount of nitrate applied to this specific land-use type. The lack of a relation between nitrate concentrations and shallow groundwater may result from the fact that in this study, the relation between well depth and nitrate was tested using only grid wells perforated at depths where young recharge affected by agricultural land use can be mixed with deep, older water unaffected by recent land-use practices. This mixing with deeper water may be diluting the nitrate contributed to groundwater at shallow depths. The relation of nitrate to normalized lateral position and redox is due to the fact that nitrate is a redox-sensitive constituent that is removed from groundwater in a reducing environment. Reducing conditions exist more often toward the center of the basin, at the low end of normalized lateral position values.

\section{Trace Elements and Major and Minor lons}

Concentrations of some inorganic constituents can affect aesthetic properties of water, such as taste, color, and odor, and technical properties, such as scaling and staining. Although there are no adverse health effects associated with these properties, they may reduce consumer satisfaction with the water or have economic impacts. For some constituents, CDPH has established non-enforceable benchmarks (SMCL-CAs) that are based on aesthetic or technical properties rather than on health-based concerns. For TDS and the major ions chloride and sulfate, CDPH defines a "recommended" and an "upper" SMCL-CA. In this report, the "upper" SMCL-CA benchmarks were used to compute relative-concentrations; a relative-concentration of 0.5 thus corresponds to a concentration equal to the "recommended" SMCL-CA for these constituents. In all these cases, the "upper" SMCL-CA is twice the "recommended" SMCL-CA. The minor elements manganese and iron also have SMCL-CA benchmarks and had maximum relative-concentrations greater than 0.5 (fig. 15).

Manganese relative-concentrations were high in 34 percent and moderate in 5.4 percent of the primary aquifer (table 9). Wells with moderate or high relative-concentrations of manganese primarily were located in the central and western parts of the study unit (fig. 16D). Iron relative-concentrations were high in 11 percent of the primary aquifer (table 9). The distributions of wells with high and moderate relative-concentrations of manganese and iron were very similar (figs. $16 D$ and $\underline{16 E}$ ).

Chloride, sulfate, and TDS relative-concentrations were high in 3.9, 2.0, and 5.8 percent of the primary aquifer, respectively (table 9). Chloride, sulfate, and TDS relativeconcentrations were moderate in $3.9,3.9$, and 16 percent of the primary aquifer, respectively (table 9). Samples with high and moderate relative-concentrations of TDS were collected from wells primarily located in the Eastern San Joaquin and Tracy study areas (figs.15 and $\underline{16 F}$ ). The dominant anion in most groundwater in the study unit was bicarbonate (appendix D), thus high and moderate relativeconcentrations of TDS need not necessarily be accompanied by high or moderate relative-concentrations of chloride or sulfate given the abundance of bicarbonate. Of the samples with high TDS, chloride and (or) sulfate were high in 33 percent and moderate in 53 percent of the samples. Of the samples with moderate TDS, chloride and sulfate relativeconcentrations were moderate in 10 percent of the samples Sulfate relative-concentrations were high and moderate only in the Tracy study area; chloride relative-concentrations were high and moderate in the Eastern San Joaquin and Tracy study areas.

\section{Factors Affecting Manganese and Iron}

Manganese and iron concentrations were correlated with redox conditions, with higher concentrations of each in anoxic conditions than in oxic conditions (table 6, fig. 19). Like nitrate, manganese and iron are redox sensitive constituents. When concentrations of manganese or iron were compared to classifications of groundwater age or depths to top-ofperforation, neither was shown to be significantly different in terms of age or depth (table 6). Manganese and iron were not correlated to any of the explanatory factors (table 11).

Because manganese and iron are redox-sensitive constituents, geochemical conditions appear to be the primary control affecting manganese and iron concentrations in the Northern San Joaquin Basin study unit. Generally, oxic conditions can result in the precipitation of manganese as a mineral coating, or encrustation, on aquifer sediments. Conversely, under anoxic conditions, these mineral coatings tend to dissolve, releasing manganese back into the water (Stollenwerk, 2003). Similar reactions also are exhibited by arsenic and iron, which tend to co-precipitate with manganese under oxic conditions. As a result, there is a strong positive correlation $(p<0.05)$ between concentrations of arsenic and manganese and between iron and manganese as determined using the Spearman's rank correlation test $(r h o=0.476$ and $r h o=0.618$, respectively). Manganese concentrations (as well as all other major ions and TDS) were highest in the Tracy study area (fig.15), which contains a large part of the Sacramento-San Joaquin Delta, where much of the groundwater is anoxic (fig. 12). 


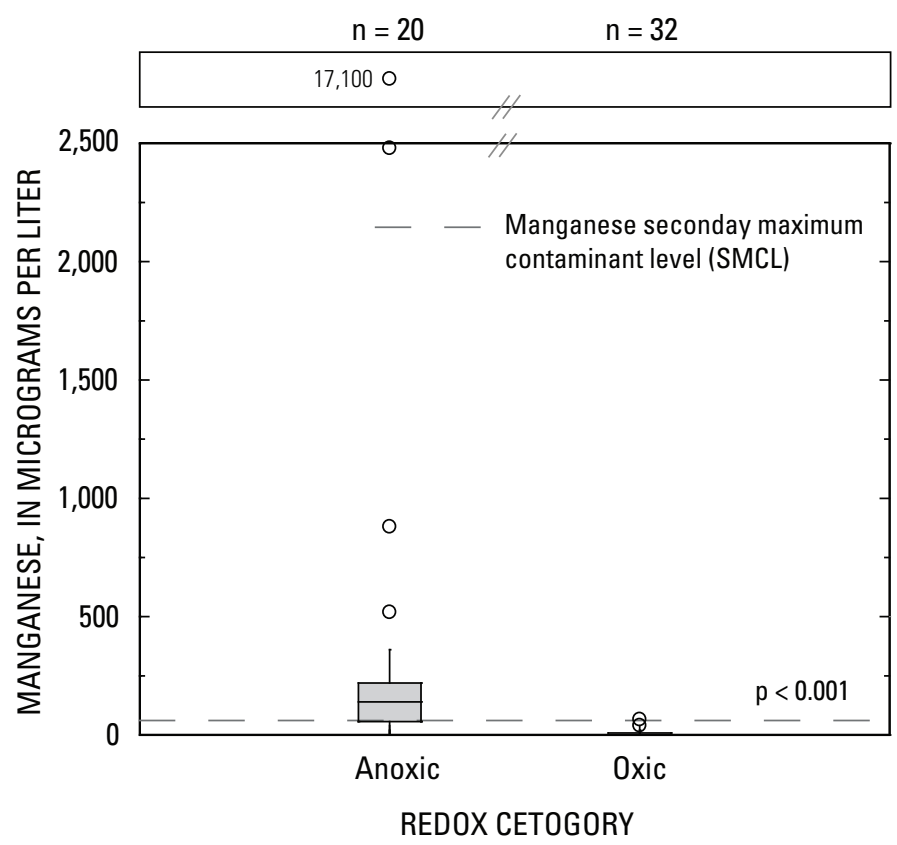

\section{EXPLANATION}

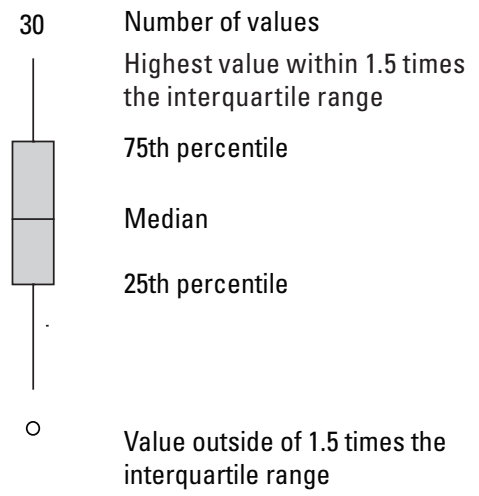

Figure 19. Manganese concentrations grouped by geochemical (redox) conditions, Northern San Joaquin Basin Groundwater Ambient Monitoring and Assessment (GAMA) study unit.

\section{Factors Affecting Total Dissolved Solids}

TDS was significantly positively correlated with $\mathrm{pH}$ and significantly negatively correlated with normalized lateral position from the valley trough (table 11). Within the three study areas east of the San Joaquin River (Cosumnes, Eastern San Joaquin, and the Uplands), concentrations of TDS increase from east to west across the study unit (figs. 16F and 20A). This increase had been noted previously (Bertoldi and others, 1991) and is ascribed to a combination of low-TDS water derived from Sierra Nevada recharge and the effect of regional flow toward the center of the valley. TDS concentrations generally increase with residence time and distance from point of infiltration by interaction between the groundwater and the aquifer sediments. This pattern explains the significant correlation between TDS and normalized lateral position in the study areas east of the San Joaquin River (p<0.001) (fig. 20A).
Concentrations of TDS for wells in the Tracy study area are significantly elevated relative to concentrations for wells in the other study areas and also are correlated with normalized lateral position; however, concentrations of TDS increase toward the valley margin rather than toward the valley trough (fig. 20B). Sources of TDS in the Tracy study area primarily are associated with the proximity of the study area to the Sacramento-San Joaquin Delta, and regional groundwater-flow patterns of the San Joaquin Valley. Historically, the Sacramento-San Joaquin Delta was periodically inundated by saline water, which saturated delta deposits and increased TDS concentrations (Piper and others, 1939). Additionally, the Coast Ranges are composed of easily weathered marine deposits, which results in an elevated TDS in recharge water on the western side of the valley. 


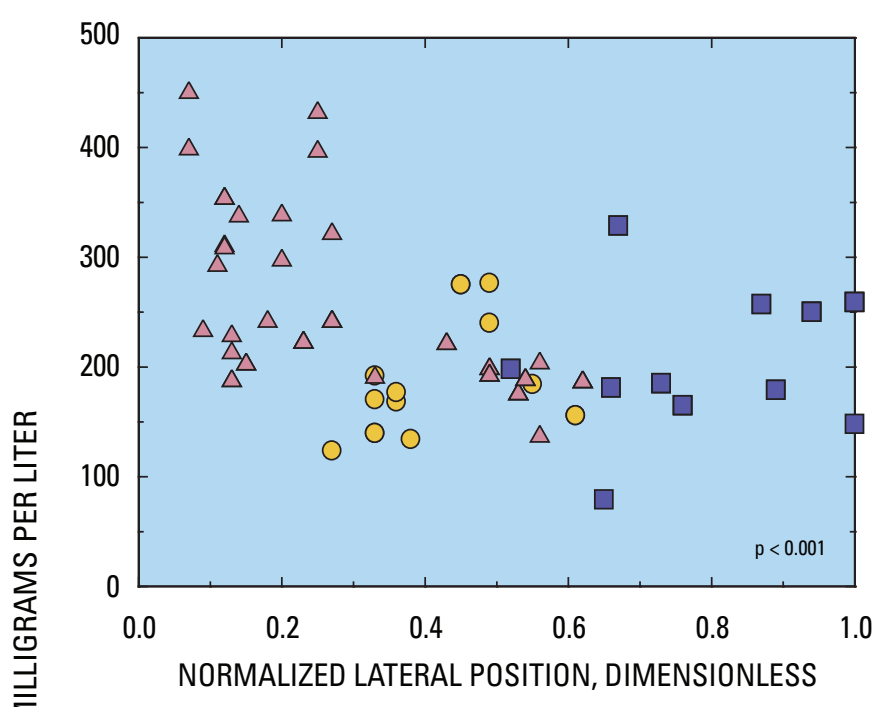

A. Cosumnes, Eastern San Joaquin, and Uplands study areas

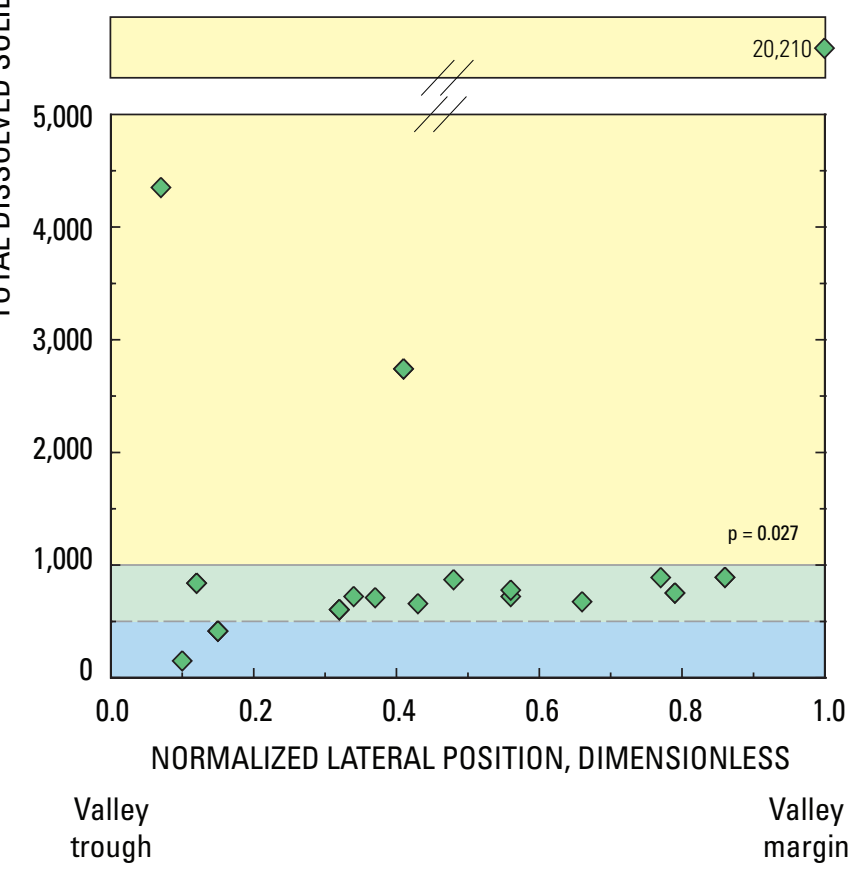

B. Tracy study area

\section{EXPLANATION}

Relative-Concentration

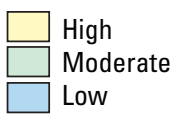

Study Areas

O Cosumnes

$\triangle$ Eastern San Joaquin

$\square$ Uplands

$\diamond$ Tracy
Figure 20. Relation of total dissolved solids concentrations to normalized lateral position within the Cosumnes, Eastern San Joaquin, Upland, and Tracy study areas, Northern San Joaquin Basin Groundwater Ambient Monitoring and Assessment (GAMA) study unit.

\section{Organic Constituents}

The organic compounds are organized by constituent class, specifically, four classes of VOCs and one class consisting of pesticides. VOCs may be present in paints, solvents, fuels, refrigerants, can be by-products of water disinfection, and are characterized by their tendency to evaporate. In this report, VOCs are classified as trihalomethanes, solvents, other VOCs (such as gasoline additives), or fumigants. Pesticides, which include herbicides and insecticides, are used to control weeds, insects, or fungi in agricultural, urban, and suburban settings.

Maximum relative-concentration, and the detection frequency at any concentration, were used as selection criteria for organic and special-interest constituents (fig. 21). Figure 21 shows organic and specialinterest constituents; the $y$-axis indicates maximum relative-concentrations on a log scale.

Maximum relative-concentrations were greater than 0.1 or detection frequency was greater than 10 percent for five organic constituents that were sampled for in all grid wells (fig. 21). Detection frequencies and relativeconcentrations by study area for all grid wells with detections of any VOC (fig. 22) and pesticides (fig. 23) meeting the selection criteria indicate that nearly all detections are at low relative-concentrations and that individual constituent detection frequencies generally were less than 20 percent.

Concentrations of all organic constituents detected, with the exception of DBCP, in USGS-grid wells from the Northern San Joaquin Basin study unit were less than health-based benchmarks. One or more VOCs were detected in about 45 percent of the 51 USGS-grid wells sampled.

Of the 63 pesticides and pesticide degradates sampled at all grid wells, 10 were detected. Of these 10, 6 were parent pesticide compounds with benchmarks, 1 was a parent compound without a benchmark, and 3 were degradates ( 2 of which were degradates of parent compounds with benchmarks) not having a benchmark. The constituents that were not detected and the wells sampled for additional pesticides and pesticide degradates are listed in Bennett and others (2006).

For all organic constituents combined, relative-concentration of at least one organic constituent (table 10) was 2.7 percent of the primary aquifer.

This proportion is based exclusively on high relativeconcentrations of the fumigant DBCP (2.7 percent). The proportion of the primary aquifer with moderate relativeconcentrations of organic constituents was 6.9 percent. 


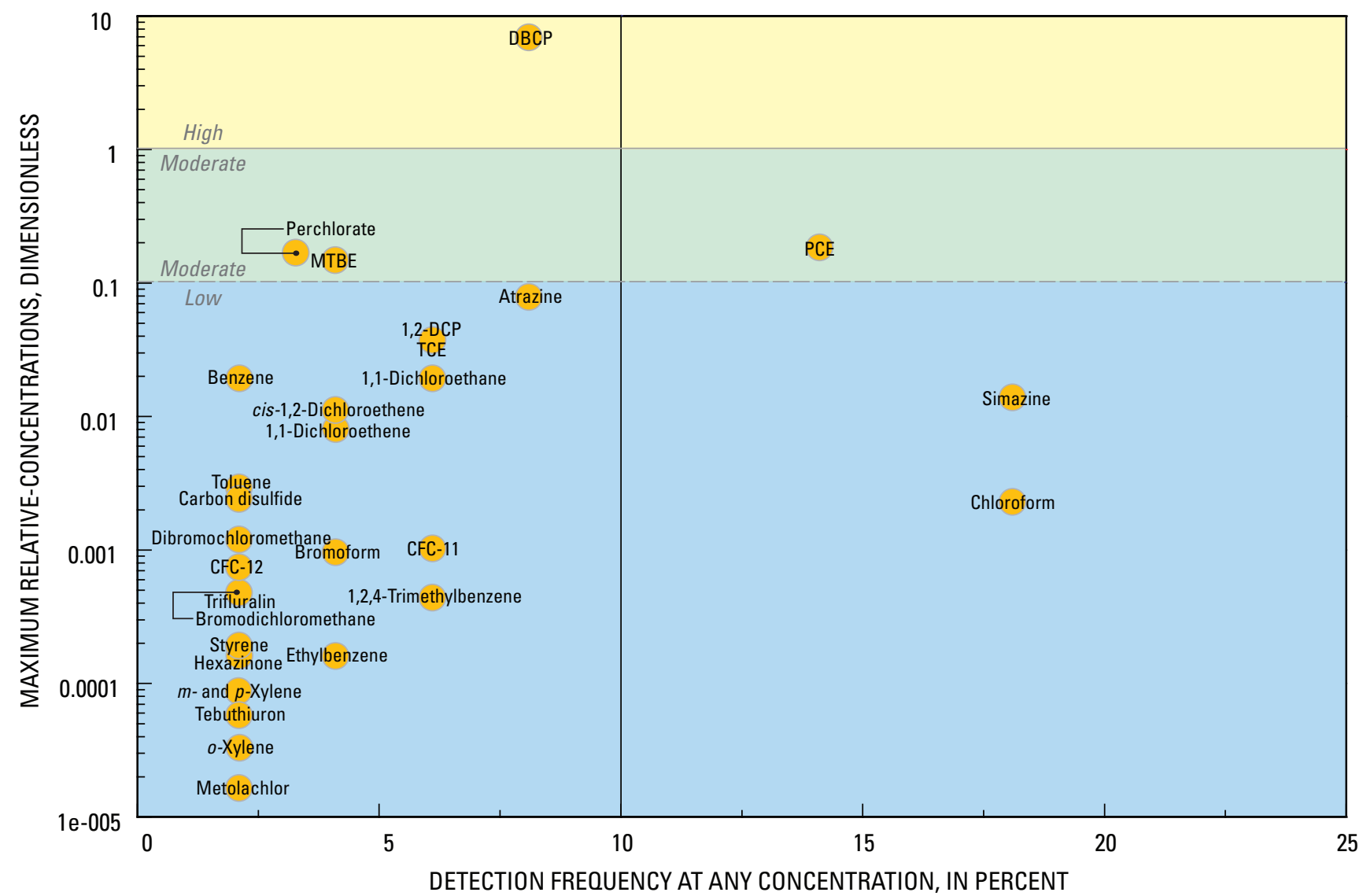

EXPLANATION

\section{Relative-Concentration Abbreviations}

High

Moderate

Low
TCE, trichloroethene; PCE, tetrachloroethene; DBCP, 1,2-dibromo-3-chloropropane 1,2-DCP, 1,2-dichloropropane; CFC-11, trichlorofluoromethane; CFC-12, dichlorodifluoromethane; MTBE, methyl tert-butyl ether.

Figure 21. Detection frequency and maximum relative-concentration for organic and special-interest constituents detected in grid wells, Northern San Joaquin Basin Groundwater Ambient Monitoring and Assessment (GAMA) study unit.

Although most relative-concentrations of organic constituents were low or moderate, detection of these constituents can serve as an indication of groundwater affected by young recharge and recent land-use activities.
Their relation to potential explanatory factors might assist in identifying factors affecting those constituents with high relative-concentrations. 


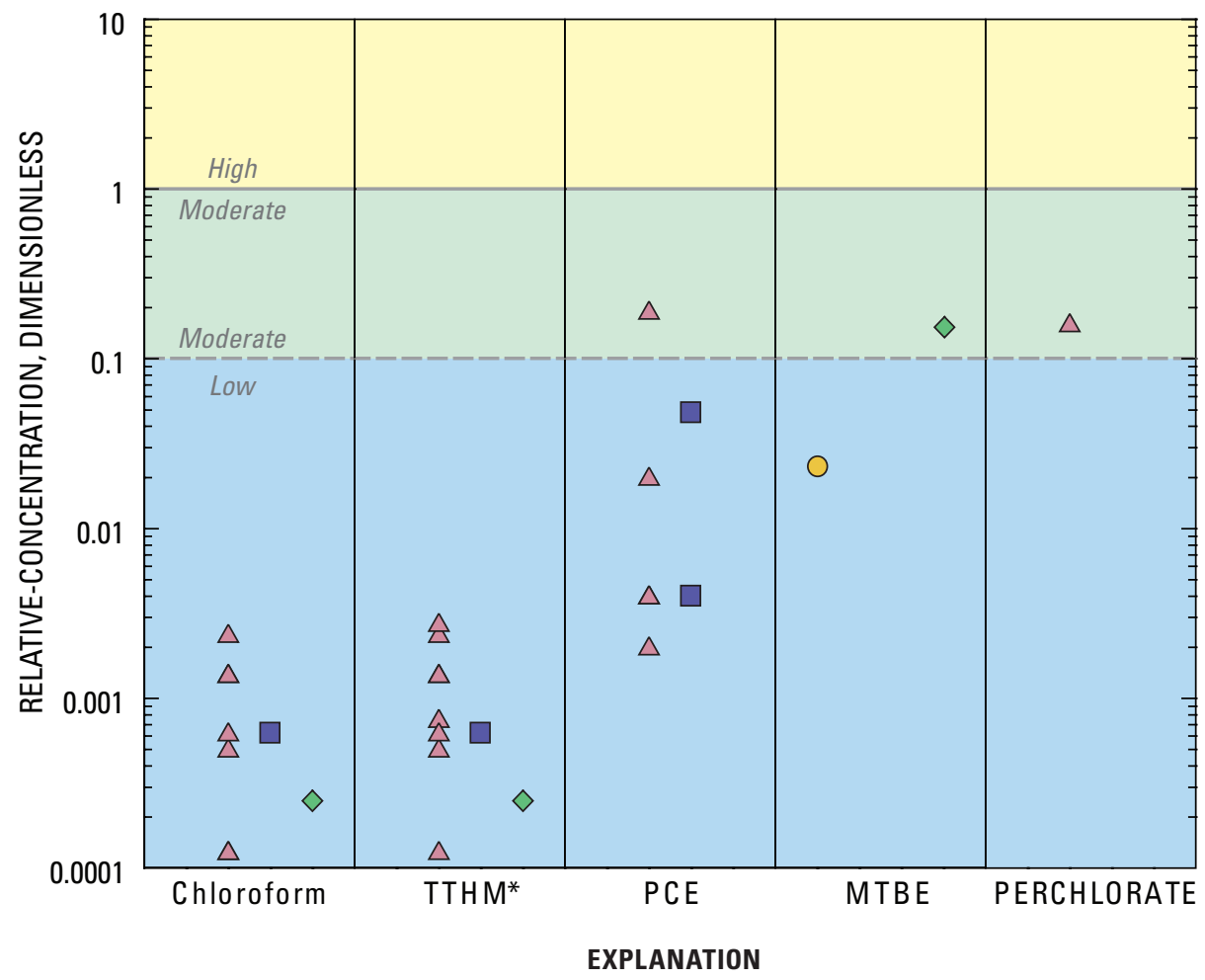

Relative-Concentration

Study Areas

\begin{tabular}{ll}
$\square$ & High \\
\hline$\square$ & Moderate \\
\hline$\square$ & Low
\end{tabular}

O Cosumnes

$\triangle$ Eastern San Joaquin

$\square$ Uplands

$\diamond$ Tracy

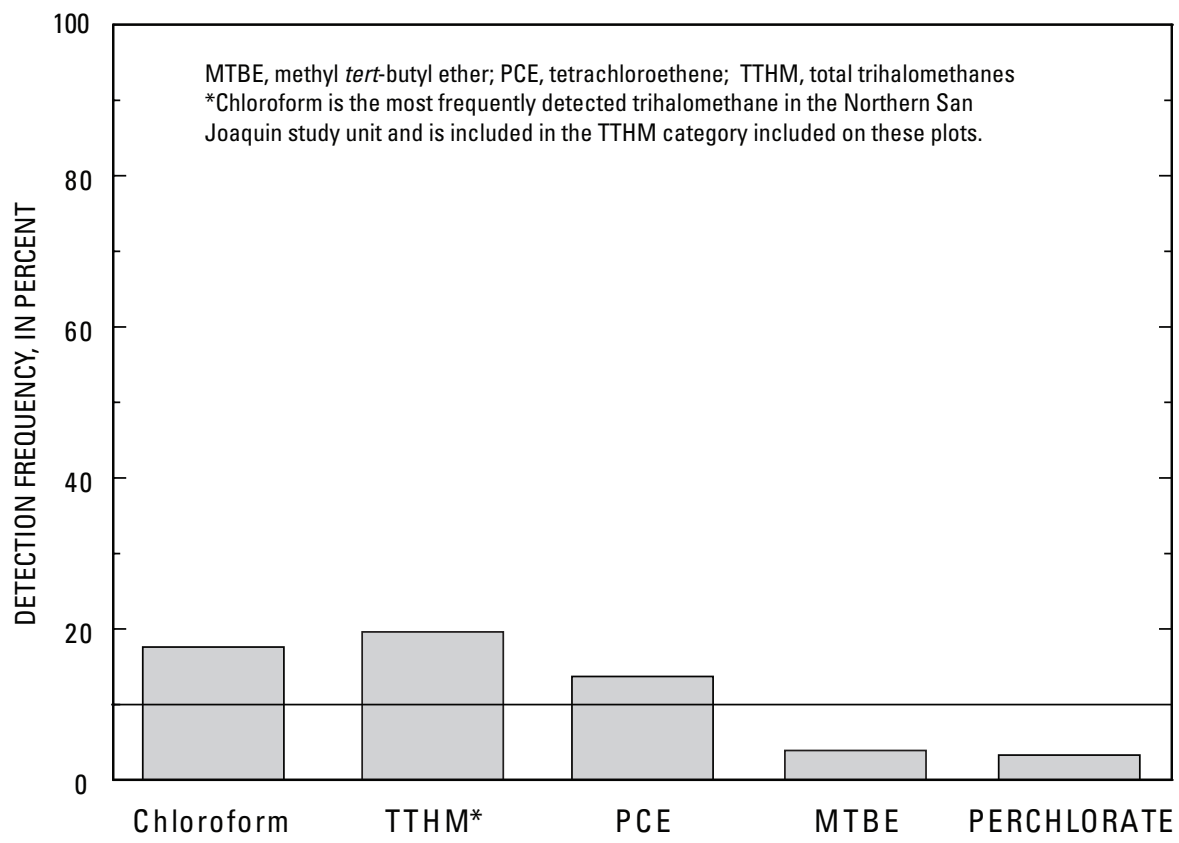

Figure 22. Relative-concentrations and detection frequencies of selected VOC and special-interest constituents in grid wells, Northern San Joaquin Basin Groundwater Ambient Monitoring and Assessment (GAMA) study unit. 

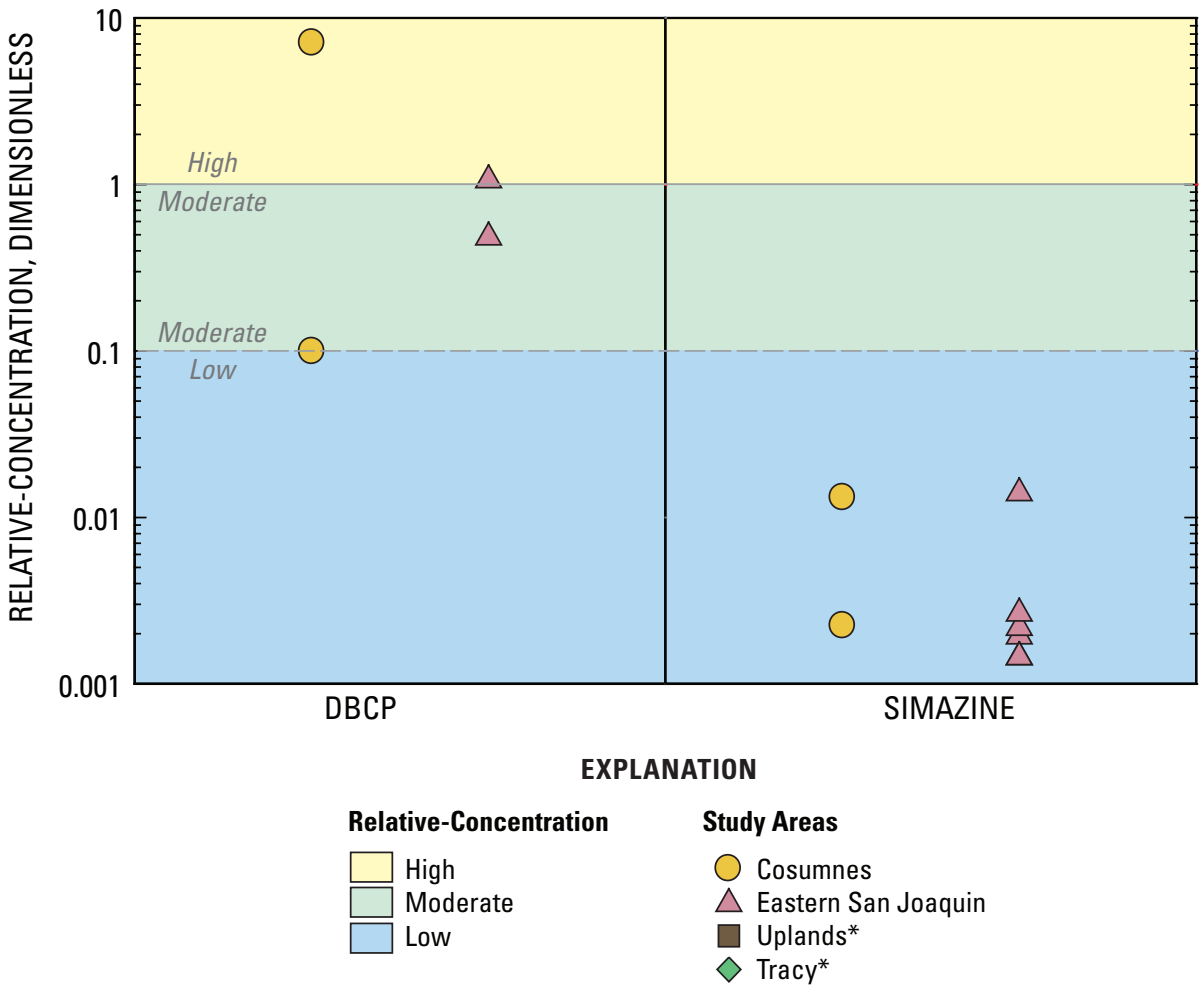

* Study area did not have a detection of DBCP or simazine

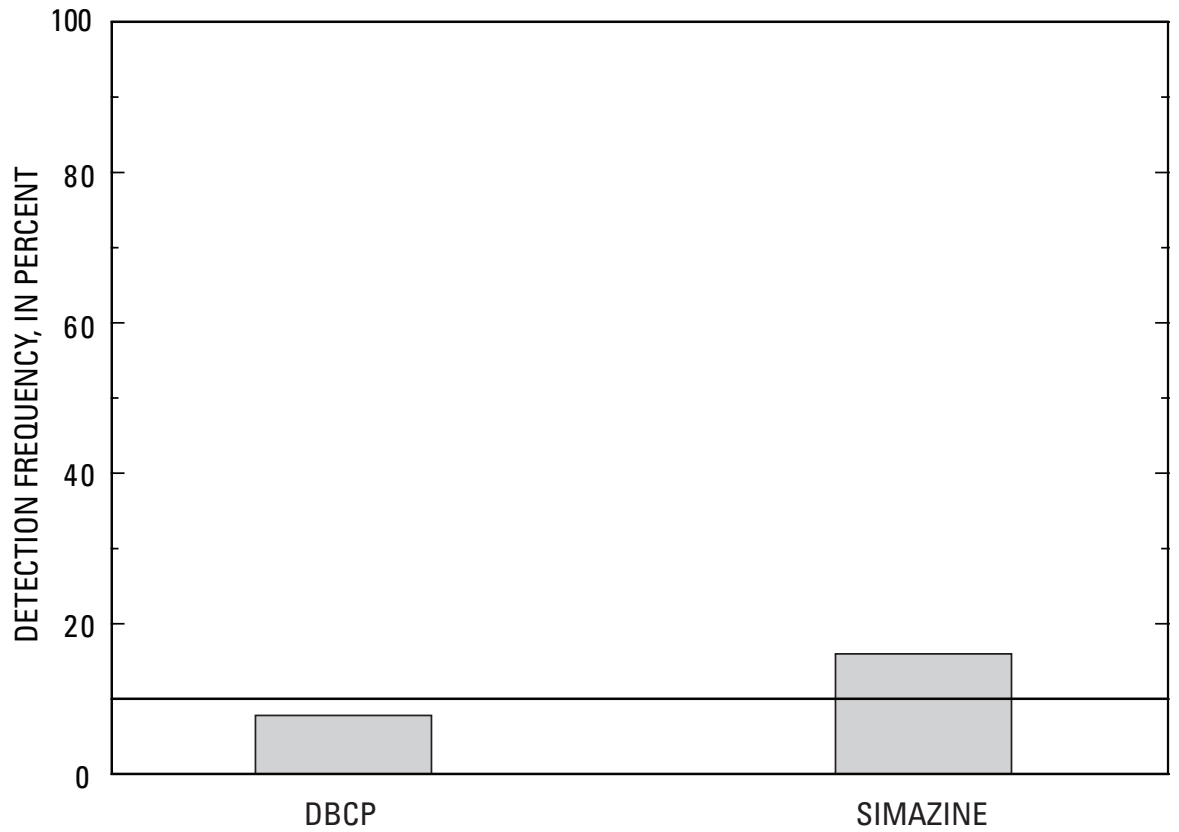

Figure 23. Relative-concentrations and detection frequencies of selected fumigant and pesticide constituents in grid wells, Northern San Joaquin Basin Groundwater Ambient Monitoring and Assessment (GAMA) study unit. 


\section{Trihalomethanes}

An MCL-US has been established for total trihalomethanes (TTHM), which applies to the sum of the four trihalomethane (THM) compounds - chloroform, bromodichloromethane, dibromochloromethane, and bromoform. Chloroform, however, was the only THM detected in more than 10 percent of the wells sampled, and was detected in 9 of the 51 grid wells. The other three THM compounds were detected in one of those nine wells (an Eastern San Joaquin grid well), and bromoform was detected in the absence of the other THMs in another Eastern San Joaquin grid well (Bennett and others, 2006). Total THM (TTHM) concentration, however, rather than the concentration of chloroform alone, was used in the statistical tests for the understanding assessment. Non-detections of TTHMs were set to zero for the summation of TTHM concentrations. TTHMs were detected in 20 percent of the primary aquifer (fig. 22); there were no high or moderate relative-concentrations. TTHMs were more prevalent in the Eastern San Joaquin study area [detection frequency 42 percent ( 8 of 19 wells)] than in the other study areas (detection frequencies $\leq 10$ percent) (fig. 24A; Bennett and others, 2006). Chloroform was the VOC most frequently detected (just greater than 20 percent) in U.S. aquifers sampled for national assessments by the USGS National Water Quality Assessment (NAWQA) Program (Zogorski and others, 2006).

Primary aquifer proportion for TTHMs as a class was equivalent to that of chloroform (tables 9 and 10 ). TTHMs were not detected in high relative-concentrations in wells from the CDPH database based on the most recent $\mathrm{CDPH}$ data (January 1, 2001-April 21, 2004).

\section{Factors Affecting Trihalomethanes}

TTHM concentrations were significantly correlated with groundwater age, land use, normalized lateral position, and well depth (tables 6 and 11). TTHM concentrations in wells with groundwater classified as young age based on tritium concentrations were significantly higher and frequency of detection was greater than those wells with groundwater classified as old (table 6, fig. 25). TTHM concentrations were positively correlated with well depth $(r h o=0.263)$ and amount of urban land use ( $r h o=0.601)$ (table 11), and negatively correlated with the amount of agricultural and natural land use. Nationally, TTHM concentrations have been reported to be correlated with percentage of urban land use (Zogorski and others, 2006). Potential urban sources of TTHMs include recharge from landscape irrigation with disinfected water, leakage from distribution or sewer systems, and industrial and commercial sources (Ivahnenko and Barbash, 2004). The negative correlation between TTHMs and normalized lateral position likely is a spurious correlation resulting from the negative correlation between urban land use and normalized lateral position (table 6). The most urbanized area in the study unit, the city of Stockton, is located on the east bank of the San Joaquin River in the center of the valley (fig. 6). Of the 15 wells with detections of TTH-Ms, depths to topof-perforation were less than $200 \mathrm{ft}$ for 11 of the 15 wells (fig. 26). Of the 11 wells with detections of TTHM with depths to top-of-perforation less than $200 \mathrm{ft}, 7$ wells (64 percent) were surrounded by greater than 60 percent urban land use.

\section{Solvents}

Chlorinated solvents have various industrial, commercial, and domestic uses, including as drain and pipe cleaners, dry cleaning fluids, oven cleaners, shoe polish, household degreasers, deodorizers, leather dyes, photographic supplies, tar remover, waxes, and pesticides (Zogorski and others, 2006). Although chloroform can be used as a solvent, it was not counted in this class because it was already considered as a TTHM. Because many of the factors associated with the occurrences of individual chlorinated solvents were similar in the national NAWQA groundwater studies (Zogorski and others, 2006), solvents were considered as a class rather than as individual constituents for the understanding assessment presented here. Total solvent concentration was defined as the sum of the concentrations of all detected chlorinated solvents, with nondetections assumed to have a concentration of zero. As a class, concentrations of solvents were high in 0.1 percent and moderate in 1.8 percent of the primary aquifer (table 10). Grid cells were assigned a high or moderate classification based on individual constituents within the class with high or moderate relative-concentrations. PCE was the primary constituent accounting for the high and moderate relativeconcentrations of solvents (table 9). Most of the other solvents detected in the grid wells or reported in the CDPH database were compounds that can be degradation products of PCE [trichloroethene (TCE), dichloroethene (DCE), and vinyl chloride).

PCE was detected in 13 percent of the primary aquifer, and all but one of the detections were at low relativeconcentrations (fig. 22). As with THMs, the detection frequency of PCE was highest in the Eastern San Joaquin study area (26 percent; fig. 24B; Bennett and others, 2006). The detection frequency in the Upland study area was 18 percent and PCE was not detected in the Cosumnes and Tracy study areas (fig. 24B ). All wells with detections of PCE or other solvents reported in the CDPH database were in the Eastern San Joaquin study area (fig. 24B). Nationally, PCE was the solvent most frequently detected in aquifers, on the basis of assessments by the USGS NAWQA Program (Zogorski and others, 2006). 


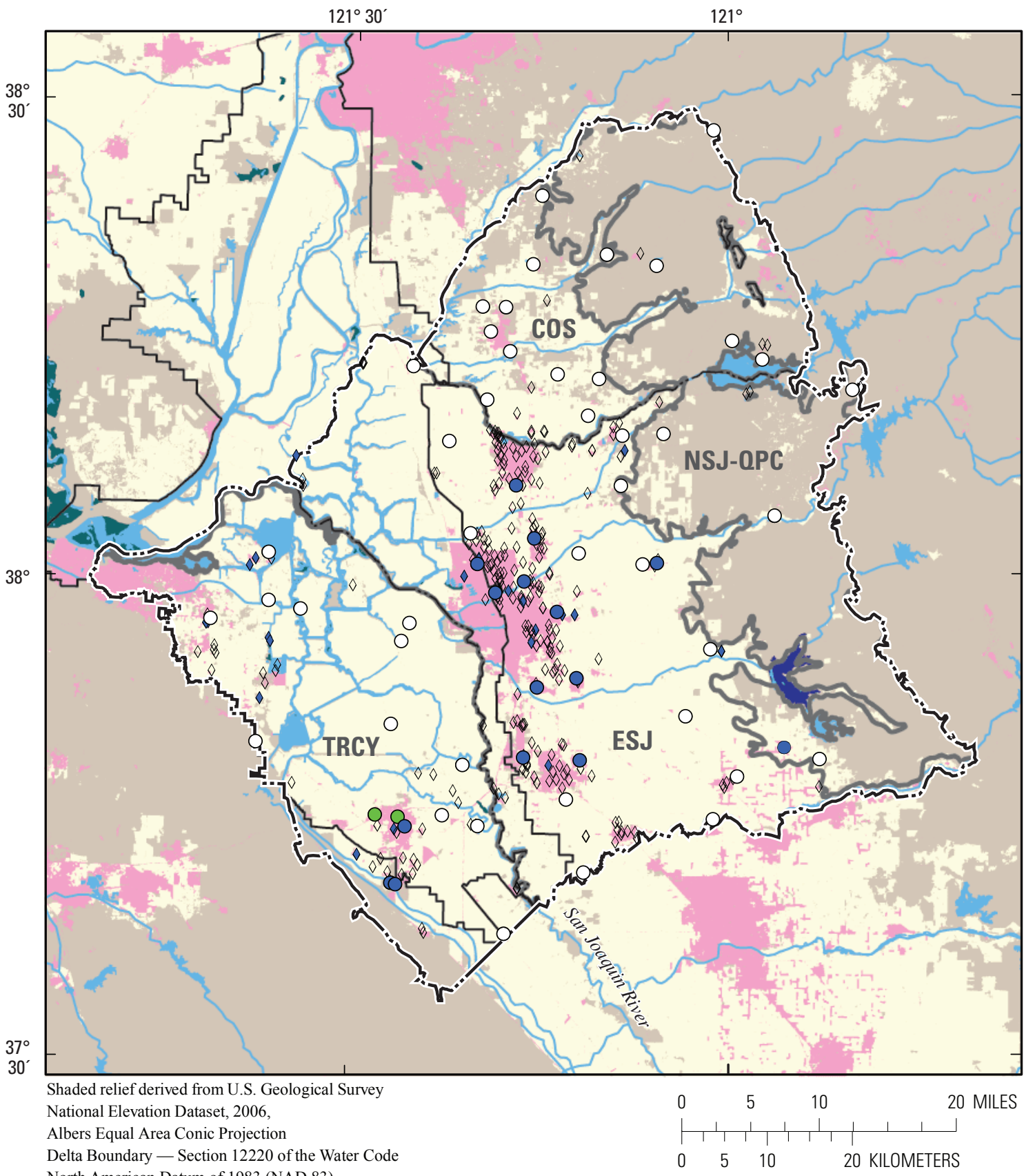

\section{A. Sum of total trihalomethanes (TTHMs)}

\section{Land use}

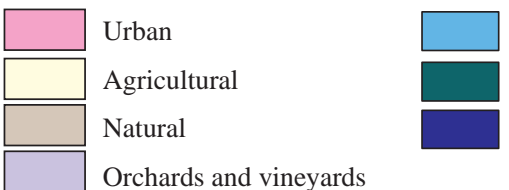

Water bodies

Swamp or marsh

Inundation area

\section{EXPLANATION}

B oundary of SacramentoSan J oaquin D elta

B oundary of N orthern San J oaquin Basin

-..- B oundary of subbasin of N orhern San J oaquin B asi

\section{Relative-Concentration}

Grid and Understanding CDPH Wells Wells

Not detected

O Low

O Moderate

O High

\section{Study areas}

Cosumnes (COS)

Eastern San J oaquin (ESJ)

U plands (NS]-QPC)

Tracy (TRCY)

Figure 24. Relative-concentrations of selected organic constituents for USGS-grid and USGS-understanding wells representative of the primary aquifer and from the most recent analysis (January 1, 2001-April 21, 2004) for CDPH wells, Northern San Joaquin Groundwater Ambient Monitoring and Assessment (GAMA) study unit. 


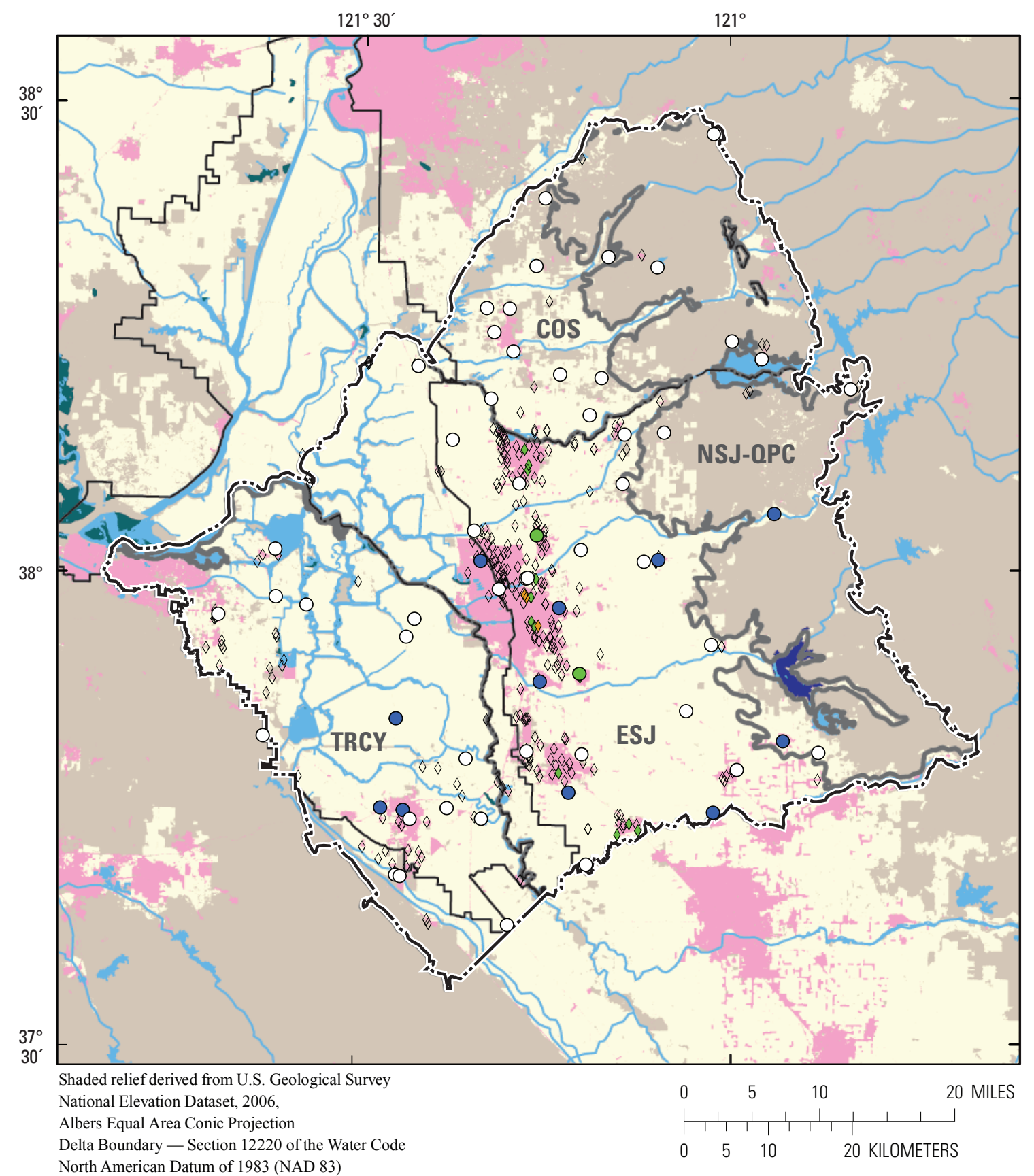

B. Sum of solvents

Figure 24.-Continued 


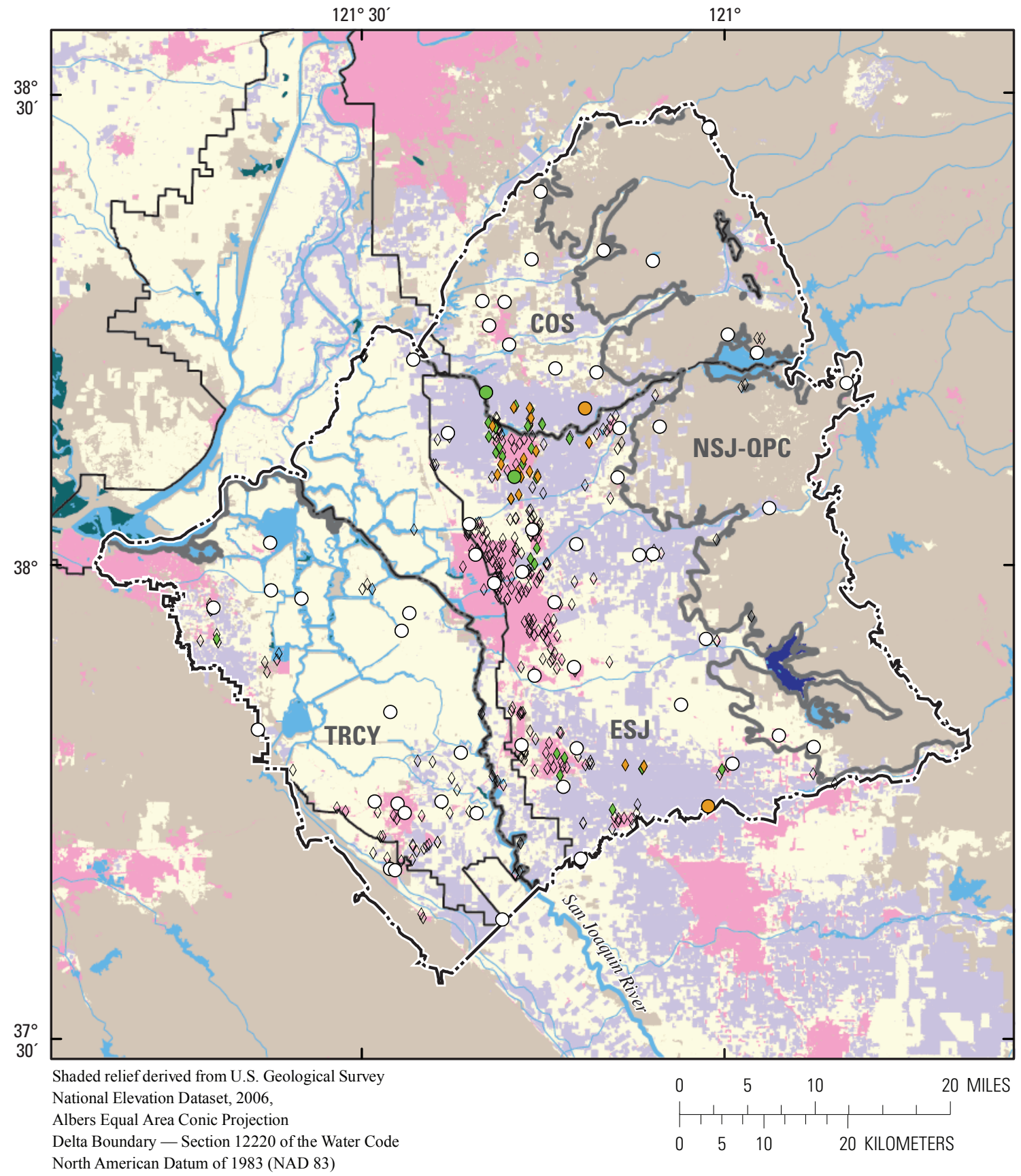

C. $\mathrm{DBCP}$

Figure 24.-Continued 


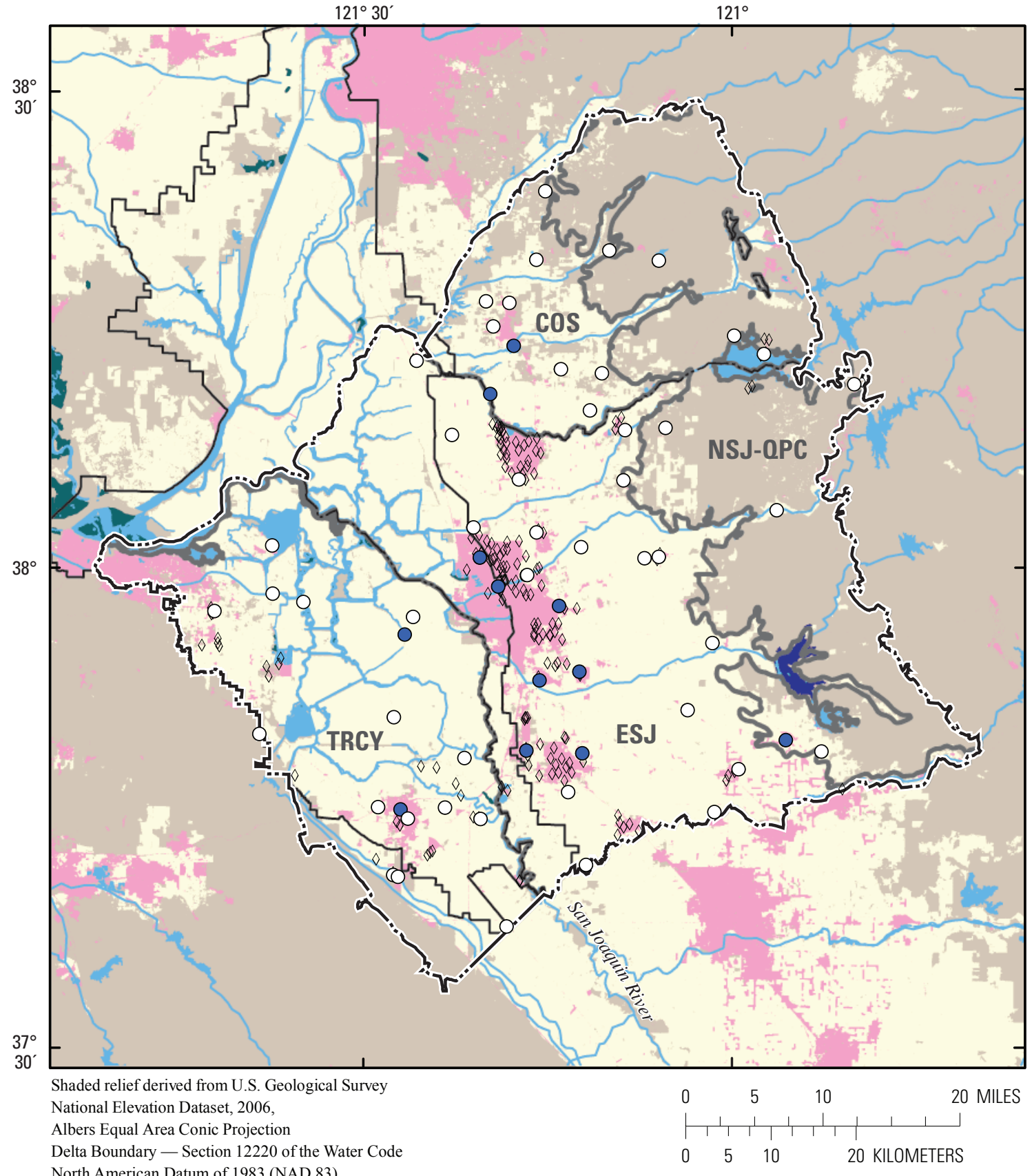

D. Sum of pesticides

Figure 24.-Continued 


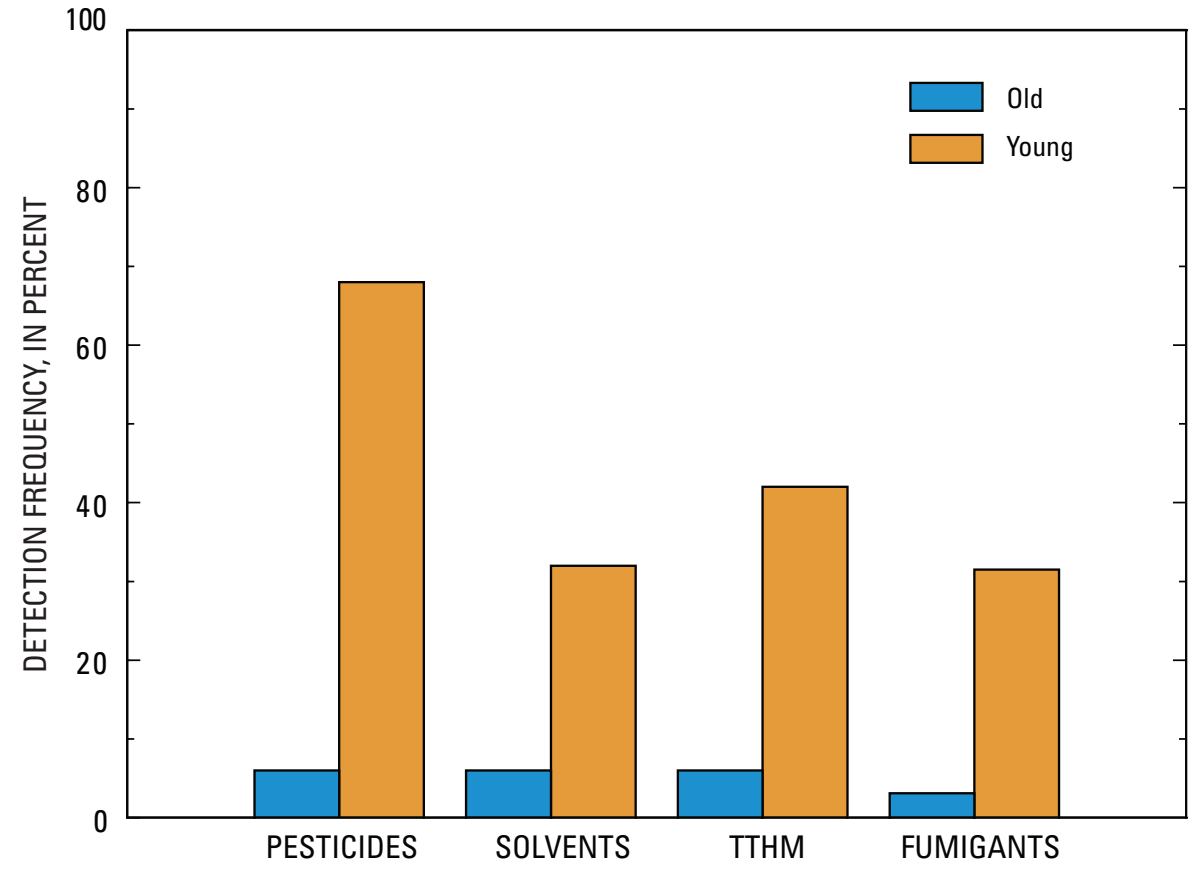

URBAN LAND USE, IN PERCENT

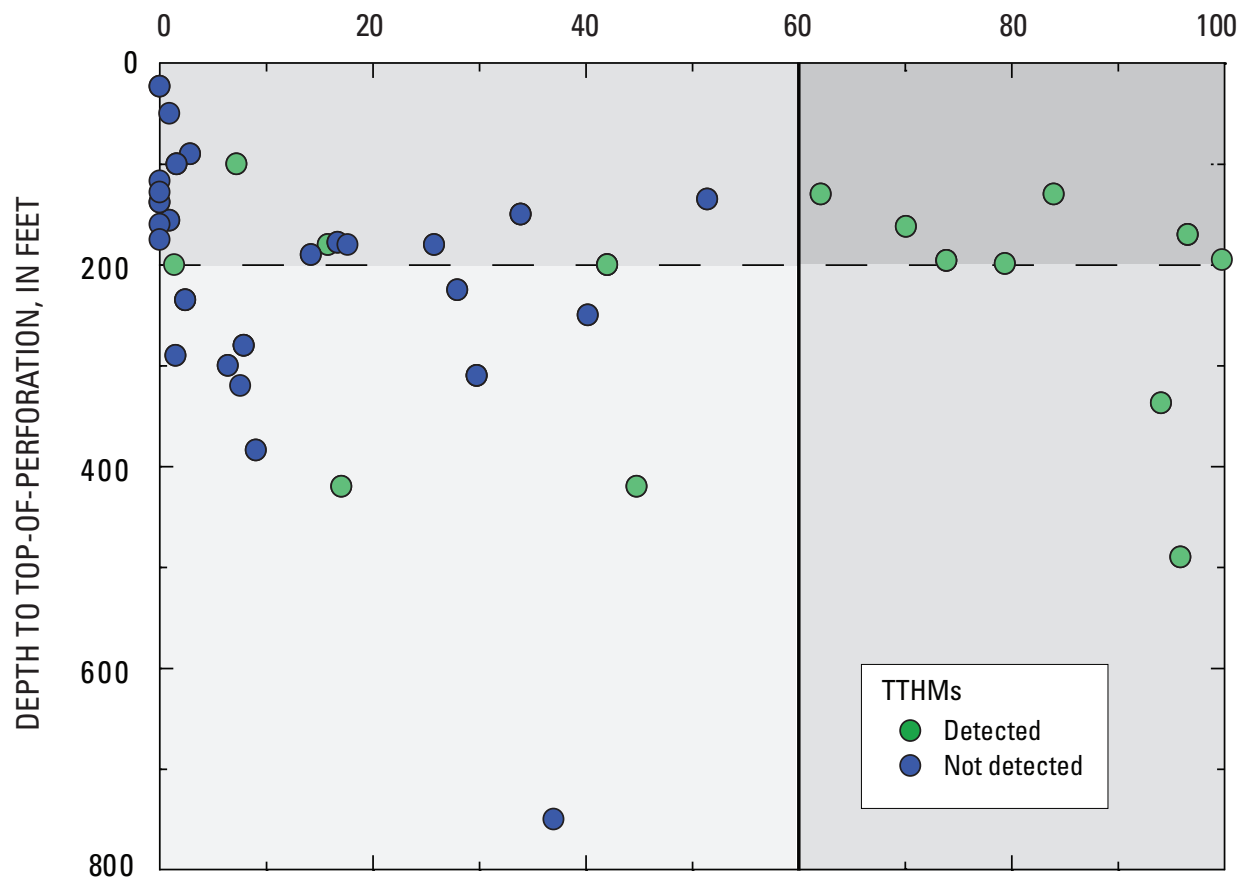

Figure 25. Pesticide, solvent, total trihalomethane (TTHM), and fumigant detection frequencies grouped by groundwater-age classification, Northern San Joaquin Basin Groundwater Ambient Monitoring and Assessment (GAMA) study unit.
Figure 26. Relation between detections of total trihalomethanes (TTHMs) and depth to top-ofperforation and percentage of urban land use in 500-m buffer areas surrounding wells for USGS-grid and USGS-understanding well samples, Northern San Joaquin Basin Groundwater Ambient Monitoring and Assessment (GAMA) study unit. 


\section{Factors Affecting Solvents}

Solvent concentrations in groundwater samples classified as young were significantly higher than concentrations in groundwater samples classified as old, and the frequency of solvent detections was greater in samples classified as young than those classified as old (table 6, fig. 25). Solvent concentrations were positively correlated with urban land use and negatively correlated with agricultural land use (table 11, fig. 24B). Although solvent concentrations were not significantly correlated with either well depth or depth to top-of-perforation, of the eight wells with detections only one had a depth to the top-of-perforations of greater than $200 \mathrm{ft}$. (fig. 27). Six of the remaining seven wells with solvent detections were surrounded by greater than 60 percent urban land use. These correlations suggest that occurrences of solvents and THMs in the primary aquifer of the Northern San Joaquin Basin study unit are related to the presence of young groundwater recharging beneath urban areas, and that this young groundwater has infiltrated to depths of as much as $200 \mathrm{ft}$ below land surface.

\section{Other VOCs}

VOCs that can not be classified as a THM, solvent, or fumigant in this study were placed in the "other VOC" class. Only one constituent was placed in this class, methyl tert-butyl ether (MTBE), a gasoline oxygenate used to raise the octane number and promote more complete fuel combustion. MTBE was detected at moderate relative-concentrations in 2.1 percent of the primary aquifer (table 9). In a national assessment of VOCs in groundwater in the U.S., MTBE was the second most frequently detected VOC (at a $0.2 \mu \mathrm{g} / \mathrm{L}$ assessment level) in samples from domestic and drinking-water wells (Zogorski and others, 2006). Because MTBE was not detected at high relative-concentrations or in greater than 10 percent of the wells sampled, no statistical tests were done in relation to the explanatory factors discussed in this report.

\section{Fumigants}

Fumigants are gaseous forms of pesticides applied to soils, grain, produce, and structures for the purpose of pest control. As a form of pesticide, fumigants are grouped with pesticides on some graphs presented in this report. Those VOCs primarily are used as fumigants to control pests in agriculture and in households and synthesis by-products included in fumigant mixtures were grouped into their own constituent class for the purpose of this report (fumigants). The classification of these constituents as fumigants was initially determined by the USGS National Water Quality Assessment Program (Zogorski and others, 2006).

One fumigant, DBCP, was detected at high relative-concentrations in the primary aquifer (figs. 21 and 23). DBCP relative-concentrations were high in 2.7 percent of the primary aquifer; the highest proportion of any organic constituent (table 9). DBCP relative-concentrations were high and moderate only in the Cosumnes and Eastern San

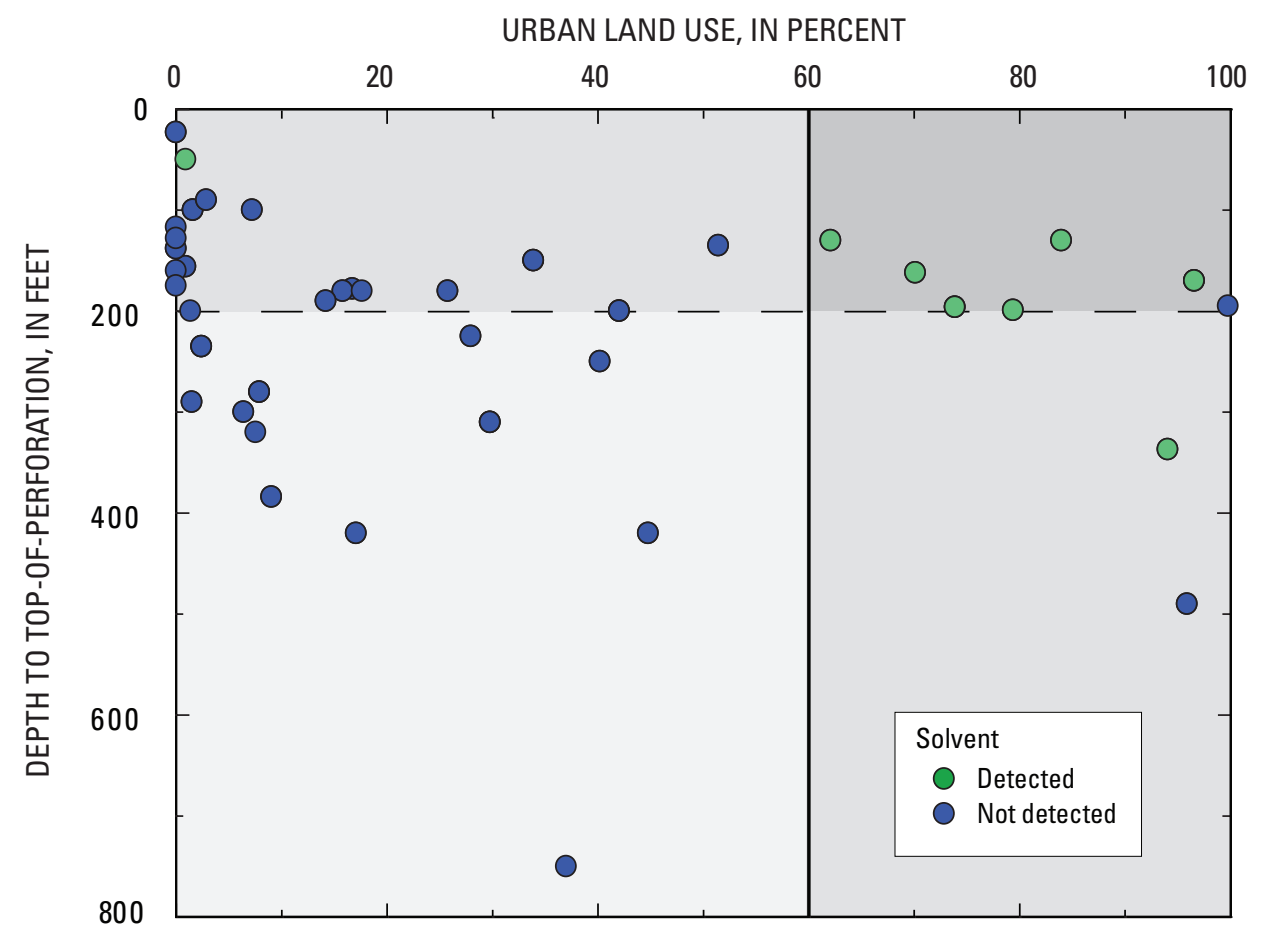

Figure 27. Relation between detections of solvents and depth to top-of-perforation and percentage of urban land use in 500 -m buffer areas surrounding wells for USGS-grid and USGS-understanding well samples, Northern San Joaquin Basin Groundwater Ambient Monitoring and Assessment (GAMA) study unit. 
Joaquin study areas (fig. 24C). DBCP was the only fumigant detected in grid wells; therefore, the fumigant class in this study is equivalent to relative-concentrations and detections of DBCP. DBCP was used as a soil fumigant to control nematodes, primarily on orchards and vineyards but also on some row crops, between about 1955 and 1977 in California (Peoples and others, 1980; Domagalski, 1997). Use of DBCP was discontinued by the California Department of Food and Agriculture in 1977 because of its detection in groundwater and its toxicity (U.S. Environmental Protection Agency, 2000). Additional fumigants-1,2-dibromoethane, 1,2-dichloropropane (1,2-DCP), and 1,4-dichlorobenzenewere detected using the spatially weighted approach but were not detected using the grid-based approach. Relativeconcentrations of 1,2-dibromoethanwere high in less than 0.1 percent of the primary aquifer; and relative-concentrations of 1,2-dichloropropane (1,2-DCP) and 1,4-dichlorobenzene were moderate in 0.1 and 0.6 percent of the primary aquifer, respectively (table 9). One fumigant, 1,2-dibromoethane (EDB), was detected at a high concentration in one of the understanding wells and thus is not represented in the grid-based assessment.

\section{Factors Affecting Fumigants}

Fumigant concentrations (equivalent to concentrations of DBCP) were (1) significantly negatively correlated with depths to top-of-perforation (table 11), (2) significantly lower in those water samples categorized as old as compared to those categorized as young (table 6), and (3) significantly positively correlated with percentage of orchard/vineyard land use (table 11). The fumigant DBCP was the most frequently detected fumigant or pesticide in groundwater samples collected from the San Joaquin Valley during 1971-88 (Domagalski, 1997) and in California as a whole up to 1999 (Troiano and others, 2001). Detection frequencies of DBCP in groundwater in the Central Valley have been higher than in most other parts of the country because of historical use of this compound as an agricultural fumigant on orchards and vineyards (Dubrovsky and others, 1998; Zogorski and others, 2006). As with solvents and TTHMs, fumigants in this study were most frequently detected in younger groundwater (fig. 25). Fumigants were detected at depths to top-of-perforation of $200 \mathrm{ft}$ or less (fig. 28). DBCPs physical and chemical properties (low vapor pressure and moderate solubility) contribute to its ability to be transported into the aquifer (Burlinson and others, 1982). Ideal conditions for DBCP transport into groundwater exist in the eastern San Joaquin Valley. Tests on DBCPs ability to be retained or sorbed to aquifer sediments or biologically transformed indicate that in conditions with relatively low organic content in soils, DBCP is only weakly sorbed, and in well-oxygenated groundwater, $\mathrm{DBCP}$ is resistant to biological transformation (Bloom and Alexander, 1990; Deeley and others, 1991; Burow and others, 1999). Organic content in aquifer materials in the eastern study areas (Cosumnes, East San Joaquin, and Upland) are minor in comparison to the Sacramento-San Joaquin Delta and redox conditions in these study areas are predominantly oxic (fig. 12).

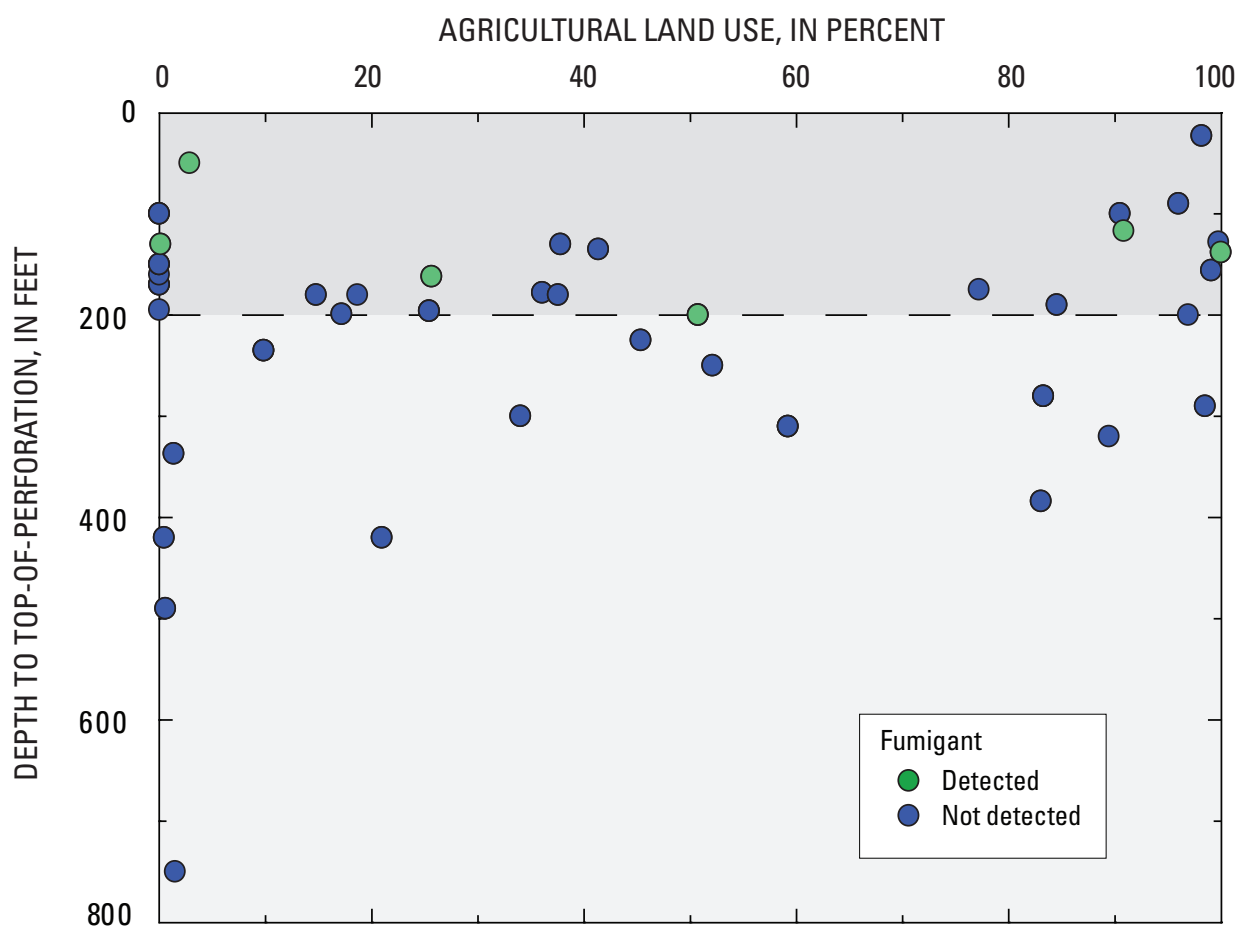

Figure 28. Relation between detections of fumigants and depth to top-of-perforation and percentage of agricultural land use in 500-meter buffer areas surrounding wells for USGS-grid and USGS-understanding well samples, Northern San Joaquin Basin Groundwater Ambient Monitoring and Assessment (GAMA) study unit. 


\section{Pesticides}

All detections of pesticides in samples from the Northern San Joaquin Basin study unit were at low relative-concentrations (igss. 14, $\underline{21}$, and $\underline{23}$ ). At least one pesticide was detected in water from 22 percent of grid wells sampled (11 of 50). The maximum relative-concentration $(0.08)$ for any pesticide was for atrazine, and the only pesticide detected in more than 10 percent of the grid wells was simazine. The study-unit detection frequency for simazine was 16 percent, but the detections were not evenly distributed geographically; the detection frequencies in the four study areas were 32 percent in East San Joaquin, 20 percent in Cosumnes, and 0 percent in Tracy and Upland.

Simazine is most commonly applied to vineyards and orchards in the study unit, but it also is used on roadways for weed control (Domagalski and Dubrovsky, 1991). Simazine was the triazine pesticide most frequently detected in groundwater collected in a study by the California Department of Pesticide Regulation summarizing the presence of pesticides in California as of December 1999 (693 of 10,403 wells) (Troiano and others, 2001) and in 183 wells in the San Joaquin Valley in 1985-87 (Domagalski and Dubrovsky, 1991). Simazine also was among the most frequently detected pesticides or pesticide degradates in groundwater in major aquifers across the United States (Gilliom and others, 2006).

Detections of individual pesticides were grouped together and are discussed here as a class of pesticide constituents. Pesticides were not detected at moderate or high relativeconcentrations in the grid wells (table 10). Similarly, there were no current high relative-concentrations of pesticides in the CDPH database. For the understanding assessment, pesticide concentrations were summed with nondetections treated as zeros. In addition to simazine, five other pesticides with health-based benchmarks, and three degradates of pesticides with health-based benchmarks were detected in grid wells - atrazine, deethylatrazine (a degradate of atrazine), 3,4-dichloroanaline (a degradate of diuron), 2,6-diethylaniline (a degradate of alachlor), hexazinone, metolachlor, tebuthiuron, and trifluralin. All detections were at low relativeconcentrations, and only deethylatrazine was detected in more than 10 percent of the grid wells (Bennett and others, 2006). The concentrations of these nine pesticides were summed and this summation was used for the statistical tests on the pesticide class. The distribution of pesticide detections was similar to that of simazine detections; most of the detections were in the Eastern San Joaquin study area (fig. 24D).

\section{Factors Affecting Pesticides}

Pesticide concentrations were significantly related to groundwater age, depth to top-of-perforation, and normalized lateral position (tables 6 and 11). Groundwater classified as young had a significantly higher detection frequency of pesticides as a class (fig. 25) and contained significantly higher pesticide concentrations than groundwater classified as old (fig. 25, table 6). With the exception of one understanding well screened at $337 \mathrm{ft}$ below land surface, all pesticides were detected in wells with a depth to top-of-perforation of less than $200 \mathrm{ft}$ (fig. 29; table 11). As with the solvents, TTHMs, and fumigants, the correlation with age and depth suggests that pesticides in the primary aquifer of the Northern San Joaquin Basin study unit are related to young groundwater and that this young groundwater has infiltrated to depths of as much as $200 \mathrm{ft}$ below land surface (fig. 29). Pesticide concentrations were negatively correlated to normalized lateral position, indicating increasing pesticide concentration with decreasing distance to the center of the basin. Most pesticides were detected in wells along the western side of the East San Joaquin study area (fig. 24D; table 11). Pesticide concentrations were not correlated with any of the land-use categories. This might be because simazine and some of the other pesticides detected have both agricultural and non-agricultural uses (Gilliom and others, 2006). Pesticides commonly are used on rights-of-way and in landscaping, and thus may be associated with urban land use.

\section{Special-Interest Constituents}

Special-interest constituents measured in the Northern San Joaquin Basin study unit were N-nitrosodimethylamine (NDMA), 1,2,3-trichloropropane (1,2,3-TCP), and perchlorate. These constituents were selected for analysis because they have been detected recently in, or are considered to have the potential to reach, water resources used for drinking-water supply (California Department of Public Health, 2009a, 2009b, 2010). NDMA was found in California drinking-water wells in 1998, and is a by-product of rocket fuel production and is used in a number of industrial processes. Additionally, it has been shown to be a by-product of drinking-water disinfection. Small concentrations of NDMA have been shown to be harmful to humans; therefore. it has an established benchmark notification level of $10 \mathrm{ng} / \mathrm{L}$, which is equal to $0.010 \mu \mathrm{g} / \mathrm{L}$ (California Department of Public Health, 2009a). In 2001, California required the monitoring of 1,2,3-TCP in groundwater to gather information about its presence in drinking-water sources. 1,2,3-TCP has a number of uses, including as a paint remover, cleaning agent, solvent, chemical intermediate, and pesticide (California Department of Public Health, 2009b). Perchlorate became a regulated constituent in drinking water in California in October 2007. Perchlorate has been shown to interfere with the thyroid gland, which can affect pre- and post-natal development and mental development in adults (California Department of Public Health, 2010). Perchlorate is most commonly associated with the production of rockets, missiles, and fireworks, but it also has natural sources, including fertilizer from Chile (Urbansky and others, 2001; Dasgupta and others, 2006). 


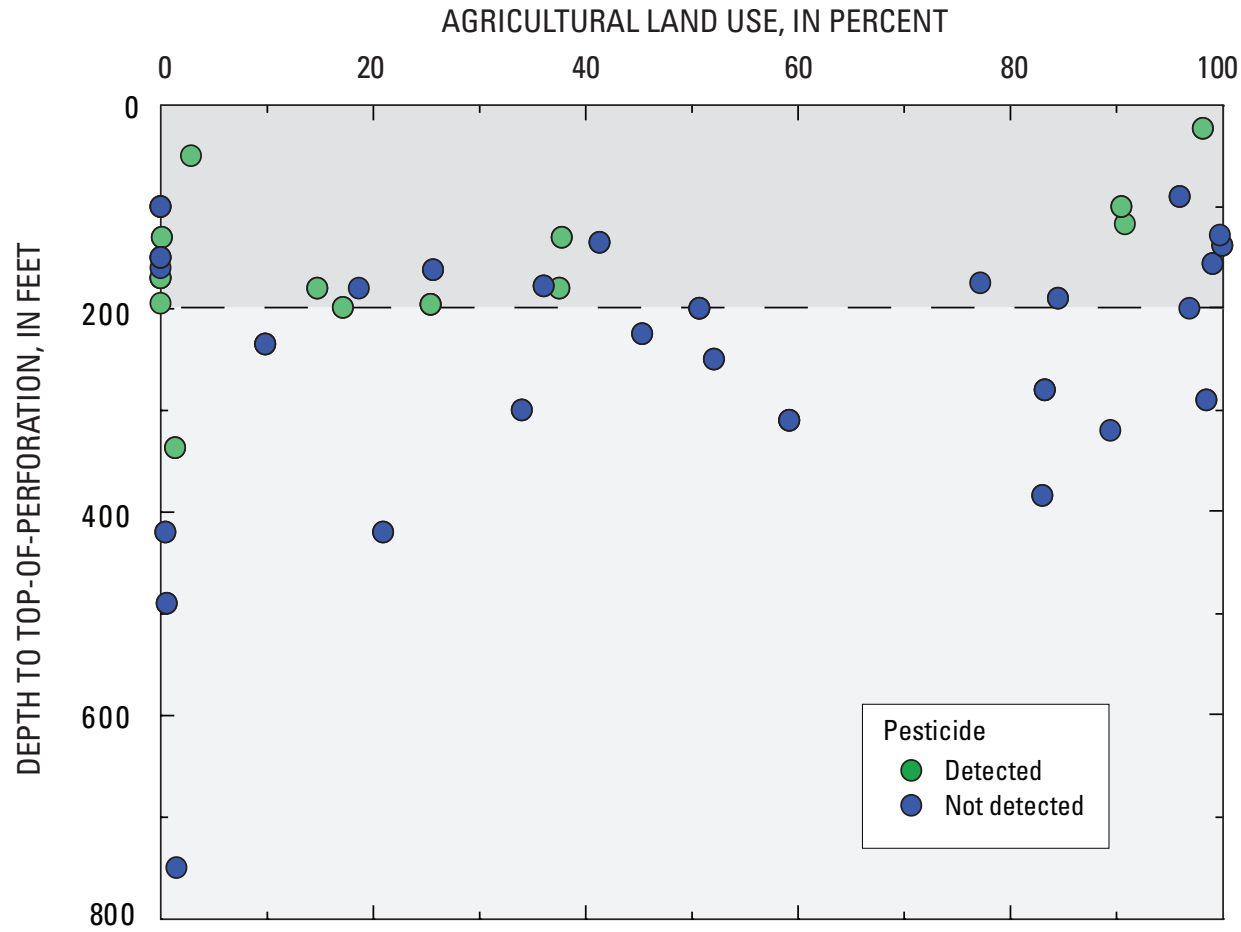

Figure 29. Relation between detection of pesticides and depth to top-of-perforation and percentage of agricultural land use in 500-m buffer areas surrounding wells for USGS-grid and USGS-understanding well samples, Northern San Joaquin Basin Groundwater Ambient Monitoring and Assessment (GAMA) study unit.
NDMA and 1,2,3-TCP were not detected in any of the 21 grid wells sampled. Perchlorate was detected in one well in the Northern San Joaquin Basin study unit at a concentration of $1 \mu \mathrm{g} / \mathrm{L}$ (Bennett and others, 2006).Perchlorate was detected in the Eastern San Joaquin study area and the relativeconcentration was 0.16 (fig. 22). Perchlorate was detected at a high concentration in water from a well in the current CDPH database. The perchlorate detection in this well was a high relative-concentration within the prior period (January 1, 2001-April 21, 2004); however, the most recent (post-priorperiod) sample from that well was a nondetection (table 9). Because perchlorate was not detected at a high concentration or in greater than 10 percent of the sampled wells, no statistical analysis was done.

\section{Summary}

Groundwater quality in the 2,079-square mile Northern San Joaquin Basin (Northern San Joaquin) study unit was investigated as part of the Priority Basin Project of the Groundwater Ambient Monitoring and Assessment (GAMA) Program. Samples were collected during January 2004 through February 2005 from 61 wells.

The USGS-GAMA Priority Basin Project was designed to provide a statistically robust characterization of the quality of untreated (raw) groundwater in the Northern San Joaquin Basin study unit. Fifty-one grid wells were randomly selected by the USGS within spatially distributed grid cells, with no more than one well per cell. Samples were collected from these USGS-grid wells and from 10 additional wells for analysis of 175 to 306 constituents. Additional data were selected from the CDPH database for the most recent 3-year period available at the time of analysis (January 1, 2001April 21, 2004) to supplement data for USGS-grid wells, as inorganic constituents were not measured by the USGS in some grid cells (CDPH-grid wells). Raw detection frequencies were calculated using all available CDPH and GAMA data; these frequencies are provided for comparison, but potentially are spatially biased because the wells are not uniformly distributed geographically. Unbiased, grid-based and spatially weighted approaches were used to determine aquifer-scale proportions of constituents measured at high, moderate, and low relative-concentrations in the primary aquifer.

Relative-concentrations were used as the primary metric for comparing concentrations of constituents. Constituents with high or moderate relative-concentrations or with detection frequencies greater than 10 percent were selected to focus the understanding assessment on those constituents that have the greatest effect on water quality. The relativeconcentration threshold for classifying a constituent as moderate was 0.5 for inorganic constituents and 0.1 for organic constituents. The lower threshold value for organic constituents was selected because these constituents are anthropogenic in origin, generally less prevalent, and have lower relative-concentrations than naturally occurring inorganic constituents. 
Of the inorganic constituents with a health-based benchmark, relative-concentrations of at least one constituent were high for 13 percent, moderate for 29 percent, and low for 58 percent of the primary aquifer. High relative-concentrations of inorganic constituents with health-based benchmarks primarily resulted from high relative-concentrations of trace elements (13 percent of the primary aquifer), and to a lesser extent from high relative-concentrations of radioactive constituents (2.1 percent of the primary aquifer) and nutrients (2.1 percent of the primary aquifer). Inorganic constituents with high relative-concentrations for the grid wells were arsenic ( 9.4 percent of the primary aquifer) and boron (7.6 percent of the primary aquifer). Inorganic constituents with moderate relative-concentrations for the grid wells were arsenic (19 percent of the primary aquifer), barium (2.1 percent of the primary aquifer), boron ( 9.4 percent of the primary aquifer), nitrate (9.0 percent of the primary aquifer), strontium (6.4 percent of the primary aquifer), and vanadium (16 percent of the primary aquifer). Spatially weighted aquifer-scale proportions of constituents with high relativeconcentrations always fell within the 90-percent confidence intervals of the grid-based aquifer-scale proportions for constituents with high relative-concentrations, indicating that the grid-based approach yielded results that were statistically equivalent to those obtained using the spatially weighted approach and incorporating CDPH data.

Of the inorganic constituents with a non-healthbased benchmark, relative-concentrations of at least one constituent were high for 36 percent of the primary aquifer, moderate for 31 percent, and low for 33 percent. High relative-concentrations of inorganic constituents with non-health-based benchmarks primarily resulted from high relative-concentrations of manganese (34 percent of the primary aquifer), and to a lesser extent iron (11 percent of the primary aquifer), TDS (5.8 percent of the primary aquifer), chloride ( 3.9 percent of the primary aquifer), and sulfate (2.0 percent of the primary aquifer). Twenty-two of the 75 measured VOCs (not including fumigants) in grid wells were detected. All VOCs detected in grid-well samples from the Northern San Joaquin Basin study unit were at concentrations less than health-based benchmarks. The maximum relative-concentrations of 20 of 22 (91 percent) detected VOCs were low. The detected VOCs at moderate relative-concentrations in grid wells were MTBE and PCE. When data from the most recent analysis in the CDPH database during the current period were included in the analysis, relative-concentrations of two VOCs - PCE and vinyl chloride - were high in small proportions of the primary aquifer ( 0.1 percent each). Detection frequencies were less than 10 percent for 20 of 22 VOCs ( 91 percent). Chloroform and PCE were the two VOCs with detection frequencies greater than 10 percent in the grid wells.
Relative-concentrations for the soil fumigant DBCP were high in 2.7 percent of the primary aquifer; the highest primary-aquifer proportion of any organic constituent, even though its use was discontinued in California in 1977. DBCP relative-concentrations were moderate in another 2.7 percent of the primary aquifer. DBCP remains one of the most frequently detected fumigants in groundwater due to its use as a soil fumigant on orchards and vineyards throughout the San Joaquin Valley up until the late 1970s, and due to its physical and chemical properties (low vapor pressure and moderate solubility) that contribute to its persistence in groundwater.

Of the 63 pesticide and pesticide degradates analyzed for all grid wells, nine (18 percent) were detected. Of the nine pesticides and pesticide degradates detected, six were parent compounds with benchmarks and three were degradates without a benchmark. Relative-concentrations for all six of the parent compounds with benchmarks were low. Only the pesticide simazine and pesticide degradate deethylatrazine were detected in more than 10 percent of the grid wells.

One special-interest constituent, perchlorate was detected at a moderate relative-concentration in one grid well. Perchlorate was not detected at high relative-concentrations in any wells.

Relations between water quality and five explanatory factors (land use, depth, normalized lateral position, groundwater age, and geochemical conditions) were evaluated statistically. Land use represented by the wells (defined as the percentages of urban, agricultural, and natural land use within a 500-meter buffer surrounding the well) was more urban than was land use for the study unit as a whole, likely a result of the tendency to locate drinking-water wells near population centers. Well depths ranged from 83 to 930 feet with a median depth of 360 feet. Normalized lateral position, a measure of the location of a well with respect to distance from the valley trough and normalized to the distance between the valley margin and the trough, was determined for all wells. Grid wells were distributed across the entire range of normalized lateral positions. Groundwater ages were classified as young or old based on ${ }^{3} \mathrm{H}$ (tritium) concentrations. Thirtysix of 61 wells were classified as young and 25 were classified as old. Redox conditions were assigned based on relativeconcentrations of redox-sensitive constituents for the wells sampled that had redox information; groundwater in the Northern San Joaquin Basin study unit primarily was oxic (33 of 61 wells; 54 percent).

Groundwater age, normalized lateral position, and redox conditions were the most significant explanatory factors related to inorganic constituent concentrations. Groundwater age was shown to be associated with concentrations of arsenic, gross alpha radioactivity, and total dissolved solid (TDS). High and moderate relative-concentrations of arsenic, iron, and manganese primarily were associated with 
geochemical conditions. Arsenic relative-concentrations were high in oxic, high-pH waters and in anoxic waters. High relative-concentrations of iron and manganese were most commonly associated with anoxic waters. Normalized lateral position was shown to be associated with arsenic, nitrate, and TDS concentrations. High and moderate relative-concentrations of arsenic and total dissolved solids were more often closer to the basin center (valley trough), whereas concentrations of nitrate tended to decrease towards the basin center.

Groundwater age, well depth, and land use within 500 meters of each sampled well were the most significant factors affecting organic constituent concentrations. Trihalomethanes, fumigants, pesticides, and solvents were all shown to have higher concentrations in young groundwater than in old groundwater. Fumigant and pesticide concentrations were related to well perforation depth, with shallower perforation depths having higher constituent concentrations. Detections of trihalomethanes and solvents were positively associated with urban land use and negatively associated with agricultural land use. Fumigant detections were strongly correlated with a specific agricultural land use - orchards and vineyards. Young groundwater, shallow well depths, and urban land use are commonly related to the occurrence of organic constituents in the Northern San Joaquin Basin study unit.

\section{Acknowledgments}

The authors thank the following cooperators for their support: the California State Water Resources Control Board, California Department of Public Health, California Department of Water Resources, and Lawrence Livermore National Laboratory. We especially thank the well owners and water purveyors for their generosity in allowing the USGS to collect samples from their wells. Funding for this work was provided by State bonds authorized by Proposition 50 and administered by the SWRCB.

\section{References Cited}

Belitz, Kenneth, Dubrovsky, N.M., Burow, K.R., Jurgens, B.C., and Johnson, T., 2003, Framework for a ground-water quality monitoring and assessment program for California: U.S. Geological Survey Water-Resources Investigations Report 03-4166, 78 p.

Bennett, G.L., V, Belitz, Kenneth, and Milby Dawson, B.J., 2006, California GAMA Program - Ground-water quality data in the northern San Joaquin basin study unit, 2005: U.S. Geological Survey Data Series 196, 122 p. (Also available at: http://pubs.usgs.gov/ds/2006/196/.)
Bertoldi, G.L., Johnston, R.H., and Evenson, K.D., 1991, Ground water in the Central Valley, California - A summary report: U.S. Geological Survey Professional Paper 1401-A, $44 \mathrm{p}$.

Bloom, R.A., and Alexander, Martin, 1990, Microbial transformation of 1,2-dibromo-3-chloropropane (DBCP): Journal of Environmental Quality, v. 19, p. 722-726.

Brown, L.D., Cai, T.T., and DasGupta, Anirban, 2001, Interval estimation for a binomial proportion: Statistical Science, v. 16 , no. 2 , p. 101-117.

Burlinson, N.E., Lee, L.A., and Rosenblatt, D.H., 1982, Kinetics and products of hydrolysis of 1,2-dibromo-3chloropropane: Environmental Science and Technology, v. 16 , no. 9 , p. 627-632.

Burow, K.R., Shelton, J.L., and Dubrovsky, N.M., 1998a, Occurrence of nitrate and pesticides in ground water beneath three agricultural land-use settings in the eastern San Joaquin Valley, California, 1993-1995: U.S. Geological Survey Water-Resources Investigations Report 97-4284, $51 \mathrm{p}$.

Burow, K.R., Stork, S.V., and Dubrovsky, N.M., 1998b, Nitrate and pesticides in ground water in the eastern San Joaquin Valley, California: occurrence and trends: U.S. Geological Survey Water-Resources Investigations Report 98-4040A, 33 p.

Burow, K.R., Panshin, S.Y., Dubrovsky, N.M, Vanbrocklin, David, and Fogg, G.E., 1999, Evaluation of processes affecting 1,2-dibromo-3-chloropropane (DBCP) concentrations in ground water in the Eastern San Joaquin Valley, California: Analysis of chemical data and groundwater flow and transport simulations: U.S. Geological Survey Water-Resources Investigations Report 99-4059, $57 \mathrm{p}$.

Burow, K.R., Shelton, J.L., Hevesi, J.A., and Weissmann, G.S., 2004, Hydrogeologic characterization of the Modesto area, San Joaquin Valley, California: U.S. Geological Survey Scientific Investigations Report 2004-5232, 54 p. (Also available at: http://pubs.usgs.gov/sir/2004/5232/.)

Burow, K.R., Dubrovsky, N.M., and Shelton, J.L., 2007, Temporal trends in concentrations of DBCP and nitrate in ground water in the eastern San Joaquin Valley, California, USA: Hydrogeology Journal, v. 15, no. 5, p. 991-1007.

Burow, K.R., Shelton, J.L., and Dubrovsky, N.M., 2008, Regional nitrate and pesticide trends in ground water in the eastern San Joaquin Valley, California: Journal of Environmental Quality, v. 37, no. 5_Supplement, S-249-S-263. 
California Department of Health Services, 2007, California Code of Regulations. Title 22, Division 4 Environmental Health, Chapter 15 Domestic Water Quality and Monitoring Regulations. Register 2007, No. 4 (current as of January 26, 2007), http://ccr.oal.ca.gov/ (accessed March 3, 2008).

California Department of Public Health, 2010, Perchlorate in drinking water, http://www.cdph.ca.gov/certlic/ drinkingwater/Pages/Perchlorate.aspx (accessed May 27, 2010).

California Department of Public Health, 2009a, NDMA and other nitrosamines-Drinking water issues: $\mathrm{http}$ ://www. cdph.ca.gov/certlic/drinkingwater/Pages/NDMA.aspx (accessed May 27, 2010).

California Department of Public Health, 2009b, 1,2,3-trichloropropane: http://www.cdph.ca.gov/certlic/ drinkingwater/Pages/123TCP.aspx (accessed May 27, 2010).

California Department of Water Resources, 1993, SacramentoSan Joaquin Delta atlas: California Department of Water Resources, $121 \mathrm{p}$.

California Department of Water Resources, 2003, California's groundwater: California Department of Water Resources Bulletin 118, 246 p., http://www.water.ca.gov/groundwater/ bulletin118/update2003.cfm

California Department of Water Resources, 2006a, San Joaquin Valley Groundwater Basin, Eastern San Joaquin Subbasin: California Department of Water Resources Bulletin 18, accessed May 25, 2010, at http:// www.water.ca.gov/pubs/groundwater/bulletin_118/ basindescriptions/5-22.01.pdf

California Department of Water Resources, 2006b, San Joaquin Valley Groundwater Basin, Cosumnes Subbasin: California Department of Water Resources Bulletin 18, accessed May 25, 2010, at http://www.water.ca.gov/pubs/ groundwater/bulletin_118/basindescriptions/5-22.16.pdf

California Department of Water Resources, 2006c, San Joaquin Valley Groundwater Basin, Tracy subbasin: California Department of Water Resources Bulletin 18, accessed May 25, 2010, at http://www.water.ca.gov/pubs/ groundwater/bulletin_118/basindescriptions/5-22.15.pdf

California Office of Administrative Law, 2009, Online source for California Code of Regulations, accessed December 1, 2009, at http://ccr.oal.ca.gov/linkedslice/default. asp? $\mathrm{SP}=\mathrm{CCR}-1000 \&$ Action $=$ Welcome.

California State Water Resources Control Board, 2003, A comprehensive groundwater quality monitoring program for California: Assembly Bill 599 Report to the Governor and Legislature, March 2003, 100 p. http://www.waterboards. ca.gov/gama/docs/final ab 599 rpt to legis 7 31 03.pdf.
Chapelle, F.H., McMahon, P.B., Dubrovsky, N.M., Fuji, R.F., Oaksford, E.T., and Vroblesky, D.A., 1995, Deducing the distribution of terminal electron-accepting processes in hydrologically diverse groundwater systems: Water Resources Research, v. 31, no. 2, p. 359-371.

Chapelle, F.H., 2001, Ground-water microbiology and geochemistry ( $2^{\mathrm{d}}$ ed.): New York, John Wiley and Sons, Inc., $477 \mathrm{p}$.

Clark, I.D., and Fritz, P., 1997, Environmental isotopes in hydrogeology: New York, Lewis Publishers, 328 p.

Craig, H., and Lal, D., 1961, The production rate of natural tritium: Tellus, v. 13, p. 85-105.

Dasgupta, P.K., Dyke, J.V., Kirk, A.B., and Jackson, W.A., 2006, Perchlorate in the United States: analysis of relative source contributions to the food chain: Environmental Science and Technology, v. 40, no. 21, p. 6608-6614.

Davis, S.N., and Hall, F.R., 1959, Water-quality of eastern Stanislaus and northern Merced counties, California: Stanford University Publications, Geological Sciences, v. 6, no. $1,112 \mathrm{p}$.

Davis, G.H., Green, J.H., Olmsted, F.H., and Brown, D.W., 1959, Groundwater conditions and storage capacity in the San Joaquin Valley, California: U.S. Geological Survey Water-Supply Paper 1469, $277 \mathrm{p}$.

Deeley, G.M., Reinhard, Martin, and Sterns, S.M., 1991, Transformation and Sorption of 1,2-dibromomethane-3chloropropane in subsurface samples collected at Fresno, California: Journal of Environmental Quality, v. 20, no. 3, p. 547-556.

Domagalski, J.L., and Dubrovsky, N.M., 1991, Regional assessment of non-point source pesticide residues in ground water, San Joaquin Valley, California: U.S. Geological Survey Water-Resources Investigations Report 91-4027, $64 \mathrm{p}$.

Domagalski, J.L., 1997, Pesticides in surface and ground water of the San Joaquin-Tulare basins, California; analysis of available data, 1966 through 1992: U.S. Geological Survey Water-Supply Paper 2468, 74 p.

Dubrovsky, N.M., Deverel, S.J., and Gilliom, R.J., 1993, Multiscale approach to regional groundwater-quality assessment: Selenium in the San Joaquin Valley, California, in W.M. Alley, ed., Regional groundwater quality: New York, Van Nostrand Reinhold, p. 537-562.

Dubrovsky, N.M., Kratzer, C.R., Brown, L.R., Gronberg, J.M., and Burow, K.R., 1998, Water quality in the San JoaquinTulare Basins, California, 1992-95: U.S. Geological Survey Circular 1159, 38 p. (Also available at: http://pubs.usgs. gov/circ/circ1159/.) 
Faunt, C.C., ed., 2009, Groundwater availability of the Central Valley Aquifer, California: U.S. Geological Survey Professional Paper 1766, 225 p. (Also available at: http:// pubs.usgs.gov/pp/1766/.)

Gilliom, R.J., Barbash, J.E., Crawford, C.G., Hamilton, P.A., Martin, J.D., Nakagaki, N., Nowell, L.H., Scott, J.C., Stackelberg, P.E., Thelin, G.P., and Wolock, D.M., 2006, The quality of our nation's waters: Pesticides in the nation's streams and ground water, 1992-2001: U.S. Geological Survey Circular 1291, 172 p. (Also available at: http://pubs. usgs.gov/circ/2005/1291/.)

Helsel, D.R., and Hirsch, R.M., 2002, Statistical methods in water resources: U.S. Geological Survey Techniques of Water-Resources Investigations, Book 4, Chapter A3, 510 p. (Also available at: http://water.usgs.gov/pubs/twri/twri4a3/.)

Hem, J.D., 1992, Study and interpretation of the chemical characteristics of natural water, third edition: U.S. Geological Survey Water-Supply Paper 2254, 263 p.

Hotchkiss, W.R., and Balding, G.O., 1971, Geology, hydrology, and water quality of the Tracy-Dos Palos Area, San Joaquin Valley, California: U.S. Geological Survey Open-File Report, 107 p.

Hutson, S.S., Barber, N.L., Kenny, J.F., Linsey, K.S., Lumia, D.S., and Maupin, M.A., 2004, Estimated use of water in the United States in 2000: U.S. Geological Survey Circular $1268,46 \mathrm{p}$.

Ingebritsen, S.E., Ikehara, M.E., Galloway, D.L., and Jones, D.R., 2000, Delta subsidence in California: The Sinking Heart of the State: U.S. Geological Survey Fact Sheet 00500, 4 p. (Also available at: http://pubs.usgs.gov/fs/2000/ fs00500/.)

Isaaks, E.H., and Srivastava, R.M., 1989, Applied geostatistics: Oxford University Press, New York. 561 p.

Ivahnenko, Tammy, and Barbash, J.E., 2004, Chloroform in the hydrologic system-Sources, transport, fate, occurrence, and effects on human health and aquatic organisms: U.S. Geological Survey Scientific Investigations Report 2004-5137, 34 p. (Also available at: http://pubs.usgs.gov/ $\underline{\operatorname{sir} / 2004 / 5137 / .)}$

Izbicki, J.A., Metzger, L.F., McPherson, K.R., Everett, R.R., and Bennett V, G.L., 2006, Source of high-chloride water to wells, Eastern San Joaquin ground-water subbasin, California: U.S. Geological Survey Open-File Report 2006-1309, 8 p. (Also available at: http://pubs.usgs.gov/ of/2006/1309/.)
Izbicki, J.A., Stamos, C.L., Metzger, L.F., Kulp, T.R., McPherson, K.R., Halford, K.J., and Bennett, G.L., 2008, Sources, distribution, and management of arsenic in water from wells, Eastern San Joaquin ground-water subbasin, California: U.S. Geological Survey Open-File Report 2008-1272, 8 p. (Also available at: http://pubs.usgs.gov/ of/2008/1272/.)

Jennings, C.W., 1977, Geologic map of California: California Department of Conservation, Division of Mines and Geology, Geologic Data Map No. 2, scale 1:750,000.

Johnson, T.D., and Belitz, Kenneth, 2009, Assigning land use to supply wells for the statistical characterization of regional groundwater quality: Correlating urban land use and VOC occurrence: Journal of Hydrology, v. 370, p. 100-108.

Jurgens, B.C., Burow, K.R., Dalgish, B.A., and Shelton, J.L., 2008, Hydrogeology, water chemistry, and factors affecting the transport of contaminants in the zone of contribution to a public-supply well in Modesto, eastern San Joaquin Valley, California: U.S. Geological Survey Scientific Investigations Report 2008-5156, 78 p. (Also available at: http://pubs.usgs.gov/sir/2008/5156/.)

Jurgens, B.C., McMahon, P.B., Chapelle, F.H., and Eberts, S.M., 2009, An Excel ${ }^{\circledR}$ workbook for identifying redox processes in ground water: U.S. Geological Survey OpenFile Report 2009-1004, 8 p. (Also available at http://pubs. usgs.gov/of/2009/1004/.)

Kulongoski, J., and Belitz, Kenneth, 2004, Ground-water ambient monitoring and assessment program: U.S. Geological Survey Fact Sheet 2004-3088, 2 p. (Also available at: http://pubs.usgs.gov/fs/2004/3088/.)

Lucas, L.L., and Unterweger, M.P., 2000, Comprehensive review and critical evaluation of the half-life of Tritium: Journal of Research of the National Institute of Standards and Technology, v. 105 , no. 4, p. 541-549.

Marchand, D.E., and Allwardt, Alan, 1981, Late Cenozoic stratigraphic units, northeastern San Joaquin Valley, California: U.S. Geological Survey Bulletin 1470, 70 p.

McMahon, P.B., and Chapelle, F.H., 2008, Redox processes and water quality of selected principal aquifer systems: Ground Water, v. 46, no. 2, p. 29-271.

Michel, R.L., 1989, Tritium deposition in the continental United States, 1953-83: U.S. Geological Survey WaterResources Investigations Report 89-4072, 46 p.

Michel, R.L., and Schroeder, R., 1994, Use of long-term tritium records from the Colorado River to determine timescales for hydrologic processes associated with irrigation in the Imperial Valley, California: Applied Geochemistry v. 9, p. 387-401. 
Nakagaki, N., and Wolock, D.M., 2005, Estimation of agricultural pesticide use in drainage basins using land cover maps and county pesticide data: U.S. Geological Survey Open-File Report 2005-1188, 56 p. (Also available at http://pubs.usgs.gov/of/2005/1188/.)

Nakagaki, N., Price, C.V., Falcone, J.A., Hitt, K.J., and Ruddy, B.C., 2007, Enhanced National Land Cover Data (NLCDe 92): U.S. Geological Survey Raster Digital Data, accessed August 30, 2010, at http://water.usgs.gov/lookup/ getspatial?nlcde92.

Page, R.W., 1986, Geology of the fresh ground-water basin of the Central Valley, California, with texture maps and sections: U.S. Geological Survey Professional Paper 1401-C, $54 \mathrm{p}$.

Peoples, S.A., Maddy, K.T., Cusick, W.G., Jackson, T., Cooper, C., and Frederickson, A.S., 1980, A study of samples of well water collected from selected areas in California to determine the presence of $\mathrm{DBCP}$ and certain other pesticide residues: Bulletin of Environmental Contamination and Toxicology, v. 24, 611-618.

Phillips, S.P., Green, C.T., Burow, K.R., Shelton, J.L., and Rewis, D.L., 2007, Simulation of multiscale groundwater flow in part of the northeastern San Joaquin Valley, California: U.S. Geological Survey Scientific Investigations Report 2007-5009, 43 p. (Also available at: http://pubs.usgs. gov/sir/2007/5009/.)

Piper, A.M., Gale, H.S., Thomas, H.E., and Robinson, T.W., 1939, Geology and ground-water hydrology of the Mokelumne area, California: U.S. Geological Survey Water-Supply Paper 780, $230 \mathrm{p}$.

Piper, A.M., 1944, A graphic procedure in the geochemical interpretation of water analyses: American Geophysical Union Transactions, v. 25, p. 914-923.

Plummer, L.N., Michel, R.L., Thurman, E.M., and Glynn, P.D., 1993, Environmental tracers for age-dating young ground water, in Alley, W.M., ed., Regional ground-water quality: Van Nostrand Reinhold, New York, p. 255-294.

Rowe, B.L., Toccalino, P.L., Moran, M.J., Zogorski, J.S., and Price, C.V., 2007, Occurrence and potential human-health relevance of volatile organic compounds in drinking water from domestic wells in the United States: Environmental Health Perspectives, v, 115, no. 11, p. 1539-1546.

Scott, J.C., 1990, Computerized stratified random site selection approaches for design of a ground-water quality sampling network: U.S. Geological Survey Water-Resources Investigations Report 90-4101, 109 p.
Solomon, D.K., Poreda, R.J., Schiff, S.L., and Cherry, J.A., 1992, Tritium and helium 3 as groundwater age tracers in the Borden Aquifer: Water Resources Research, v. 28, no. 3, p. 241-755.

Solomon, D.K., and Cook, P.G., 2000, ${ }^{3} \mathrm{H}$ and ${ }^{3} \mathrm{He}$, in Cook, P.G., and Herczeg, A.L., eds., Environmental Tracers in Subsurface Hydrology: Kluwer Academic Press, Boston, p. $397-424$.

Stollenwerk, K., 2003, Geochemical processes controlling transport of arsenic in groundwater, in Welch, A.H., and Stollenwerk, K.G., eds., Arsenic in Ground Water Geochemistry and Occurrence: Boston, Kluwer Academic Publishers, p. 67-100.

Toccalino, P.L., Norman, J.E., Phillips, R.H., Kauffman, L.J., Stackelberg, P.E., Nowell, L.H., Krietzman, S.J., and Post, G.B., 2004, Application of health-based screening levels to ground-water quality data in a state-scale pilot effort: U.S. Geological Survey Scientific Investigations Report Scientific Investigations Report 2004-5174, 64 p. (Also available at: http://pubs.usgs.gov/sir/2004/5174/.)

Toccalino P.L., and Norman, J.E., 2006, Health-based screening levels to evaluate U.S. Geological Survey ground water quality data: Risk Analysis, v. 26, no. 5, p. 13391348 .

Tolstikhin, I.N., and Kamensky, I.L., 1969, Determination of ground-water ages by the T-3He method: Geochemistry International, v. 6, p. 310-811.

Torgersen, T., Clarke, W.B., and Jenkins, W.J., 1979, The tritium/helium-3 method in hydrology, in Isotope Hydrology 1978: Vienna, Austria: International Atomic Energy Agency, IAEA-SM-228/49, p. 917-930.

Troiano, J., Weaver, D., Marade, J., Spurlock, F., Pepple, M., Nordmark, C., and Bartkowiak, D., 2001, Summary of well water sampling in California to detect pesticide residues resulting from nonpoint source applications: Journal of Environmental Quality, v. 30, p. 448-459.

Urbansky, E.T., Brown, S.K., Magnuson, M.L., and Kelty, C.A., 2001, Perchlorate levels in samples of sodium nitrate fertilizer derived from Chilean caliche: Environmental Pollution, v. 112, p. 299-302.

U.S. Environmental Protection Agency, 1998, Code of Federal Regulations, title 40 - protection of environment, chapter 1 -environmental protection agency, subchapter Epesticide programs, part 159—-statements of policies and interpretations, subpart D-reporting requirements for risk/ benefit information, 40 CFR 159.184: National Archives and Records Administration, September 19, 1997; amended June 19, 1998, Accessed September 5, 2008, at http://www. epa.gov/EPA-PEST/1997/September/Day-19/p24937.htm. 
U.S. Environmental Protection Agency, 2000, 1,2-Dibromo3-Chloropropane (DBCP) Hazard Summary: U.S. Environmental Protection Agency, Technology Transfer Network Air Toxics Web Site, accessed May 27, 2010, at http://www.epa.gov/ttn/atw/hlthef/dibromo-.html.

U.S. Environmental Protection Agency, 2006, 2006 Edition of the Drinking Water Standards and Health Advisories, updated August 2006: U.S. Environmental Protection Agency, Office of Water EPA/822/R-06-013, http://www. epa.gov/waterscience/criteria/drinking/dwstandards.pdf.

Weissmann, G.S., Mount, J.F., and Fogg, G.E., 2002, Glacially driven cycles in accumulation space and sequence stratigraphy of a stream-dominated alluvial fan, San Joaquin Valley, California, USA: Journal of Sedimentary Research, v. 72 , no. 2 , p. $240-251$.

Weissmann, G.S., Yong, Z. Fogg, G.E., and Mount, J.F., 2004, Influence of incised valley fill deposits on hydrogeology of a glacially-influenced, stream-dominated alluvial fan, in Society for Sedimentary Geology Special Publication 80, p. $15-28$.
Weissmann, G.S., Bennett, G.L., and Lansdale, A.L., 2005, Factors controlling sequence development on Quaternary fluvial fans, San Joaquin Basin, California, USA, in Harvey, A.M., Mather, A.E., and Stokes, M. (eds.) Alluvial Fans: Geomorphology, Sedimentology, Dynamics: Geological Society, London, Special Publications, 251, p.169-186.

Welch, A.H., Oremland, R.S., Davis, J.A., and Watkins, S.A., 2006, Arsenic in ground water: a review of current knowledge and relation to the CALFED solution area with recommendations for needed research: San Francisco Estuary and Watershed Science, v. 4, no. 2, Article 4, 32 p., accessed May 19, 2008, at http://repositories.cdlib.org/jmie/ sfews/vol4/iss2/art4/.

Zogorski, J.S., Carter, J.M., Ivahnenko, T., Lapham, W.W., Moran, M.J., Rowe, B.L., Squillace, P.J., and Toccalino, P.L., 2006, Volatile organic compounds in the Nation's ground water and drinking water supply wells: U.S. Geological Survey Circular 1292, 101 p. (Also available at: http://pubs.usgs.gov/circ/circ1292/.) 


\section{Appendix A. Selection of CDPH Well Data}

For the Northern San Joaquin Basin study unit, the historical CDPH database (January 10, 1984-April 21, 2004) contains more than 300,000 records containing information from more than 900 wells, requiring targeted retrievals to manageably use the data to assess water quality. The paragraphs below summarize the selection process for wells and data from the CDPH database for use in the grid-based status assessment.

For the status assessment, additional CDPH inorganic constituent data were needed to supplement the grid in areas where the USGS did not have inorganic constituent data. This involved prioritizing data from different sources. The first choice was to select CDPH inorganic constituent data for a grid well where the USGS measured other constituents, provided that the CDPH data met quality-control criteria. Cation-anion balance was used as the quality-control assessment metric. Because water is electrically neutral and must have a balance between positive (cations) and negative (anions) electrically charged dissolved species, the cation/ anion balance commonly is used as a quality-assurance check for water sample analysis (Hem, 1992). An imbalance of equal to or greater than 10 percent indicates uncertainty in the quality of the data. The most recent $\mathrm{CDPH}$ data from the USGS-grid well were evaluated to determine whether the $\mathrm{CDPH}$ data had a cation/anion imbalance less than 10 percent. If so, those data were selected for use as grid-well data for inorganic constituents. It was assumed that analyses with high-quality major-ion data also had high-quality data for trace elements, nutrients, and radiochemical constituents. For identification purposes, data from the $\mathrm{CDPH}$ for these grid wells were assigned identification numbers equivalent to those of the USGS-grid well but with ' $\mathrm{D}$ ' inserted between the study area prefix and sequence number (for example, $\mathrm{CDPH}$-grid well COS-D-01 is the same well as USGS-grid well COS-01, table A1).

If the first step did not yield acceptable CDPH inorganic constituent data for a grid cell, the second step was to rank the CDPH wells for the cell randomly and choose the highest ranked well with a cation/anion imbalance less than 10 percent. These second-choice CDPH-grid wells were not co-located with the USGS-grid wells. If no CDPH wells in a grid cell met the charge-balance criterion or there were insufficient data to evaluate charge balance, the third choice for the CDPH-grid well was to select the highest randomly ranked CDPH well, for the cell, that had any of the needed inorganic constituent data, which could include USGSgrid wells that did not meet the criteria in the first step. For identification purposes, data from the $\mathrm{CDPH}$ for these grid wells were assigned identifications numbers equivalent to the USGS- grid well but with 'DG' inserted between the study area prefix and sequence number (for example, $\mathrm{CDPH}$-grid well COS-DG-06 is in the same cell but is not the same well as USGS-grid well COS-06, table A1).

Empty cells, that is, those that were not sampled by the USGS, were checked for CDPH wells that could be added to the grid using the steps described above. For identification purposes, data from CDPH for these selected grid wells were assigned identification numbers equivalent to those of the USGS wells but with 'DHS' inserted between the study area prefix and sequence number (for example, CDPH-grid well COS-DHS-11 is in a grid cell where there are no USGS wells, table A1). CDPH-grid wells added to previously unsampled cells were given the next available sequence number.

Analysis of the combined datasets to evaluate the occurrence of high or moderate relative-concentrations was not affected by differences in reporting levels (LRLs or MDLs) between USGS-GAMA and CDPH data because concentrations greater than one-half of water-quality benchmarks were substantially higher than the highest LRLs or MDLs.

The locations and identification numbers of grid and understanding wells are shown in figure A1. Several types of comparisons between USGS-collected and CDPH data are described in appendix D: Comparison of CDPH and USGS-GAMA data. 
Table A1. Nomenclature for wells sampled by USGS or selected from the CDPH database for the Northern San Joaquin Basin Groundwater Ambient Monitoring and Assessment (GAMA) study unit.

[COS, Cosumnes study area grid well; ESJ, Eastern San Joaquin study area grid well; NSJ-QPC, Upland study area grid well; TRCY, Tracy study area grid well; USGS, U.S. Geological Survey: Abbreviations associated with well names: D, USGS sampled well with supplemental CDPH data; DG, non-USGS sampled CDPH well selected to supplement USGS data in the same grid cell; DHS, non-USGS sampled CDPH well selected in a cell with no USGS data; FP, flow-path well]

\begin{tabular}{lcc}
\hline \multirow{2}{*}{$\begin{array}{c}\text { Grid or understanding } \\
\text { well sampled by GAMA }\end{array}$} & \multicolumn{2}{c}{ Grid supplemented by CDPH data from a } \\
\cline { 2 - 3 } & USGS-grid well & Different well \\
\hline
\end{tabular}

Northern San Joaquin grid wells

\begin{tabular}{|c|c|c|}
\hline COS-01 & COS-D-01 & - \\
\hline COS-02 & - & - \\
\hline COS-03 & COS-D-03 & - \\
\hline COS-04 & COS-D-04 & - \\
\hline COS-05 & - & - \\
\hline COS-06 & - & COS-DG-06 \\
\hline COS-07 & - & - \\
\hline COS-08 & COS-D-08 & - \\
\hline COS-09 & - & COS-DG-09 \\
\hline COS-10 & COS-D-10 & - \\
\hline- & - & COS-DHS-11 \\
\hline - & - & COS-DHS-12 \\
\hline- & - & COS-DHS-13 \\
\hline ESJ-01 & ESJ-D-01 & - \\
\hline ESJ-02 & ESJ-D-02 & - \\
\hline ESJ-03 & ESJ-D-03 & - \\
\hline ESJ-04 & - & - \\
\hline ESJ-05 & ESJ-D-05 & - \\
\hline ESJ-06 & ESJ-D-06 & - \\
\hline ESJ-07 & ESJ-D-07 & - \\
\hline ESJ-08 & ESJ-D-08 & - \\
\hline ESJ-09 & ESJ-D-09 & - \\
\hline ESJ-10 & - & - \\
\hline ESJ-11 & ESJ-D-11 & - \\
\hline ESJ-12 & - & - \\
\hline ESJ-13 & ESJ-D-13 & - \\
\hline ESJ-14 & - & - \\
\hline ESJ-15 & ESJ-D-15 & - \\
\hline ESJ-16 & ESJ-D-16 & - \\
\hline ESJ-17 & - & ESJ-DG-17 \\
\hline ESJ-18 & ESJ-D-18 & - \\
\hline ESJ-19 & - & - \\
\hline- & - & ESJ-DHS-20 \\
\hline NSJ-QPC-01 & - & - \\
\hline NSJ-QPC-02 & NSJ-QPC-D-02 & - \\
\hline
\end{tabular}

\begin{tabular}{|c|c|c|}
\hline \multirow{2}{*}{$\begin{array}{l}\text { Grid or understanding } \\
\text { well sampled by GAMA }\end{array}$} & \multicolumn{2}{|c|}{ Grid supplemented by CDPH data from a } \\
\hline & USGS-grid well & Different well \\
\hline \multicolumn{3}{|c|}{ Northern San Joaquin grid wells_-Continued } \\
\hline NSJ-QPC-03 & NSJ-QPC-D-03 & - \\
\hline NSJ-QPC-04 & NSJ-QPC-D-04 & - \\
\hline NSJ-QPC-05 & - & NSJ-QPC-DG-05 \\
\hline NSJ-QPC-06 & - & - \\
\hline NSJ-QPC-07 & NSJ-QPC-D-07 & - \\
\hline NSJ-QPC-08 & NSJ-QPC-D-08 & - \\
\hline NSJ-QPC-09 & NSJ-QPC-D-09 & - \\
\hline NSJ-QPC-10 & NSJ-QPC-D-10 & - \\
\hline NSJ-QPC-11 & - & NSJ-QPC-DG-11 \\
\hline TRCY-01 & TRCY-D-01 & - \\
\hline TRCY-02 & - & TRCY-DG-02 \\
\hline TRCY-03 & - & - \\
\hline TRCY-04 & TRCY-D-04 & - \\
\hline TRCY-05 & - & TRCY-DG-05 \\
\hline TRCY-06 & - & TRCY-DG-06 \\
\hline TRCY-07 & - & - \\
\hline TRCY-08 & - & TRCY-DG-08 \\
\hline TRCY-09 & TRCY-D-09 & - \\
\hline TRCY-10 & - & - \\
\hline TRCY-11 & TRCY-D-11 & - \\
\hline- & - & TRCY-DHS-12 \\
\hline- & - & TRCY-DHS-13 \\
\hline- & - & TRCY-DHS-14 \\
\hline
\end{tabular}

Northern San Joaquin understanding wells

ESJFP-07
ESJFP-08
ESJFP-09
ESJFP-10
TRCYFP-01
TRCYFP-02
TRCYFP-03
TRCYFP-04
TRCYFP-05
TRCYFP-06




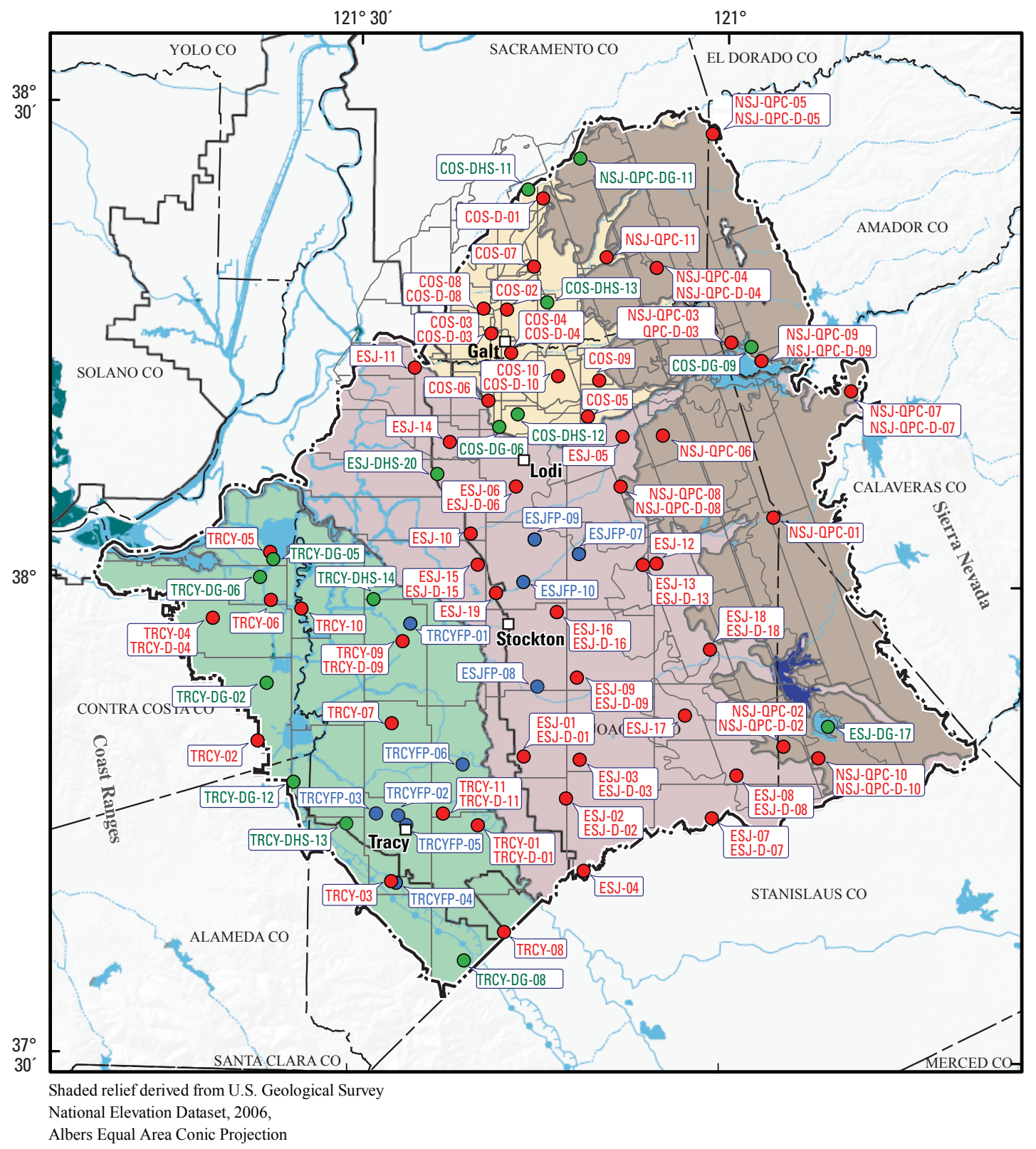

Delta Boundary - Section 12220 of the Water Code

North American Datum of 1983 (NAD 83)

\section{Study ares}
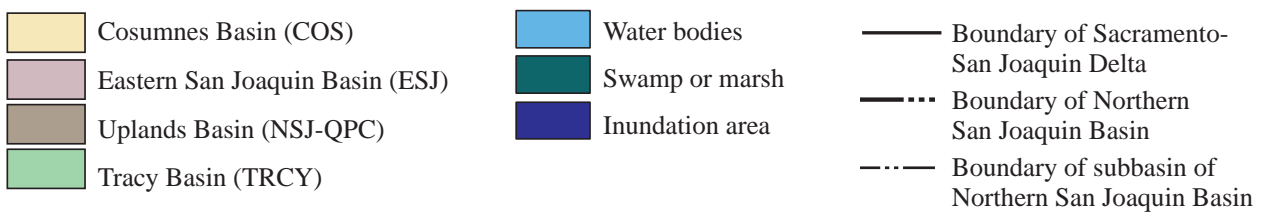

Grid well (USGS)

○ Understanding well (USGS)

Grid Well (CDPH) Northern San J oaquin Basin

Figure A1. Map showing identifiers and locations of grid and understanding wells sampled during December 2004-February 2005, and grid wells at which data for inorganic constituents from the California Department of Public Health were used, Northern San Joaquin Basin Groundwater Ambient Monitoring and Assessment (GAMA) study unit 


\section{Appendix B. Ancillary Datasets}

\section{Land Use}

Land use was classified using the satellite-derived (30-m pixel resolution) nationwide USGS National Land Cover Dataset (Nakagaki and others, 2007). This dataset has been used in previous national and regional studies relating land use to water quality (Gilliom and others, 2006; Zogorski and others, 2006). The data represent land use during the early 1990s. The imagery is classified into 25 land-cover classifications (Nakagaki and Wolock, 2005). These 25 land-cover classifications were assigned to three general classifications for the purpose of general categorization of principal land use in the study unit: urban, agricultural, and natural. Land-use statistics for the study unit, the study areas, and a circular buffer of a 500-m radius around each well were computed for datasets using ArcGIS (version 9.2) (table B1) (Johnson and Belitz, 2009).

\section{Well Depth and Depth to Top-of-Perforation}

Well depth and depth to top-of-perforation are used as explanatory factors in the understanding assessment. Well-construction data were determined primarily from drillers' logs. More rarely, well-construction data were obtained from ancillary records of well owners or the USGS National Water Information System database. Well construction information is shown in table B2.

\section{Normalized Lateral Position}

The normalized lateral position of wells serves as a proxy for the horizontal position in the regional groundwater flow system. Regionally, the direction of groundwater flow primarily is from the eastern and western margins of the valley deposits along the Sierra Mountain front and the Coast Ranges, respectively, towards the San Joaquin River (fig. 6). The groundwater flow system has vertical and horizontal flow components that deviate from the general direction in response to groundwater withdrawals and recharge (Phillips and others, 2007). Nevertheless, because the predominant pattern of regional groundwater flow is from the valley margins towards the San Joaquin River, normalized lateral position serves as an approximate indicator of relative position of a well within the regional flow system. The normalized lateral position of each well was calculated as the ratio of the distance from the well to the upgradient edge of the regional groundwater flow system (valley margin) to the total distance from the center of the valley (valley trough) to the valley margin. The east and west edges of the valley (valley margins) are represented by the boundaries of the valley fill deposits, and wells located here were assigned a value of 1 and represent the upgradient end of regional flow. In the Northern San Joaquin, the center of the valley (valley trough) was represented by the position of the San Joaquin River, and wells located here were assigned a value of 0 and represent the downgradient end of regional flow. Both boundaries were represented as approximate line segments and normalized lateral position was calculated along lines perpendicular to both boundaries (fig. 9). The normalized lateral position was calculated for all 30 by $30-\mathrm{m}$ wide cells in the San Joaquin Valley as part of a regional groundwater flow modeling study (Faunt, 2009). ArcGIS (version 9.2) was used to assign normalized lateral position values to all wells residing within those cells (table B2). Higher values of normalized lateral position indicate locations closer to the valley margin or in the upgradient (proximal) part of the flow system and lower values of normalized lateral position indicate locations closer to the valley trough or the downgradient (distal) part of the flow system.

\section{Groundwater Age}

Groundwater age-dating techniques provide a measure of the time since the groundwater was last in contact with the atmosphere. Techniques aimed at estimating groundwater residence time or "age" in this study was based on concentrations of tritium $\left({ }^{3} \mathrm{H}\right)$ (Tolstikhin and Kamensky, 1969; Torgersen and others, 1979; Solomon and others, 1992).

${ }^{3} \mathrm{H}$ is a short-lived radioactive isotope of hydrogen with a half-life of 12.32 years (Lucas and Unterweger, 2000). ${ }^{3} \mathrm{H}$ is produced naturally in the atmosphere from the interaction of cosmogenic radiation with nitrogen (Craig and Lal, 1961), by above-ground nuclear explosions, and by the operation of nuclear reactors. Tritium enters the hydrologic cycle following oxidation to tritiated water (HTO). Consequently, the presence of ${ }^{3} \mathrm{H}$ in groundwater is used to identify water that has exchanged with the atmosphere in the past 50 years.

In this study, groundwater with tritium activities less than 1 tritium unit (TU) were categorized as old (table B3). Old groundwater is defined as having recharged prior to about 1950 . The category old could include groundwater that recharged from 56 to tens of thousands of years ago. Groundwater with tritium activities greater than $1 \mathrm{TU}$ was categorized as young. Young groundwater is defined as having recharged after about 1950. In reality, old groundwater could contain small fractions of young water, and young groundwater could contain small fractions of old water. Previous investigations have used a range of tritium concentrations from 0.3 to $1.0 \mathrm{TU}$ as thresholds for this distinction (Michel, 1989; Plummer and others, 1993, p. 260; Michel and Schroeder, 1994; Clark and Fritz, 1997, p. 185). By using a tritium concentration of $1.0 \mathrm{TU}$, at the upper end of the range used in the literature, for the threshold in this study, the age classification scheme allows a slightly larger fraction of young water to be present in an age distribution categorized as old than if a lower threshold were used. 
Table B1. Land-use classification for wells sampled by USGS or selected from CDPH database for the Northern San Joaquin Basin Groundwater Ambient Monitoring and Assessment (GAMA) study unit.

[Land-use classification is based on 500-meter buffer from Johnson and Belitz (2009). COS, Cosumnes study area grid well; ESJ, Eastern San Joaquin study area grid well; NSJ-QPC, Upland study area grid well; TRCY, Tracy study area grid well; USGS, U.S. Geological Survey: Abbreviations associated with well names: D, USGS sampled well with supplemental CDPH data; DG, non-USGS sampled CDPH well selected to supplement USGS data in the same grid cell; DHS, non-USGS sampled CDPH well selected in a cell with no USGS data; FP, flow-path well]

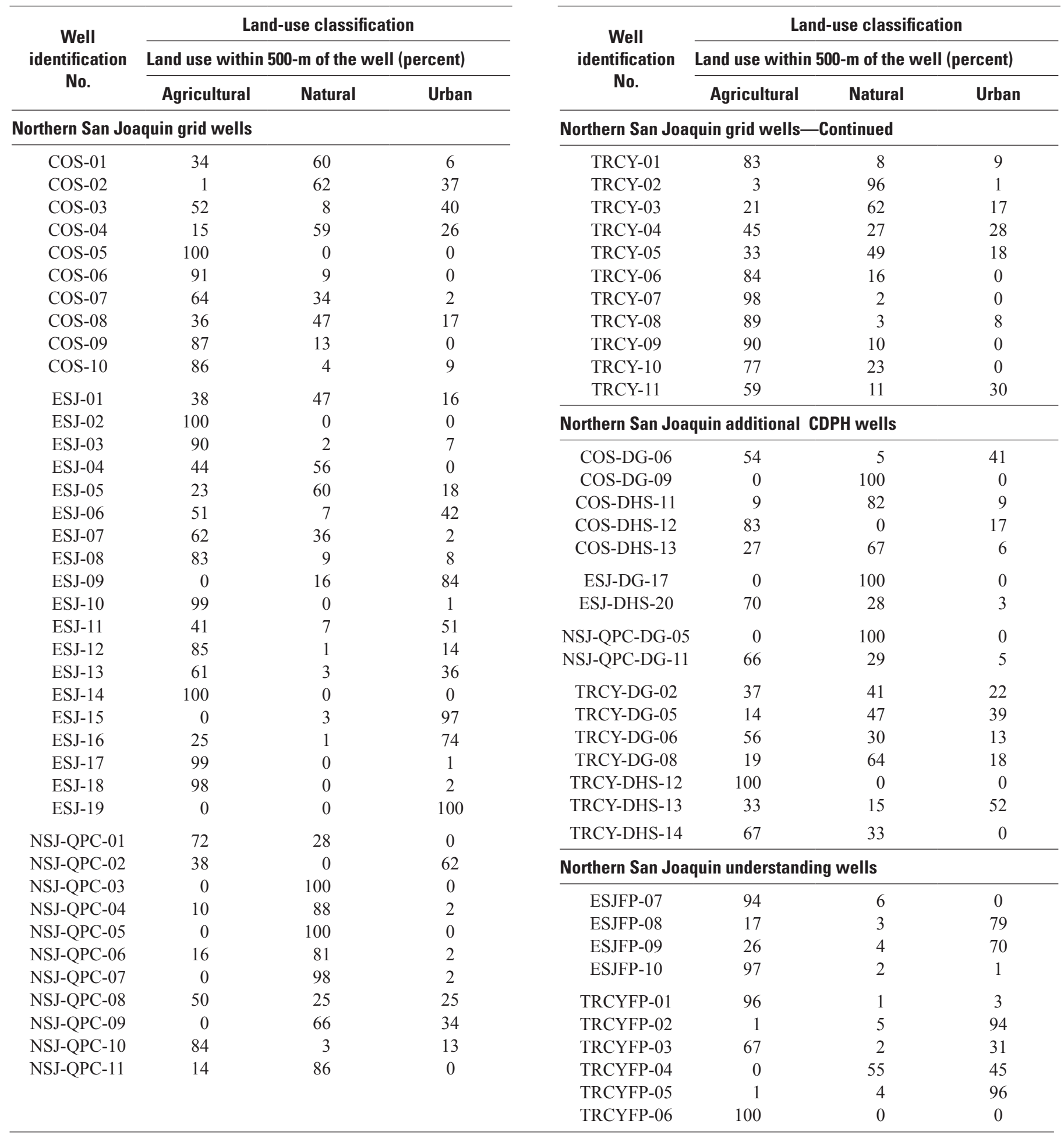


Table B2. Well construction and normalized lateral position information for wells sampled by USGS or selected from the CDPH database for the Northern San Joaquin Basin Groundwater Ambient Monitoring and Assessment (GAMA) study unit.

[Normalized lateral position: Values of normalized lateral position range from 0 to 1 . Values of 0 represent the valley trough (basin center), and values of 1 represent the valley margins (basin edges). COS, Cosumnes study area grid well; ESJ, Eastern San Joaquin study area grid well; NSJ-QPC, Upland study area grid well; TRCY, Tracy study area grid well; LSD, land-surface datum; USGS, U.S. Geological Survey: Abbreviations associated with well names: D, USGS sampled well with supplemental CDPH data; DG, non-USGS sampled CDPH well selected to supplement USGS data in the same grid cell; DHS, non-USGS sampled CDPH well selected in a cell with no USGS data; FP, flow-path well; - -, not available]

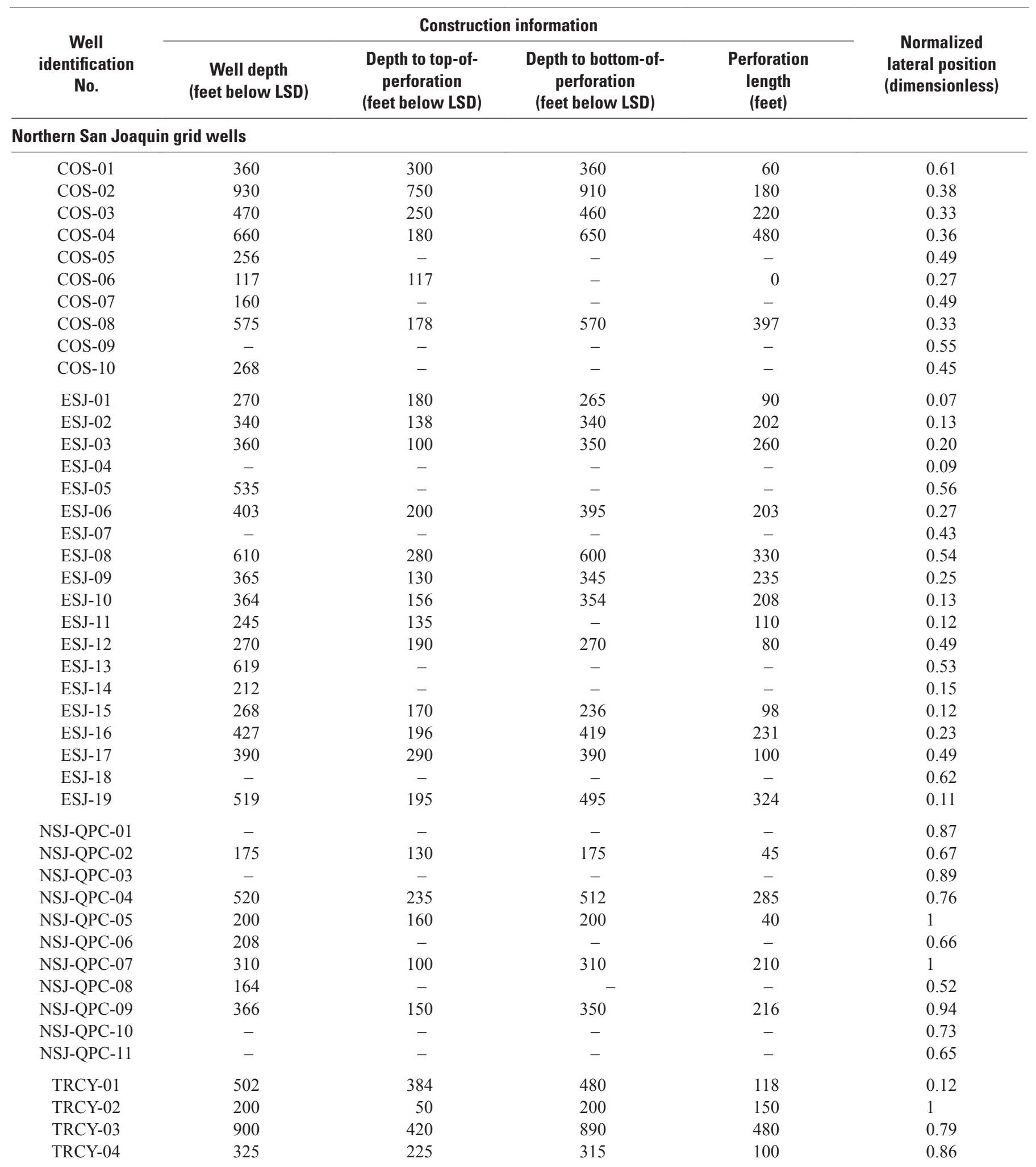


Table B2. Well construction and normalized lateral position information for wells sampled by USGS or selected from the CDPH database for the Northern San Joaquin Basin Groundwater Ambient Monitoring and Assessment (GAMA) study unit.—Continued

[COS, Cosumnes study area grid well; ESJ, Eastern San Joaquin study area grid well; NSJ-QPC, Upland study area grid well; TRCY, Tracy study area grid well; ft, feet; m, meter; LSD, land surface datum; USGS, U.S. Geological Survey: Abbreviations associated with well names: D, USGS sampled well with supplemental CDPH data; DG, non-USGS sampled CDPH well selected to supplement USGS data in the same grid cell; DHS, non-USGS sampled CDPH well selected in a cell with no USGS data; FP, flow-path well; - , not available]

\begin{tabular}{|c|c|c|c|c|c|}
\hline \multirow{2}{*}{$\begin{array}{c}\text { Well } \\
\text { identification } \\
\text { No. }\end{array}$} & \multicolumn{4}{|c|}{ Construction information } & \multirow{2}{*}{$\begin{array}{l}\text { Normalized } \\
\text { lateral position } \\
\text { (dimensionless }\end{array}$} \\
\hline & $\begin{array}{c}\text { Well depth } \\
\text { (feet below LSD) }\end{array}$ & $\begin{array}{l}\text { Depth to top-of- } \\
\text { perforation } \\
\text { (feet below LSD) }\end{array}$ & $\begin{array}{l}\text { Depth to bottom-of- } \\
\text { perforation } \\
\text { (feet below LSD) }\end{array}$ & $\begin{array}{l}\text { Perforation } \\
\text { length } \\
\text { (feet) }\end{array}$ & \\
\hline \multicolumn{6}{|c|}{ Northern San Joaquin grid wells-Continued } \\
\hline TRCY-05 & 380 & - & - & - & 0.34 \\
\hline TRCY-06 & - & - & - & - & 0.48 \\
\hline TRCY-07 & 83 & 23 & 73 & 60 & 0.41 \\
\hline TRCY-08 & 340 & 320 & 340 & 20 & 0.37 \\
\hline TRCY-09 & - & - & - & - & 0.15 \\
\hline TRCY-10 & 185 & 175 & 185 & 10 & 0.43 \\
\hline TRCY-11 & 400 & 310 & 400 & 90 & 0.32 \\
\hline \multicolumn{6}{|c|}{ Northern San Joaquin additional CDPH grid wells } \\
\hline COS-DG-06 & - & - & - & - & - \\
\hline COS-DG-09 & - & - & - & - & - \\
\hline COS-DHS-11 & - & - & - & - & 0.57 \\
\hline COS-DHS-12 & - & - & - & - & 0.33 \\
\hline COS-DHS-13 & 450 & 160 & - & 290 & 0.48 \\
\hline ESJ-DG-17 & - & - & - & - & - \\
\hline ESJ-DHS-20 & - & - & - & - & 0.10 \\
\hline NSJ-QPC-DG-05 & - & - & - & - & - \\
\hline NSJ-QPC-DG-11 & 240 & - & - & - & - \\
\hline TRCY-DG-02 & - & - & - & - & - \\
\hline TRCY-DG-05 & - & - & - & - & - \\
\hline TRCY-DG-06 & - & - & - & - & - \\
\hline TRCY-DG-08 & 730 & 180 & 690 & 550 & - \\
\hline TRCY-DHS-12 & 72 & - & - & - & 0.97 \\
\hline TRCY-DHS-13 & 95 & 75 & 95 & 20 & 0.83 \\
\hline TRCY-DHS-14 & 235 & - & - & - & 0.14 \\
\hline \multicolumn{6}{|c|}{ Northern San Joaquin understanding wells } \\
\hline ESJFP-07 & 466 & - & - & - & 0.33 \\
\hline ESJFP-08 & 425 & 199 & 415 & 226 & 0.14 \\
\hline ESJFP-09 & 300 & 162 & 288 & 138 & 0.27 \\
\hline ESJFP-10 & 540 & 200 & 520 & 340 & 0.18 \\
\hline TRCYFP-01 & 130 & 90 & 130 & 40 & 0.07 \\
\hline TRCYFP-02 & 1,148 & 337 & 1,128 & 811 & 0.56 \\
\hline TRCYFP-03 & 400 & - & - & - & 0.66 \\
\hline TRCYFP-04 & 860 & 420 & 850 & 440 & 0.77 \\
\hline TRCYFP-05 & 990 & 490 & 980 & 500 & 0.56 \\
\hline TRCYFP-06 & 148 & 128 & 148 & 20 & 0.10 \\
\hline
\end{tabular}


Table B3. Summary of tritium data from samples of unfiltered water and classification of samples into young and old categories, Northern San Joaquin Basin Groundwater Ambient Monitoring and Assessment (GAMA) study unit.

[COS, Cosumnes study area grid well; ESJ, Eastern San Joaquin study area grid well; NSJ-QPC, Upland study area grid well; TRCY, Tracy study area grid well; FP, flow-path well]

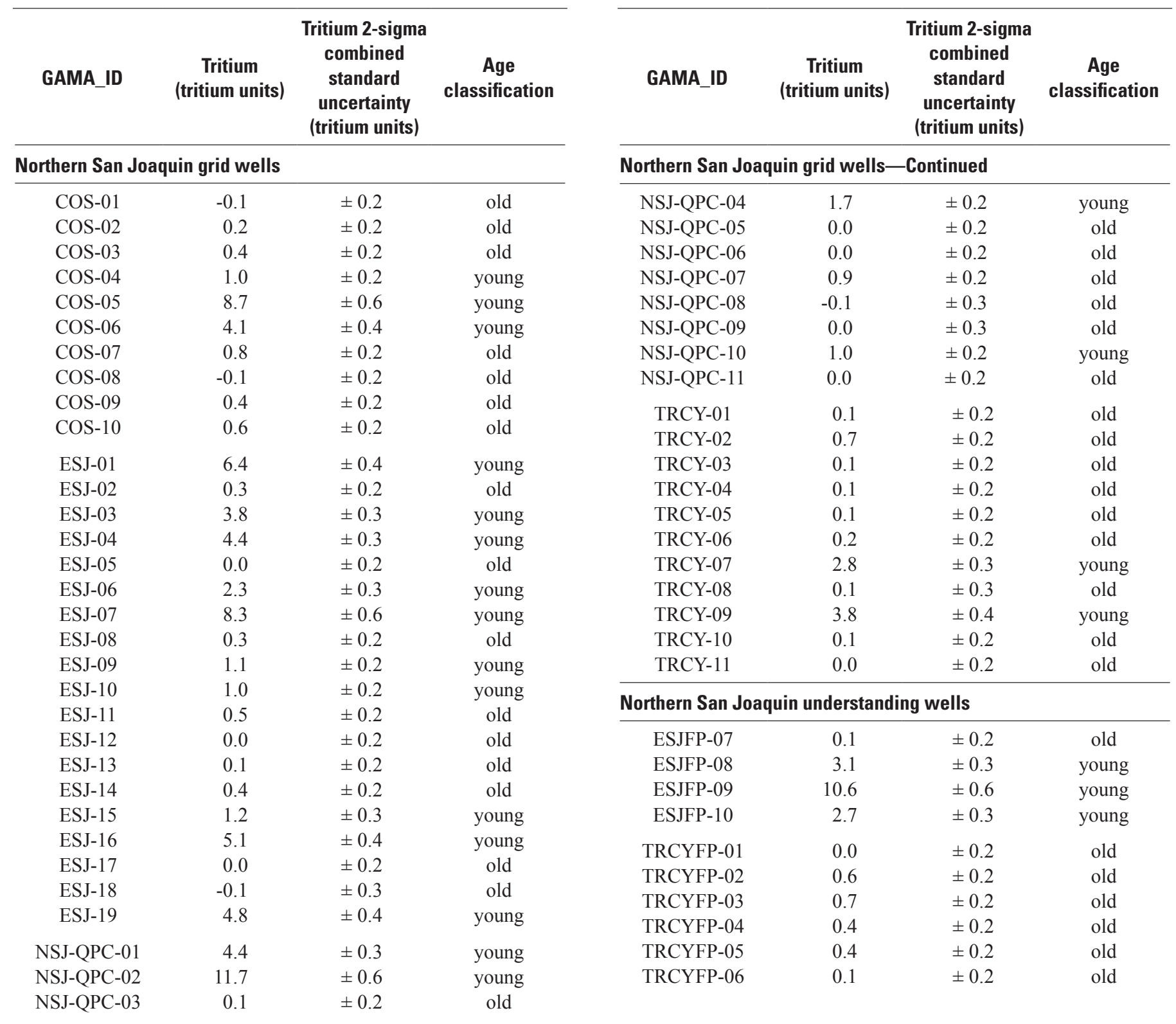




\section{Geochemical Conditions}

Geochemical conditions investigated as potential explanatory factors were oxidation-reduction characteristics (redox) and $\mathrm{pH}$. Redox conditions influence the transport of many organic and inorganic constituents by controlling whether the constituent is in a dissolved or adsorbed oxidation state (McMahon and Chapelle, 2008). Redox conditions along groundwater flow paths commonly proceed along a well-documented sequence of terminal electron-accepting processes (TEAP), in which a single TEAP typically dominates at a particular time and location within the aquifer (Chapelle and others, 1995; Chapelle, 2001). The predominant TEAPs are oxygen-reducing (oxic), nitrate-reducing, manganese-reducing, iron-reducing, sulfate-reducing, and methanogenic.

Classifications of redox condition were made by using the framework of McMahon and Chapelle (2008), for grid and understanding wells with available measurements of redox-sensitive constituents (dissolved oxygen, nitrate, iron, manganese, and sulfate). An automated workbook program was used to assign the redox classification to each sample
(Jurgens and others, 2009). Of the 61 wells with analyses of one or more redox-sensitive constituents, only 53 had information sufficient to make a determination of redox condition (table B4). In some cases, determinations were made on as few as two constituents. A key component to the accurate classification of redox conditions using the McMahon and Chapelle (2008) framework is availability of dissolved oxygen (DO) data, which were lacking in many wells sampled in the Northern San Joaquin Basin study unit. Using the McMahon and Chapelle (2008) framework, wells with fewer than four redox indicators often were categorized as belonging to a "mixed" redox category, a rare occurrence where both oxic and anoxic conditions are indicated by the sample, but which can occur in wells that have long screens, which can integrate water from multiple depths of the aquifer. Samples assigned to mixed categories were recategorized as either oxic or anoxic, based on the available redox information. For example, samples having only measurements of iron, manganese, and sulfate were evaluated based on the relative abundance of each constituent in the sample. Higher concentrations of these constituents (greater than the threshold value used by the McMahon and Chapelle (2008) redox framework) generally indicate reducing conditions.

Table B4. Concentrations of constituents used to classify geochemical (redox) conditions in groundwater, Northern San Joaquin Basin Groundwater Ambient Monitoring and Assessment (GAMA) study unit.

$\left[\mathrm{O}_{2}\right.$, oxygen reducing; redox, oxidation-reduction; $\mathrm{mg} / \mathrm{L}$, milligram per liter; $\mu \mathrm{g} / \mathrm{L}$, microgram per liter; oxic, dissolved oxygen $>0.5$; anoxic, dissolved oxygen $<0.5$ but no other redox indicators available; suboxic, dissolved oxygen $<0.5$ but redox status can not be further discerned because multiple indicators are below thresholds; $\mathrm{NO}_{3}$, nitrate reducing; $\mathrm{Mn}(\mathrm{IV})$, manganese reducing; Fe(III), iron reducing; ?, insufficient data to determine whether process is occurring or not; I, and(or); -, and; -, not analyzed/not available; >, greater than; <, less than]

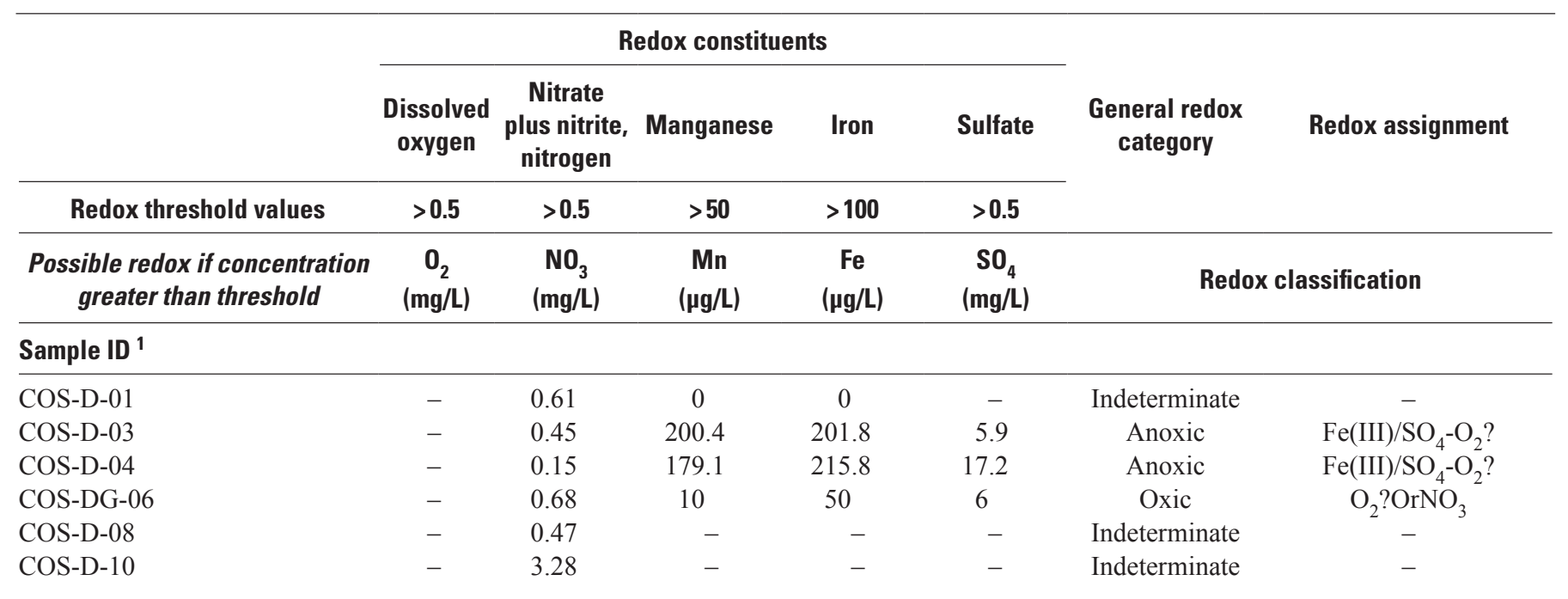


Table B4. Concentrations of constituents used to classify geochemical (redox) conditions in groundwater, Northern San Joaquin Basin Groundwater Ambient Monitoring and Assessment (GAMA) study unit.—Continued

$\left[\mathrm{O}_{2}\right.$, oxygen reducing; redox, oxidation-reduction; $\mathrm{mg} / \mathrm{L}$, milligram per liter; $\mu \mathrm{g} / \mathrm{L}$, microgram per liter; oxic, dissolved oxygen $>0.5$; anoxic, dissolved oxygen $<0.5$ but no other redox indicators available; suboxic, dissolved oxygen $<0.5$ but redox status can not be further discerned because multiple indicators are below thresholds; $\mathrm{NO}_{3}$, nitrate reducing; $\mathrm{Mn}(\mathrm{IV})$, manganese reducing; $\mathrm{Fe}(\mathrm{III})$, iron reducing; ?, insufficient data to determine whether process is occurring or not; /, and(or); -, and; -, not analyzed/not available; >, greater than; $<$, less than]

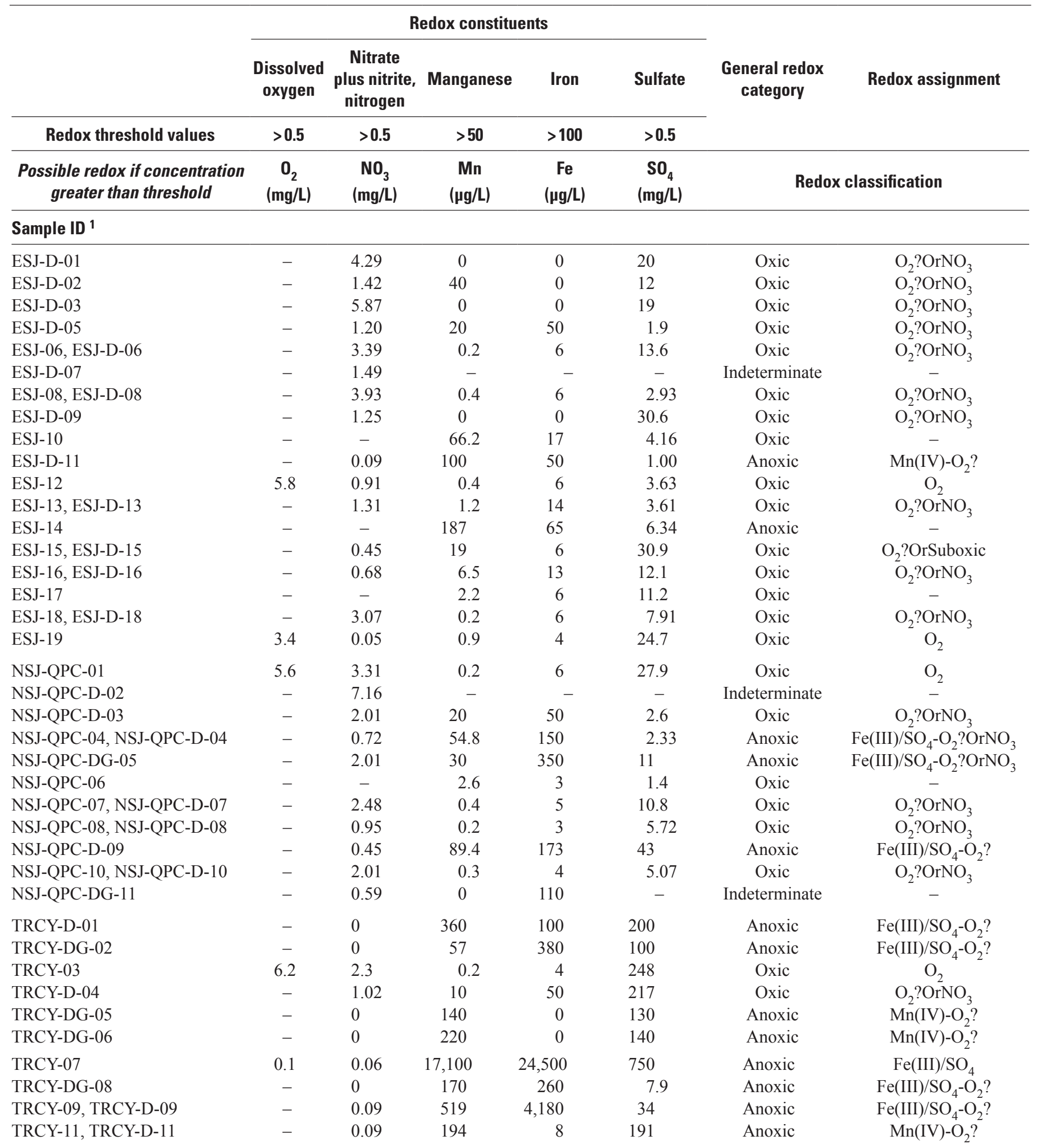


Table B4. Concentrations of constituents used to classify geochemical (redox) conditions in groundwater, Northern San Joaquin Basin Groundwater Ambient Monitoring and Assessment (GAMA) study unit.—Continued

$\left[\mathrm{O}_{2}\right.$, oxygen reducingredox, oxidation-reduction; $\mathrm{mg} / \mathrm{L}$, milligram per liter; $\mu \mathrm{g} / \mathrm{L}$, microgram per liter; oxic, dissolved oxygen $>0.5$; anoxic, dissolved oxygen $<$ 0.5 but no other redox indicators available; suboxic, dissolved oxygen $<0.5$ but redox status can not be further discerned because multiple indicators are below thresholds; $\mathrm{NO}_{3}$, nitrate reducing; $\mathrm{Mn}(\mathrm{IV})$, manganese reducing; $\mathrm{Fe}(\mathrm{III})$, iron reducing; ?, insufficient data to determine whether process is occurring or not; /, and(or); -, and; -, not analyzed/not available; >, greater than; $<$, less than]

\begin{tabular}{|c|c|c|c|c|c|c|c|}
\hline & \multicolumn{5}{|c|}{ Redox constituents } & $\begin{array}{l}\text { General redox } \\
\text { category }\end{array}$ & Redox assignment \\
\hline Redox threshold values & $>0.5$ & $>0.5$ & $>50$ & $>100$ & $>0.5$ & & \\
\hline $\begin{array}{c}\text { Possible redox if concentration } \\
\text { greater than threshold }\end{array}$ & $\begin{array}{c}\mathrm{O}_{2} \\
(\mathrm{mg} / \mathrm{L})\end{array}$ & $\begin{array}{l}\mathrm{NO}_{3} \\
(\mathrm{mg} / \mathrm{L})\end{array}$ & $\begin{array}{c}\text { Mn } \\
(\mu \mathrm{g} / \mathrm{L})\end{array}$ & $\begin{array}{c}\mathrm{Fe} \\
(\mu \mathrm{g} / \mathrm{L})\end{array}$ & $\begin{array}{c}\mathrm{SO}_{4} \\
(\mathrm{mg} / \mathrm{L})\end{array}$ & \multicolumn{2}{|c|}{ Redox classification } \\
\hline \multicolumn{8}{|l|}{ Sample ID ${ }^{1}$} \\
\hline COS-DHS-11 & - & 0.45 & - & - & - & Indeterminate & - \\
\hline COS-DHS-12 & - & 0.38 & 90 & 50 & 7 & Anoxic & $\mathrm{Mn}(\mathrm{IV})-\mathrm{O}_{2} ?$ \\
\hline COS-DHS-13 & - & 1.83 & 0 & 0 & - & Indeterminate & - \\
\hline ESJ-DHS-20 & - & 5.20 & 18 & 50 & 18 & Oxic & $\mathrm{O}_{2}$ ? OrNO 3 \\
\hline ESJFP-07 & - & 0.54 & 0.8 & 4 & 6.05 & Oxic & $\mathrm{O}_{2}$ ? $\mathrm{OrNO}_{3}$ \\
\hline ESJFP-08 & - & - & 87.9 & 13 & 18.8 & Anoxic & - \\
\hline ESJFP-09 & - & - & 0.4 & 5 & 18.7 & Oxic & - \\
\hline ESJFP-10 & - & 1.37 & 0.2 & 6 & 16.1 & Oxic & $\mathrm{O}_{2}$ ? OrNO 3 \\
\hline TRCYFP-01 & - & 0.06 & 2,480 & 1,240 & 62.9 & Anoxic & $\mathrm{Fe}(\mathrm{III}) / \mathrm{SO}_{4}-\mathrm{O}_{2} ?$ \\
\hline TRCYFP-02 & - & 1.69 & 0.2 & 3 & 252 & Oxic & $\mathrm{O}_{2}$ ? OrNO 3 \\
\hline TRCYFP-03 & - & - & 1.9 & 9 & 223 & Oxic & - \\
\hline TRCYFP-04 & - & 1.86 & 1.5 & 15 & 309 & Oxic & $\mathrm{O}_{2}$ ? $\mathrm{OrNO}_{3}$ \\
\hline TRCYFP-05 & - & - & 2.1 & 6 & 244 & Oxic & - \\
\hline
\end{tabular}

${ }^{1}$ Samples with two sample identification numbers identify those samples for which concentrations of nitrate plus nitrite (as nitrogen) were obtained from the California Department of Public Health database and all other results are from USGS-GAMA. 


\section{Appendix C. Calculating Total Dissolved Solids}

Data for specific conductance (SC), an electrical measure of total dissolved solids (TDS), were available for all 61 USGS-grid and understanding wells, whereas measured TDS data were available only for 33 USGS-grid and understanding wells. For wells that had no measured TDS, TDS was estimated from $\mathrm{SC}$ values using a linear regression equation
(TDS $=0.6973 * \mathrm{SC}-9.87)$ derived from the comparison of TDS and SC values obtained from the 33 USGS-GAMA wells having SC and TDS data in the Northern San Joaquin Basin study unit (method described by Hem, 1992). The resulting regression equation had a coefficient of determination $\left(\mathrm{r}^{2}\right)$ value of 0.989 . 


\section{Appendix D. Comparison of CDPH and USGS-GAMA Data}

CDPH and USGS-GAMA data were compared to assess the validity of using data from these different sources in combination. Because laboratory reporting levels (LRLs or MDLs), generally defined as the level at which a constituent can be reliably be detected, for most organic constituents and trace elements were substantially lower for USGSGAMA data than for CDPH data (table 2), it was not possible to directly compare concentrations of these constituent types in individual wells in any meaningful way. However, concentrations of major ions and nitrate, which generally are prevalent and have concentrations well above reporting levels, could be compared for those wells with data from both sources.

Seventeen wells had some data for major ions and nitrate in common between the datasets. The small number of wells prevented a statistically robust analysis for each individual constituent. However, the paired analyses for eight constituents (calcium, magnesium, sodium, alkalinity, chloride, sulfate, TDS, nitrate-N) with concentrations greater than the reporting levels in both data bases were combined into one dataset so that there was a sufficiently large dataset (126 pairs) for meaningful statistical comparison (fig. D1).

The Wilcoxon rank-sum test indicated no significant differences between the paired datasets $(z=0.05, p=0.95)$. Although differences between the paired data sets occurred for a few wells, most sample pairs plotted close to a 1 to 1 line (fig. D1). The relative percent difference (RPD) was calculated for each data pair. The median RPD was 6.8 percent and nearly 80 percent of the RPD values were less than 20 percent. These direct comparisons indicated that the USGS-GAMA and CDPH inorganic constituent data were not significantly different.

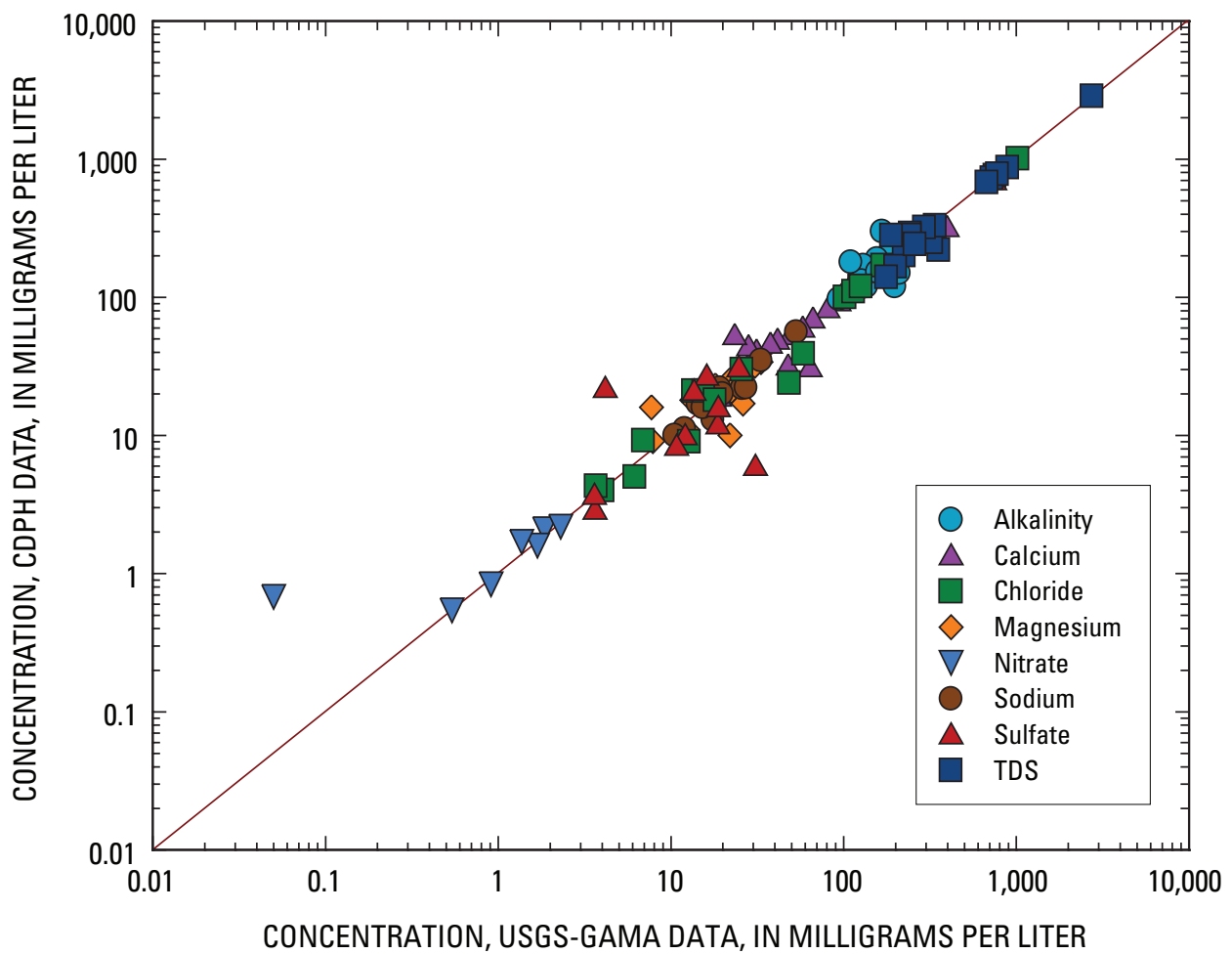

Figure D1. Graph of paired inorganic concentrations from wells sampled by the Groundwater Ambient Monitoring and Assessment (GAMA) Program between December 2004 and February 2005 and the most recent available analysis in the California Department of Health Services for the same wells, Northern San Joaquin Basin Groundwater Ambient Monitoring and Assessment (GAMA) study unit. 
Trilinear diagrams commonly are used to define groundwater type (Hem, 1992). Trilinear diagrams illustrate the relative contributions of major cations and anions (on a charge-equivalent basis) as a percentage of the total ion content of the water (fig. D2). Combined USGS-GAMA and CDPH major ion data for grid wells were plotted on trilinear diagrams (Piper, 1944) along with all CDPH major ion data. This was done to determine whether the groundwater types observed in grid wells were similar to groundwater types observed historically in the study unit. All recent (January 1, 2001-April 21, 2004) CDPH data having cation/anion data and a cation/anion balance within 10 percent were retrieved and plotted on the trilinear diagrams for comparison with grid-well data.
Data from grid wells and recent CDPH data indicate that a similar range of water types was sampled (fig. D2). At most wells, no single cation accounted for more than 60 percent of the total cations, and bicarbonate accounted for more than 60 percent of the total anions; these samples are described as mixed cation-bicarbonate type waters. At many other wells, no single cation and no single anion accounted for more than 60 percent of the total; these samples are described as mixed cation-mixed anion type waters. In a minority of wells, sodium and chloride accounted for more than 60 percent of the total cations and anions, respectively; these samples are classified as sodium-chloride type waters. The similarity of the range of relative abundance of major cations and anions in grid wells to those in the set of all CDPH wells indicates that the grid wells represent the distribution and diversity of water types present in the Northern San Joaquin Basin study unit.

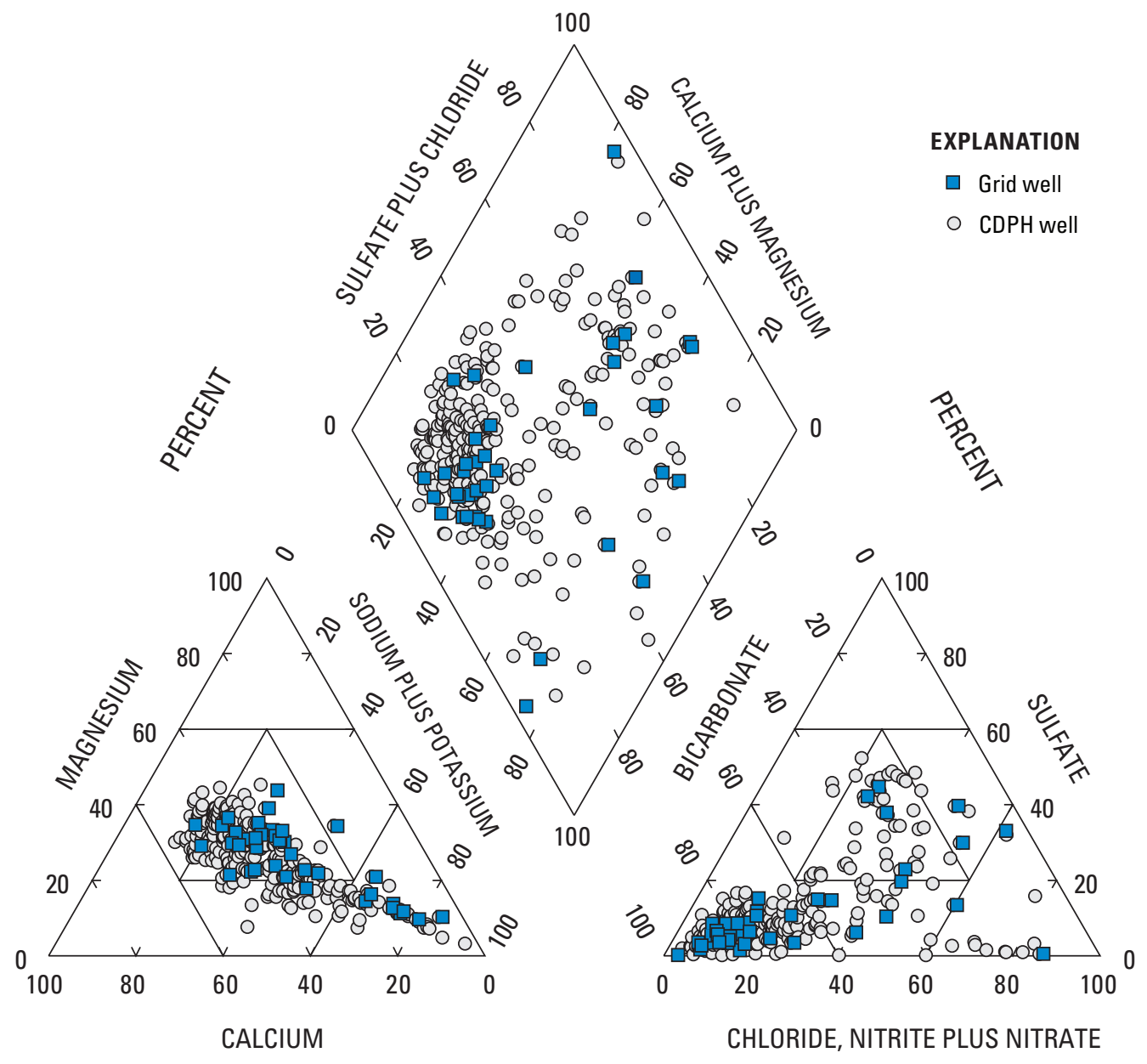

PERCENTAGE OF TOTAL, IN MILLIEQUVALENTS PER LITER

Figure D2. Trilinear diagram comparing water types in grid wells with water types in all wells in the California Department of Public Health (CDPH) database that have a charge imbalance of less than 10 percent, Northern San Joaquin Basin Groundwater Ambient Monitoring and Assessment (GAMA) study unit. 
Publishing support provided by the U.S. Geological Survey

Publishing Network, Sacramento and Tacoma Publishing Service Center

For more information concerning the research in this report, contact the Director, California Water Science Center

U.S. Geological Survey

$6000 \mathrm{~J}$ Street

Sacramento, California 95819

http://ca.water.usgs.gov 
CALIFORNIA
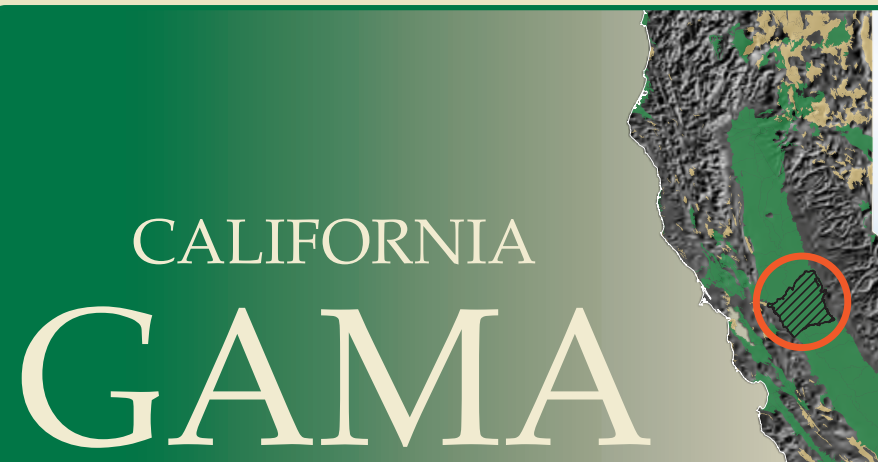

PROGRAM

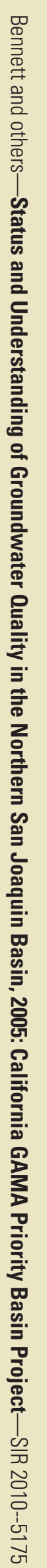

